\title{
24. PALEOMAGNETIC RESULTS, NANKAI TROUGH AND JAPAN TRENCH, DEEP SEA DRILLING PROJECT LEG $87^{1}$
}

\author{
Nobuaki Niitsuma, Institute of Geosciences, Shizuoka University²
}

\begin{abstract}
Paleomagnetic measurements of sediment samples provide the magnetostratigraphy at Deep Sea Drilling Sites 582, 583, and 584 in the Nankai Trough and the Japan Trench. Drastic changes in the rate of sediment accumulation are documented by the magnetostratigraphic and biostratigraphic correlations. The changes in the accumulation rate correspond to the supply of sediments and variations in the accretionary process, which are directly related to the tectonic cycles in the geologic evolution of the Japanese island arc. Faults and folds within the drilled sedimentary sequences are oriented by paleomagnetic declination. Their directions and stress patterns are related to the relative plate motion along the trough and trench. The original remanent magnetization of the sediment was modified and remagnetized in the tectonic process of accretion by physical deformation, faulting, and intrusion of dewatering veinlets.
\end{abstract}

\section{INTRODUCTION}

This chapter describes the results of a shipboard and shore-based paleomagnetic study of sediments recovered from the axis and inner slope of the Nankai Trough and from the inner slope of the Japan Trench during Leg 87 of the Deep Sea Drilling Project (Fig. 1). The purposes of this study are to obtain reliable paleomagnetic data, to establish the magnetostratigraphy of the drilled sediments, to determine attitudes of bedding and fault planes, and to deduce paleocurrent direction. These are some of the fundamental data for elucidating the tectonic evolution of the subduction zone.

\section{METHOD}

\section{Paleomagnetic Techniques}

Remanent magnetization of sediments was measured with a shipboard Digico balanced fluxgate rock magnetometer, and with a ringcore-type fluxgate spinner magnetometer of Shizuoka University (Koyama and Niitsuma, 1983). The noise level is 2 to $3 \times 10^{-4} \mathrm{~A} / \mathrm{m}$ for the Digico magnetometer and $5 \times 10^{-5} \mathrm{~A} / \mathrm{m}$ for the ring-core magnetometer.

Soft components of remanent magnetization of the samples were eliminated by alternating-field (AF) demagnetization, using the shipboard Schonstedt alternating-current, geophysical-specimen demagnetizer (Model GSD-1) and a current-regulated, three-axial AF demagnetizer (Koyama and Niitsuma, 1983). For demagnetization of every sample, the Schonstedt demagnetizer requires operation three times about three orthogonal axes, whereas the three-axial AF demagnetizer requires operation only once about all axes.

Initial susceptibility and anisotropy of susceptibility were measured with a ring-core-type fluxgate spinner magnetometer at Shizuoka University. A magnetic field of $25 \mu \mathrm{T}$ was supplied for the susceptibility measurement (Koyama and Niitsuma, 1983).

Natural remanent magnetization (NRM) of selected samples was measured, and samples with strong enough intensity (more than $5 \times$ $10^{-4} \mathrm{~A} / \mathrm{m}$ of NRM) were used for the AF demagnetization test with the shipboard magnetometer. Remanent magnetization of all samples was measured after AF demagnetization, and susceptibility was exam-

\footnotetext{
${ }^{1}$ Kagami, H., Karig, D. E., Coulbourn, w. T., et al., Init. Repts. DSDP, 87: Washington (U.S. Govt. Printing Office).

2 Address: Institute of Geosciences, Shizuoka University, 836 Oya, Shizuoka 422, Japan.
}

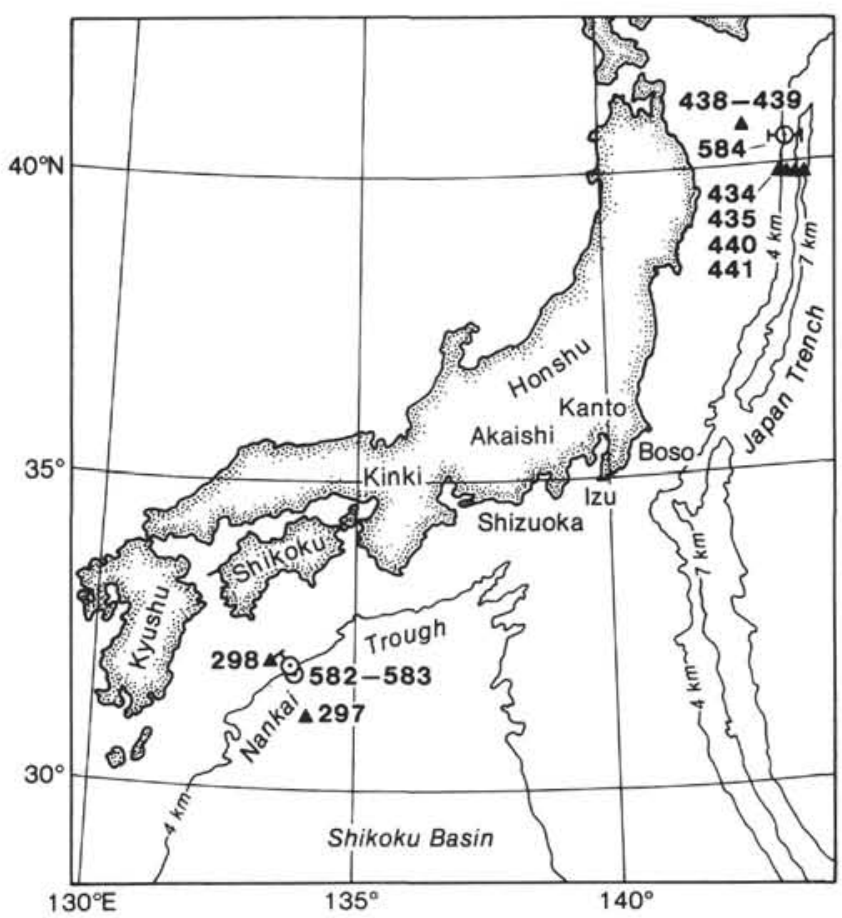

Figure 1. Location of Leg 87 Sites.

ined on samples with intensities greater than $5 \times 10^{-4} \mathrm{~A} / \mathrm{m}$ after AF demagnetization at $15 \mathrm{mT}$.

\section{Sampling Procedure}

Paleomagnetic samples were taken from unconsolidated and semiconsolidated sediments using a $2.2-\mathrm{cm}^{3}$ plastic box inserted vertically into the split faces of the upper sections of each core. For consolidated sediment at deeper levels, cylindrical samples of $2.5-\mathrm{cm}$ diameter were taken through the split cores with a shipboard diamond corer. At least one sample was taken from each section, and more than one sample was taken from the sections of sedimentologic and tectonic interest, especially from hydraulic piston cores. Drilling disturbance or faults were carefully avoided in the selection of paleomagnetic samples. Samples from Hole 582 and Holes $583 \mathrm{~A}$ through $583 \mathrm{~F}$ were taken by $\mathrm{A}$. Taira, and those from Hole 583G and Holes 584 through 584B were collected by the author. The inclinations of faults and bedding planes were measured against the split plane. 


\section{Stability Test of Sediments by AF Demagnetization}

The first step in a paleomagnetic study is to eliminate any magnetic overprint from the natural remanent magnetization. Sediments acquire a "soft" component of remanent magnetization after deposition, mostly in the present geomagnetic field, even in the course of drilling and sample treatment. The amounts and properties of the soft component are ascribed to the grain type and size of the magnetic mineral. Usually the soft component is carried by magnetic minerals with multi-magnetic domains. In the case of magnetite, grains are larger than 5-10 $\mu \mathrm{m}$ across. The proportion of the soft component can indicate the sediment type. Because AF demagnetization is effective for eliminating the soft component of remanent magnetization, it is also a check for the reliability of remanent magnetization.

The stepwise AF demagnetization was made on the selected samples from each site, and the changes in angle and intensity for the pilot samples were recorded (Fig. 2). In most cases, the median destructive field (MDF) (intensity of alternating field to demagnetize the initial NRM intensity by half) is higher than $20 \mathrm{mT}$, except for three pilot samples with MDFs of 8,10 , and $13 \mathrm{mT}$, values higher than usual for sedimentary rocks. Changes in direction of more than $10^{\circ}$ occur in the steps between 0 and $5 \mathrm{mT}$, and between 10 and $15 \mathrm{mT}$, and those of less than $7^{\circ}$ occur in the steps between 15 and $20 \mathrm{mT}$. The result shows two types of soft-component remanent magnetization, and both components can be removed with the AF demagnetization at $15 \mathrm{mT}$. I selected the demagnetization field of $15 \mathrm{mT}$ to eliminate the soft components of NRM of al__samples. The small change after AF demagnetization means that the magnetic minerals in the measured samples are small enough to carry the stable remanent magnetization and that the drill sites were far enough from the source of the sediments for sorting of the magnetic minerals during transportation.

\section{RESULTS}

\section{Site $\mathbf{5 8 2}$}

Bedding planes are almost horizontal at this site. The maximum dip measured is less than $15^{\circ}$ in the lower part of the sedimentary section, and no correction is made for tilting of the sediments. The intensity of remanent magnetization of the 234 samples examined is of the order $10^{-2} \mathrm{~A} / \mathrm{m}$ after $15 \mathrm{mT} \mathrm{AF}$ demagnetization, except below $630 \mathrm{~m}$ sub-bottom depth and in the uppermost part above $20 \mathrm{~m}$ sub-bottom (Fig. 3, Table 1). The intensity is controlled by sediment provenance. Turbidites have high and hemipelagic muds have low intensities. The low intensity recorded for sediments below $630 \mathrm{~m}$ sub-bottom is due to their depositional environment in the Shikoku Basin, far from the turbidite regime of the Nankai Trough axis. Low intensity, less than $10^{-3} \mathrm{~A} / \mathrm{m}$, of the uppermost part cannot be explained in this way; possibly the source area of these sediments has changed tectonically.

A bimodal frequency pattern of the inclinations of normal and reversed geocentric axial dipole field for this area $\left( \pm 51.3^{\circ}\right)$ allows magnetostratigraphic correlation of the sediments (Figs. 3, 4). The boundary between the Brunhes and Matuyama magnetic polarity epochs is at $607 \mathrm{~m}$ sub-bottom, and a normal-polarity interval between 662 and $693 \mathrm{~m}$ correlates with the Jaramillo Normal Magnetic Polarity Event. Three horizons with reversed polarity were found at $28.42,106.67$, and $288.00 \mathrm{~m}$ sub-bottom, in the Brunhes Epoch (Fig. 3). These horizons may match short events, such as the Blake; Biwa I, II, and III; and Emperor events. The biostratigraphic data help in matching reversals to these events. The last occurrence of Pseudoemiliania lacunosa (boundary of $\mathrm{CN} \mathrm{14b/a)} \mathrm{is} \mathrm{at} 89.25 \mathrm{~m}$ sub-bottom (Lang, this volume), a horizon correlatable with oxygen isotope Stage
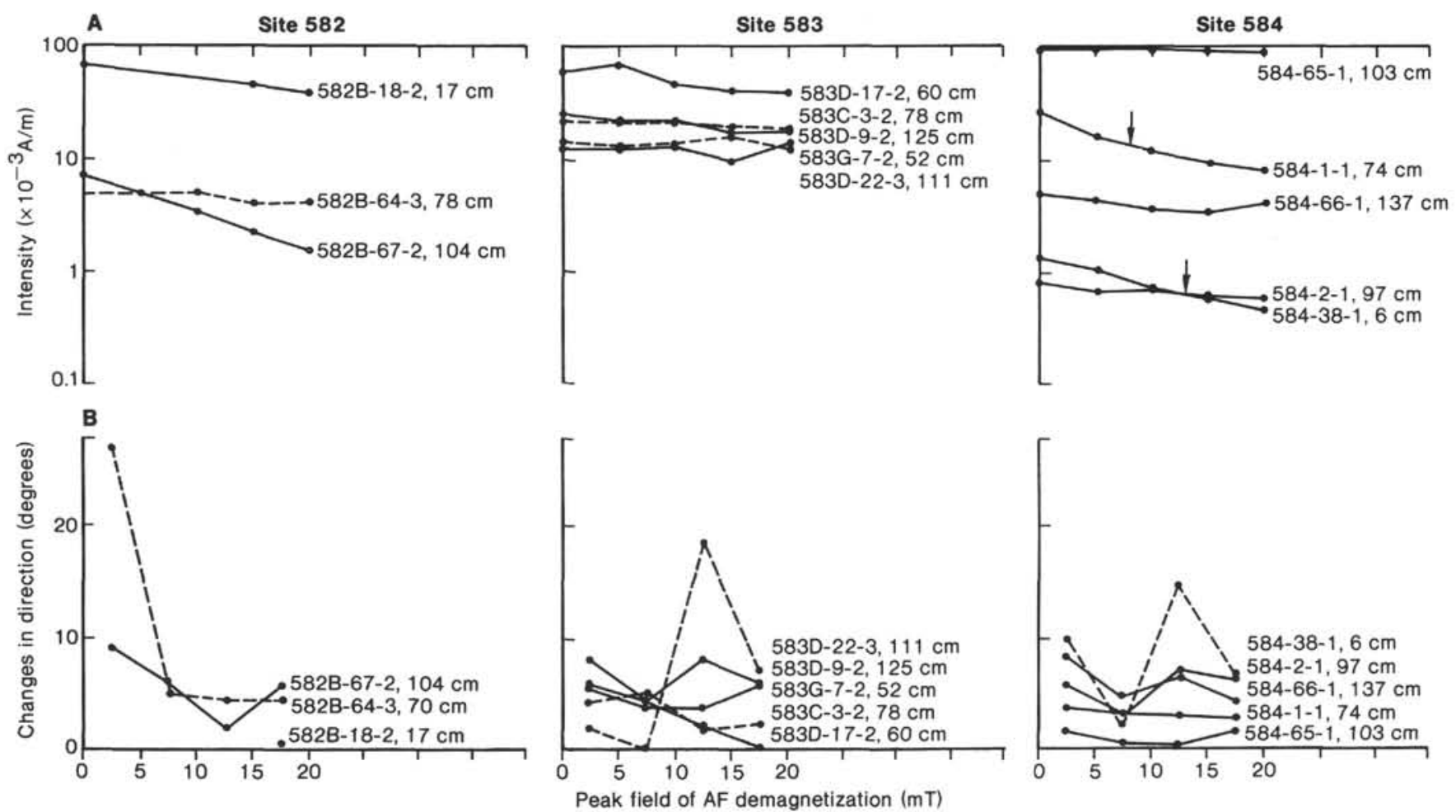

Figure 2. Reaction of remanent magnetization of sediment samples during stepwise alternating-field (AF) demagnetization. A. Changes in intensity of remanent magnetization (logarithmic scale). B. Changes in direction of remanent magnetization with each AF demagnetization step. Arrows represent median destructive field (MDF). 


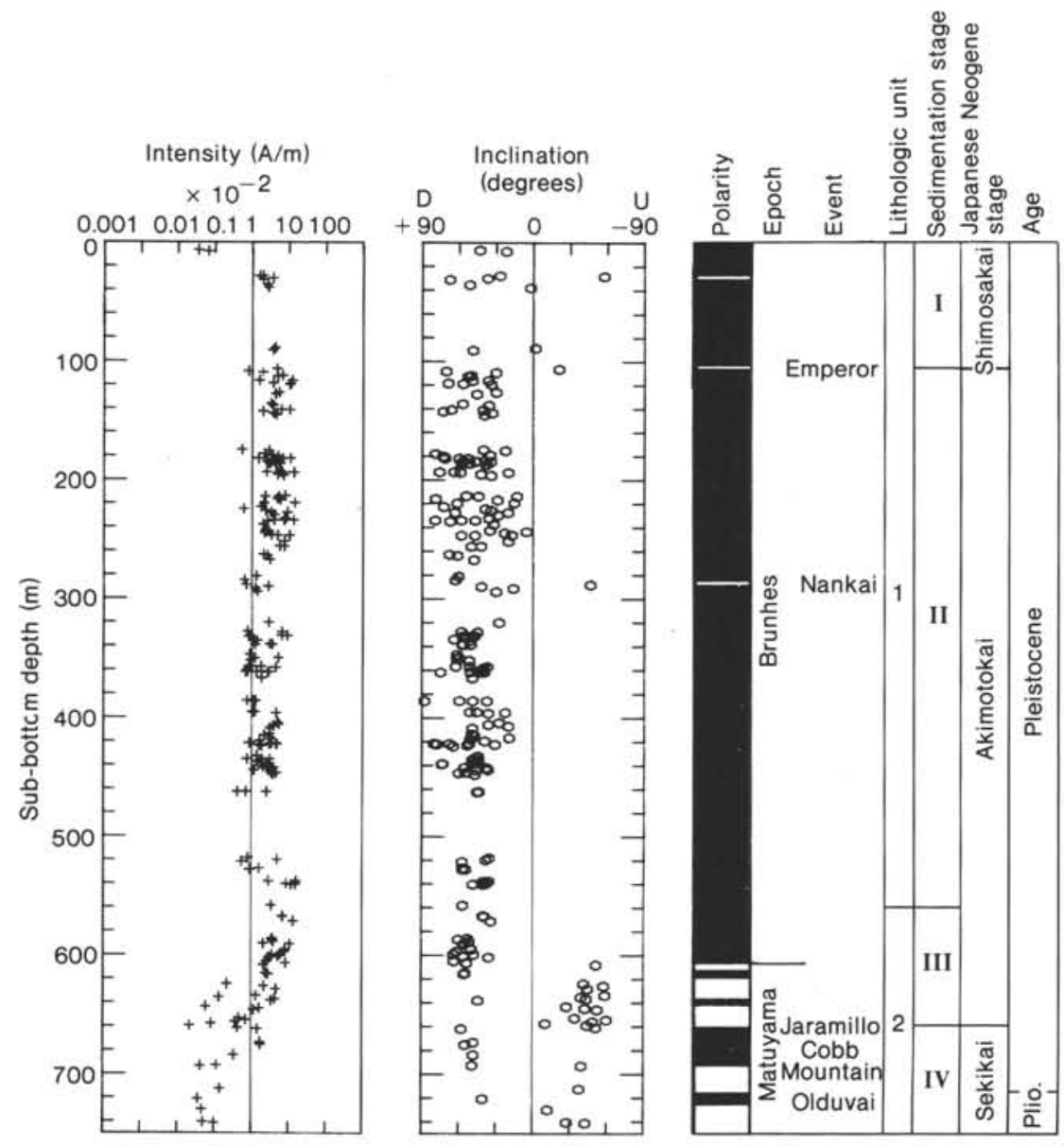

Figure 3. Magnetostratigraphy of Site 582 and correlation with the Japanese Neogene stages. Measurements by a ring-core-type fluxgate spinner magnetometer after 15-mT AF demagnetization.

12, dated as $0.44 \mathrm{Ma}$ (Gartner and Emiliani, 1976). The second reversal at Site 582 probably correlates with the Emperor Event, which corresponds to oxygen isotope Stage $13 / 14$ and an estimated age of $0.52 \mathrm{Ma}$, by the zone-magnetization model of isotope stratigraphy and magnetic intensity data (Wollin et al., 1971; Niitsuma, 1977). The lower reversal is an unreported event, referred to as the Nankai Reversed Magnetic Polarity Event in this report.

Two normal-polarity horizons are found in the upper part of the Matuyama Reversed Polarity Epoch above the Jaramillo Event. These events have been reported in the Choshi Peninsula (Koizumi and Kanaya, 1976) and in deep-sea sediment B21-2 (Niitsuma and $\mathrm{Ku}, 1977$ ). Beneath the Jaramillo Event, the occurrence of nannoplankton marks the $\mathrm{CN} 12 / 13$ boundary at $713 \mathrm{~m}$ subbottom and the normal-polarity Olduvai Event at $720 \mathrm{~m}$. Below this horizon, polarity is reversed, and this hole did not reach the boundary between the Matuyama and Gauss epochs (2.48 Ma).

On the basis of the ages of these magnetostratigraphic horizons, the sediment accumulation rate is $200 \mathrm{~m} / \mathrm{Ma}$ between the top of $89.25 \mathrm{~m}$ sub-bottom and $210 \mathrm{~m} / \mathrm{Ma}$ between 89.25 and $106.7 \mathrm{~m}$. The sediments between 106.7 and $607 \mathrm{~m}$ accumulated at $2380 \mathrm{~m} / \mathrm{Ma}$, an order of magnitude faster than at the top of the hole; however, the lithologic facies boundary between Unit 1 and Unit 2 is within this interval-at $566 \mathrm{~m}$ sub-bottom depth. Unit 1 is an alternation of hemipelagic mud and turbidites; Unit 2 is hemipelagic mud. Because turbidites are deposited instantaneously and hemipelagic mud uniformly, the calculated rate probably underestimates the former and overestimates the latter. If we accept a constant accumulation rate for the hemipelagic mud in Units 1 and 2 and consider the proportion of the thickness of hemipelagic mud $(18 \%)$ and turbidites $(82 \%)$ in Unit 1 , then the rate is $600 \mathrm{~m} / \mathrm{Ma}$ for Unit 2, the lithologic boundary is dated at $0.65 \mathrm{Ma}$, and the rate for the alternating sequence in Unit 1 is $3530 \mathrm{~m} / \mathrm{Ma}$.

The rate of accumulation from the top of the Jaramillo $(0.92 \mathrm{Ma})$ to the Brunhes-Matuyama boundary $(0.73 \mathrm{Ma})$ is $290 \mathrm{~m} / \mathrm{Ma}$, but the rate during the Jaramillo Event is calculated as $620 \mathrm{~m} / \mathrm{Ma}$ by the correlation already mentioned. The rate for the interval between the top of the Jaramillo and Olduvai events is $90 \mathrm{~m} / \mathrm{Ma}$, which is almost the same as the rate of $100 \mathrm{~m} / \mathrm{Ma}$ for the interval from the Olduvai Event to the Matuyama/ Gauss boundary. The rate for the Jaramillo Event is ex- 
Table 1. Paleomagnetic measurements after 15-mT AF demagnetization at Site 582 .

\begin{tabular}{|c|c|c|c|c|c|}
\hline $\begin{array}{l}\text { Core-Section } \\
\text { (interval in } \mathrm{cm} \text { ) }\end{array}$ & $\begin{array}{l}\text { Sub-bottom } \\
\text { depth (m) }\end{array}$ & $\begin{array}{c}\text { Intensity } \\
\left(\times 10^{-3} \mathrm{~A} / \mathrm{m}\right)\end{array}$ & $\begin{array}{c}\text { Relative } \\
\text { decl. } \\
\text { (degrees) }\end{array}$ & $\begin{array}{c}\text { Incl. } \\
\text { (degrees) }\end{array}$ & $\begin{array}{c}\text { Error } \\
\text { in incl. } \\
\text { (degrees) }\end{array}$ \\
\hline
\end{tabular}

Hole 582

$\begin{array}{lrrrrr}1-5,52-54 & 6.53 & 0.52 & 323.8 & 38.8 & 9.2 \\ 1-6,7-9 & 7.58 & 0.87 & 324.8 & 30.5 & 2.6 \\ 3-6,120-122 & 28.11 & 20.21 & 40.8 & 27.0 & 3.1 \\ 3, \mathrm{CC}(1-3) & 28.42 & 16.57 & 29.1 & -50.8 & 1.6\end{array}$

Hole $582 \mathrm{~A}$

$\begin{array}{lrrrrr}2-1,120-122 & 30.31 & 35.47 & 181.0 & 43.4 & 0.5 \\ 2-2,77-79 & 31.38 & 20.10 & 49.0 & 67.6 & 0.7 \\ 2-5,72-74 & 35.83 & 26.09 & 60.8 & 51.5 & 1.9 \\ 2-7.11-13 & 38.22 & 28.49 & 120.1 & 2.3 & 0.3\end{array}$

Hole 582B

\begin{tabular}{|c|c|c|c|c|c|}
\hline $5-2,18-20$ & 88.99 & 43.64 & 140.8 & -1.7 & 0.4 \\
\hline $5-3,67-69$ & 90.98 & 37.52 & 153.5 & 48.7 & 0.7 \\
\hline $7-1,16-18$ & 106.67 & 47.74 & 97.8 & -21.0 & 0.4 \\
\hline $7-2,60-62$ & 108.61 & 8.19 & 71.7 & 70.4 & 3.4 \\
\hline $7-3,16-18$ & 109.67 & 20.23 & 90.7 & 30.0 & 0.2 \\
\hline $7-4,122-124$ & 112.23 & 68.93 & 134.2 & 50.2 & 1.5 \\
\hline $7-5,50-52$ & 113.01 & 55.92 & 109.6 & 50.0 & 1.3 \\
\hline $8-1,34-36$ & 116.45 & 125.79 & 75.7 & 36.1 & 1.3 \\
\hline $7-7,104-106$ & 116.55 & 16.13 & 211.8 & 49.1 & 0.9 \\
\hline $8-2,111-113$ & 118.72 & 38.26 & 227.8 & 68.8 & 1.1 \\
\hline $8-3,10-12$ & 119.21 & 114.76 & 0.5 & 56.6 & 0.5 \\
\hline $8-3,59-61$ & 119.70 & 107.23 & 170.9 & 33.9 & 0.9 \\
\hline $9-1,60-62$ & 126.41 & 55.10 & 291.9 & 29.8 & 2.2 \\
\hline $9-2,55-57$ & 127.86 & 44.65 & 249.9 & 45.4 & 1.4 \\
\hline $10-1,57-59$ & 136.08 & 33.40 & 53.4 & 57.0 & 1.2 \\
\hline $10-2,38-40$ & 137.39 & 38.73 & 121.0 & 35.8 & 1.6 \\
\hline $10-4,106-108$ & 141.07 & 62.72 & 130.8 & 66.3 & 1.8 \\
\hline $10-4,136-138$ & 141,37 & 107.90 & 336.2 & 40.5 & 0.6 \\
\hline $10-5,109-111$ & 142.60 & 20.24 & 130.4 & 72.8 & 2.2 \\
\hline $10-6,99-101$ & 144.00 & 38.60 & 249.8 & 33.2 & 2.3 \\
\hline $12-1,83-85$ & 145.64 & 46.04 & 254.2 & 39.4 & 1.9 \\
\hline $14-1,94-96$ & 174.95 & 5.41 & 333.8 & 40.2 & 1.0 \\
\hline $14-2,18-20$ & 175.69 & 29.51 & 327.7 & 22.5 & 0.5 \\
\hline $14-3,137-139$ & 178.38 & 22.08 & 119.0 & 79.2 & 2.2 \\
\hline $14-4,89-91$ & 179.40 & 35.49 & 197.4 & 34.9 & 1.7 \\
\hline $14-5,32-34$ & 180.33 & 51.13 & 5.1 & 72.9 & 1.1 \\
\hline $14-6,66-68$ & 182.17 & 111.73 & 328.6 & 59.9 & 1.4 \\
\hline $14-6,70-72$ & 182.21 & 15.17 & 228.4 & 71.4 & 0.4 \\
\hline $14-6,75-77$ & 182.26 & 69.00 & 203.7 & 52.9 & 1.8 \\
\hline $15-1,59-61$ & 184.20 & 34.67 & 240.0 & 39.1 & 2.2 \\
\hline $15-1,83-85$ & 184.44 & 45.44 & 257.9 & 56.6 & 2.2 \\
\hline $15-1,106-108$ & 184.67 & 42.18 & 315.9 & 46.2 & 1.3 \\
\hline $15-1,133-135$ & 184.94 & 25.64 & 187.5 & 34.3 & 1.6 \\
\hline $15-2,128-130$ & 186.39 & 58.10 & 167.6 & 51.4 & 0.9 \\
\hline $15-2,135-137$ & 186.46 & 30.59 & 227.4 & 58.0 & 2.0 \\
\hline $15-3,55-57$ & 187.16 & 45.83 & 229.7 & 37.7 & 1.0 \\
\hline $16-1,30-32$ & 193.51 & 55.23 & 2.6 & 64.1 & 0.4 \\
\hline $16-1,38-40$ & 193.59 & 25.17 & 306.6 & 75.7 & 2.6 \\
\hline $16-1,73-75$ & 193.94 & 66.29 & 85.5 & 58.8 & 2.0 \\
\hline $16-1,87-89$ & 194.08 & 137.07 & 241.4 & 20.1 & 2.1 \\
\hline $16-2,72-74$ & 195.43 & 49.66 & 257.9 & 42.3 & 1.0 \\
\hline $16-3,33-35$ & 196.54 & 72.43 & 324.7 & 34.0 & 0.7 \\
\hline $18-1,115-118$ & 213.67 & 79.33 & 308.9 & 54.3 & 1.3 \\
\hline $18-2,10-12$ & 214.11 & 22.98 & 15.6 & 44.4 & 1.4 \\
\hline $18-2,16-18$ & 214.17 & 53.35 & 213.9 & 13.2 & 2.1 \\
\hline $18-3,70-72$ & 216.21 & 48.90 & 78.9 & 79.0 & 2.5 \\
\hline $18-4,26-28$ & 217.27 & 58.98 & 302.5 & 29.0 & 2.3 \\
\hline $18-5,116-118$ & 219.67 & 144.92 & 46.8 & 15.4 & 3.0 \\
\hline $18-5,141-143$ & 219.92 & 20.99 & 223.5 & 61.6 & 1.9 \\
\hline $19-1,76-78$ & 222.97 & 17.85 & 254.7 & 72.3 & 0.7 \\
\hline $19-2,107-109$ & 224.78 & 5.96 & 229.8 & 38.7 & 2.1 \\
\hline $19-3,98-100$ & 226.19 & 23.61 & 61.0 & 33.9 & 2.6 \\
\hline $19-4,103-105$ & 227.74 & 33.58 & 107.3 & 20.3 & 1.8 \\
\hline $19-4,110-112$ & 227.81 & 91.47 & 182.7 & 63.4 & 1.1 \\
\hline $19, \mathrm{CC}(21-23)$ & 229.92 & 40.87 & 274.2 & 28.5 & 0.8 \\
\hline $20-1,102-104$ & 232.93 & 82.03 & 315.5 & 35.6 & 0.9 \\
\hline $20-2,91-93$ & 234.32 & 73.02 & 80.4 & 58.2 & 1.2 \\
\hline $20-2,91-93$ & 234.32 & 133.78 & 145.0 & 79.4 & 0.9 \\
\hline $20-2,100-102$ & 234.41 & 39.37 & 254.0 & 47.0 & 1.3 \\
\hline $20-3,28-30$ & 235.19 & 26.00 & 113.2 & 67.4 & 1.2 \\
\hline $20-4,141-143$ & 237.82 & 19.70 & 228.0 & 32.1 & 1.2 \\
\hline $21-1,131-133$ & 242.82 & 23.36 & 85.3 & 35.0 & 1.3 \\
\hline $21-2,85-87$ & 243.86 & 28.67 & 283.3 & 5.4 & 1.1 \\
\hline $21-3,55-57$ & 245.06 & 21.97 & 346.3 & 23.1 & 0.4 \\
\hline $21-4,83-85$ & 246.84 & 33.74 & 23.6 & 17.4 & 0.3 \\
\hline $21, \mathrm{CC}(1-3)$ & 247.02 & 49.60 & 220.8 & 58.2 & 0.8 \\
\hline $21, C C(7-9)$ & 247.08 & 103.67 & 33.0 & 47.2 & 1.3 \\
\hline $22-1,103-105$ & 252.14 & 75.01 & 215.2 & 20.0 & 0.6 \\
\hline $22-4,67-69$ & 256.28 & 56.67 & 102.9 & 42.1 & 1.2 \\
\hline $22-4,77-79$ & 256.38 & 74.84 & 182.9 & 50.1 & 0.5 \\
\hline $23-2,89-91$ & 263.10 & 20.68 & 8.2 & 67.9 & 0.6 \\
\hline $23-3,35-37$ & 264.06 & 25.98 & 33.9 & 61.3 & 2.9 \\
\hline $23-5,91-93$ & 267.62 & 30.62 & 55.5 & 47.9 & 1.5 \\
\hline
\end{tabular}

Table 1. (Continued).

\begin{tabular}{cccccc}
\hline $\begin{array}{c}\text { Core-Section } \\
\text { (interval in cm) }\end{array}$ & $\begin{array}{c}\text { Sub-bottom } \\
\text { depth }(\mathrm{m})\end{array}$ & $\begin{array}{c}\text { Intensity } \\
\left(\times 10^{-3} \mathrm{~A} / \mathrm{m}\right)\end{array}$ & $\begin{array}{c}\text { Relative } \\
\text { decl. } \\
(\text { degrees })\end{array}$ & $\begin{array}{c}\text { Incl. } \\
\text { (degrees) }\end{array}$ & $\begin{array}{c}\text { Error } \\
\text { in incl. } \\
\text { (degrees) }\end{array}$ \\
\hline Hole 582B (Cont.) & & &
\end{tabular}

$\begin{array}{rrrrrr}25-1.145-147 & 281.36 & 13.07 & 324.4 & 60.4 & 1.0\end{array}$

$\begin{array}{llllll}25-4,14-16 & 284.55 & 6.32 & 31.1 & 62.8 & 0.5\end{array}$

$\begin{array}{lrrrrr}25 . C C(49-51) & 288.40 & 7.07 & 99.4 & -46.7 & 2.1 \\ 26-1,50-52 & 290.01 & 28.31 & 310.5 & 41.7 & 0.6\end{array}$

$\begin{array}{llllll}26-1,50-52 & 290.01 & 28.31 & 310.5 & 41.7 & 0.6 \\ 26-2,50-52 & 291.51 & 12.31 & 158.8 & 15.9 & 1.6\end{array}$

$\begin{array}{llllll}26-4.32-34 & 294.33 & 14.29 & 259.7 & 29.8 & 1.3\end{array}$

$\begin{array}{lrrrrr}29-2,50-52 & 320.31 & 29.11 & 22.9 & 27.3 & 0.2 \\ 30-1,5-7 & 327.96 & 7.73 & 183.6 & 57.8 & 1.0\end{array}$

$\begin{array}{llllll}30-1,43-45 & 328.34 & 65.89 & 275.2 & 44.6 & 1.9\end{array}$

$\begin{array}{llllll}30-3,54-56 & 331.45 & 64.80 & 267.4 & 47.0 & 1.5 \\ 30-3.68-70 & 331.59 & 92.37 & 310.5 & 56.6 & 1.5\end{array}$

$\begin{array}{rrrrrr}30-3,68-70 & 331.59 & 92.37 & 310.5 & 56.6 & 1.5 \\ 30-3,97-99 & 331.88 & 9.10 & 114.8 & 49.2 & 1.0\end{array}$

$\begin{array}{lrrrrr}30-4.7-9 & 332.18 & 8.35 & 121.0 & 53.2 & 1.4 \\ 30-5,65-67 & 334.26 & 10.87 & 51.3 & 63.8 & 1.3\end{array}$

$\begin{array}{rrrrrr}30-6,57-59 & 335.68 & 14.16 & 242.6 & 51.1 & 1.7\end{array}$

$\begin{array}{llllll}31-1,96-98 & 338.47 & 30.52 & 90.0 & 57.1 & 1.9 \\ 31-1,126-128 & 338.77 & 36.45 & 72.3 & 50.2 & 1.8\end{array}$

$\begin{array}{rrrrrr}31-1,137-139 & 338.88 & 12.44 & 254.1 & 56.2 & 1.6\end{array}$

$\begin{array}{lrrrrr}32-1,17-19 & 347.28 & 8.77 & 171.4 & 61.6 & 0.4 \\ 32-3.3-5 & 350.14 & 52.28 & 165.8 & 59.6 & 1.2\end{array}$

$\begin{array}{llllll}32-3,3-5 & 350.14 & 52.28 & 165.8 & 59.6 & 1.2 \\ 32-3,15-17 & 350.26 & 12.50 & 154.4 & 61.6 & 1.7\end{array}$

$\begin{array}{rrrrrr}32-3,15-17 & 350.26 & 12.50 & 154.4 & 61.6 & 1.7 \\ 32-4,53-55 & 352.14 & 9.06 & 60.2 & 51.4 & 1.4\end{array}$

$\begin{array}{rrrrrr}33-1,58-60 & 357.09 & 8.38 & 198.3 & 62.4 & 1.8 \\ 33-1,66-68 & 357.17 & 10.12 & 199.1 & 51.1 & 1.9\end{array}$

$\begin{array}{llllll}33-1,66-68 & 357.17 & 10.12 & 199.1 & 51.1 & 1.9 \\ 33-1,77-79 & 357.28 & 17.90 & 323.6 & 36.7 & 1.1\end{array}$

$\begin{array}{rrrrrr}33-2,10-12 & 358.11 & 45.48 & 192.4 & 39.4 & 1.0 \\ 33-3.22-24 & 359.73 & 7.81 & 255.7 & 41.6 & 0.7\end{array}$

$\begin{array}{llllll}33-3,22-24 & 359.73 & 7.81 & 255.7 & 41.6 & 0.7 \\ 33-4,55-57 & 361.56 & 6.73 & 267.1 & 44.2 & 1.5\end{array}$

$\begin{array}{llllll}33-4,55-57 & 361.56 & 6.73 & 267.1 & 44.2 & 1.5 \\ 33-4,58-60 & 361.59 & 7.72 & 280.0 & 50.3 & 1.1\end{array}$

$\begin{array}{llllll}33-4,66-68 & 361.67 & 13.50 & 156.1 & 42.1 & 1.3 \\ 33-4,90-92 & 361.91 & 29.37 & 281.2 & 39.1 & 0.9\end{array}$

$\begin{array}{llrrrr}33-4,90-92 & 361.91 & 29.37 & 281.2 & 39.1 & 0.9 \\ 33-4,95-97 & 361.96 & 27.37 & 27.1 & 74.8 & 1.3\end{array}$

$\begin{array}{rrrrrr}34-1,94-96 & 366.85 & 18.78 & 49.5 & 48.9 & 1.1 \\ 36-1,95-97 & 385.76 & 7.47 & 220.0 & 59.3 & 1.0\end{array}$

$\begin{array}{llllll}36-1,104-106 & 385.85 & 12.89 & 234.5 & 48.6 & 0.8\end{array}$

$\begin{array}{llllll}36-1,114-116 & 385.95 & 11.53 & 90.7 & 37.2 & 2.0\end{array}$

$\begin{array}{llllll}36-1,121-123 & 386.02 & 11.38 & 238.3 & 87.6 & 1.5 \\ 37-1,101-103 & 395.32 & 12.34 & 264.4 & 50.8 & 1.5\end{array}$

$\begin{array}{rrrrrr}37-1,101-103 & 395.32 & 12.34 & 264.4 & 50.8 & 1.5 \\ 37-1,111-113 & 395.42 & 10.44 & 90.8 & 45.4 & 1.4\end{array}$

$\begin{array}{lrrrrr}37-1,137-139 & 395.68 & 11.00 & 83.7 & 22.4 & 1.5 \\ 37-2,50-52 & 396.31 & 45.80 & 282.5 & 36.0 & 1.2\end{array}$

$\begin{array}{llllll}37-2,50-52 & 396.31 & 45.80 & 282.5 & 36.0 & 1.2 \\ 38-1,36-38 & 404.17 & 49.79 & 190.6 & 27.4 & 0.5\end{array}$

$\begin{array}{rrrrrr}38-2,46-48 & 405.77 & 55.28 & 240.5 & 36.0 & 1.0 \\ 38-3.31-33 & 407.12 & 38.55 & 39.3 & 19.8 & 1.0\end{array}$

$\begin{array}{rrrrrr}38-3,31-33 & 407.12 & 38.55 & 39.3 & 19.8 & 1.0 \\ 38-4,54-56 & 408.85 & 31.44 & 253.0 & 49.0 & 1.1\end{array}$

$\begin{array}{llllll}38-4.54-56 & 408.85 & 31.44 & 253.0 & 49.0 & 1.1 \\ 39-1,63-65 & 413.84 & 30.38 & 112.0 & 49.5 & 0.9\end{array}$

$\begin{array}{llllll}39-2,47-49 & 415.18 & 21.81 & 226.8 & 47.5 & 1.3 \\ 39-3,68-70 & 416.89 & 30.66 & 137.3 & 19.3 & 0.5\end{array}$

$\begin{array}{llllll}39-4,30-32 & 418.01 & 32.87 & 323.8 & 50.3 & 0.8\end{array}$

$\begin{array}{rrrrrr}39-5,35-37 & 419.56 & 16.45 & 92.5 & 39.0 & 1.1\end{array}$

$\begin{array}{lrrrrr}39-6,83-85 & 421.54 & 8.65 & 66.0 & 51.6 & 1.3 \\ 39-6.104-106 & 421.75 & 45.71 & 216.6 & 80.0 & 1.2\end{array}$

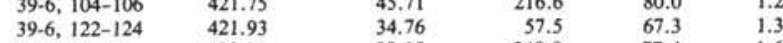

$\begin{array}{llllll}39-7,10-12 & 422.31 & 30.15 & 249.0 & 77.4 & 1.6 \\ 39-7,26-28 & 422.47 & 48.88 & 295.4 & 30.7 & 1.4\end{array}$

$\begin{array}{llllll}39-7,26-28 & 422.47 & 48.88 & 295.4 & 30.7 & 1.4 \\ 40-1,111-113 & 423.12 & 15.70 & 296.4 & 52.9 & 1.4\end{array}$

$\begin{array}{llllll}40-2,48-50 & 423.99 & 18.77 & 342.4 & 64.4 & 0.5\end{array}$

$\begin{array}{lrrrrr}41-1,29-31 & 432.30 & 13.92 & 240.5 & 44.6 & 1.1 \\ 41-2.145-147 & 434.96 & 7.56 & 165.4 & 48.7 & 1.2\end{array}$

$\begin{array}{llllll}41-3,12-14 & 435.13 & 31.10 & 216.4 & 44.1 & 0.7\end{array}$

$\begin{array}{llllll}41-3,24-26 & 435.25 & 19.43 & 93.7 & 48.5 & 0.5\end{array}$

$\begin{array}{lllrrr}41.4,70-72 & 437.21 & 14.08 & 169.2 & 45.2 & 0.6 \\ 41-5,59-61 & 438.60 & 18.30 & 51.9 & 49.0 & 1.3\end{array}$

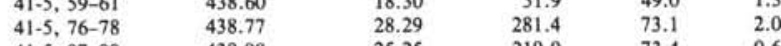

$\begin{array}{llllll}41-5,97-99 & 438.98 & 25.25 & 219.0 & 73.4 & 0.6 \\ 42-1,40-42 & 441.91 & 20.63 & 253.3 & 55.3 & 1.6\end{array}$

$\begin{array}{llllll}42-1,53-55 & 442.04 & 38.56 & 250.9 & 37.8 & 1.6\end{array}$

$\begin{array}{lrrrrr}42-2,81-83 & 443.82 & 32.79 & 185.1 & 36.3 & 0.6\end{array}$

$42-2,118-120 \quad 444.19$

$\begin{array}{llllll}42-4.5-7 & 446.06 & 33.91 & 242.1 & 54.4 & 0.9 \\ 42-4,62-64 & 446.63 & 46.65 & 291.4 & 59.9 & 2.0\end{array}$

$\begin{array}{rrrrrr}42-4,62-64 & 446.63 & 46.65 & 291.4 & 59.9 & 2.0 \\ 42-5,33-35 & 447.84 & 37.21 & 62.5 & 46.8 & 1.2\end{array}$

$\begin{array}{llllll}44-1,40-42 & 462.41 & 4.15 & 142.8 & 43.7 & 0.0 \\ 44-2,40-42 & 462.41 & 7.02 & 132.5 & 44.8 & 1.2\end{array}$

$\begin{array}{llllll}44-2,53-55 & 462.54 & 25.48 & 12.1 & 44.9 & 1.0\end{array}$

$\begin{array}{rrrrrr}50-1,41-43 & 518.22 & 8.13 & 190.5 & 35.1 & 2.4 \\ 50-2,54-56 & 519.85 & 49.71 & 315.4 & 37.8 & 1.4\end{array}$

$\begin{array}{lrrrrr}50-2,54-56 & 519.85 & 49.71 & 315.4 & 37.8 & 1.4 \\ 50-3,73-75 & 521.54 & 5.42 & 249.8 & 57.0 & 0.0\end{array}$

$\begin{array}{lrrrrr}50-3,73-75 & 521.54 & 5.42 & 249.8 & 57.0 & 0.0 \\ 50-7.15-17 & 526.96 & 16.29 & 175.4 & 56.7 & 1.2\end{array}$

$\begin{array}{llllll}51-1,58-60 & 527.99 & 9.11 & 74.3 & 54.0 & 1.4 \\ 51-1,58-60 & 527.99 & 9.18 & 80.0 & 56.6 & 1.3\end{array}$

$\begin{array}{llllll}52-1,94-96 & 537.95 & 163.88 & 33.8 & 35.3 & 0.9\end{array}$

$\begin{array}{llllll}52-1,101-103 & 538.02 & 29.33 & 35.0 & 39.9 & 1.6 \\ 52-3,4-6 & 540.05 & 88.43 & 75.4 & 37.5 & 1.1\end{array}$

$\begin{array}{llrlll}52-3,4-6 & 540.05 & 88.43 & 75.4 & 37.5 & 1.1 \\ 52-3,59-61 & 540.60 & 156.85 & 91.6 & 48.1 & 1.2 \\ 52-3.79-81 & 540.80 & 119.92 & 39.0 & 40.1 & 1.1\end{array}$

$\begin{array}{rrrrrr}52-3,79-81 & 540.80 & 119.92 & 39.0 & 40.1 & 1.1 \\ 54-2,58-60 & 558.39 & 35.14 & 271.6 & 56.4 & 1.3\end{array}$ 
Table 1. (Continued).

\begin{tabular}{|c|c|c|c|c|c|}
\hline $\begin{array}{c}\text { Core-Section } \\
\text { (interval in cm) }\end{array}$ & $\begin{array}{l}\text { Sub-bottom } \\
\text { depth }(m)\end{array}$ & $\begin{array}{c}\text { Intensity } \\
\left(\times 10^{-3} \mathrm{~A} / \mathrm{m}\right)\end{array}$ & $\begin{array}{c}\text { Relative } \\
\text { decl. } \\
\text { (degrees) }\end{array}$ & $\begin{array}{c}\text { Incl. } \\
\text { (degrees) }\end{array}$ & $\begin{array}{c}\text { Error } \\
\text { in incl. } \\
\text { (degrees) }\end{array}$ \\
\hline \multicolumn{6}{|l|}{ Hole 582B (Cont.) } \\
\hline $55-1,121-123$ & 567.22 & 71.11 & 279.0 & 39.9 & 1.1 \\
\hline $55-2,19-21$ & 567.70 & 69.65 & 226.7 & 39.2 & 1.1 \\
\hline $55-4,106-108$ & 571.57 & 138.01 & 90.7 & 33.6 & 1.7 \\
\hline $57-1,76-78$ & 586.07 & 37.67 & 348.3 & 52.5 & 1.5 \\
\hline $57-2,6-8$ & 586.87 & 35.87 & 61.2 & 59.9 & 1.1 \\
\hline $57-3,42-44$ & 588.73 & 39.99 & 265.2 & 51.2 & 0.4 \\
\hline $57-4,45-47$ & 590.26 & 21.20 & 245.9 & 54.8 & 1.4 \\
\hline $57-5,40-42$ & 590.71 & 111.61 & 327.4 & 55.0 & 2.6 \\
\hline $58-1,37-39$ & 595.28 & 82.12 & 225.0 & 49.3 & 2.0 \\
\hline $58-2,60-62$ & 597.01 & 80.95 & 346.1 & 61.1 & 1.2 \\
\hline $58-3,137-139$ & 599.28 & 60.90 & 341.0 & 63.7 & 1.4 \\
\hline $58-4,32-34$ & 599.73 & 36.32 & 25.0 & 47.5 & 1.4 \\
\hline $58-5,31-33$ & 601.22 & 51.80 & 345.8 & 55.7 & 1.0 \\
\hline $58-5,112-114$ & 602.03 & 30.66 & 80.3 & 35.3 & 1.0 \\
\hline $59-1,70-72$ & 605.21 & 26.50 & 208.6 & 63.5 & 1.4 \\
\hline $59-2,74-76$ & 606.75 & 86.38 & 78.6 & 53.1 & 1.3 \\
\hline $59-3,88-90$ & 608.39 & 21.59 & 99.8 & -51.6 & 1.8 \\
\hline $60-1,110-112$ & 615.21 & 24.47 & 274.8 & 54.7 & 1.3 \\
\hline $60-2,44-46$ & 616.05 & 28.55 & 122.0 & 55.2 & 1.9 \\
\hline $61-1,62-64$ & 624.33 & 2.23 & 313.1 & -41.8 & 3.1 \\
\hline $61-2,92-94$ & 626.13 & 22.14 & 237.7 & -57.9 & 2.2 \\
\hline $61-4,41-43$ & 628.62 & 46.98 & 1.8 & -44.7 & 1.9 \\
\hline $62-1,79-81$ & 634.10 & 13.59 & 324.7 & -58.9 & 2.9 \\
\hline $62-2,72-74$ & 635.53 & 1.35 & 31.4 & -39.6 & 3.3 \\
\hline $62-3,79-81$ & 637.10 & 43.50 & 175.9 & -44.0 & 0.8 \\
\hline $62-4,55-57$ & 638.36 & 34.54 & 145.3 & 43.9 & 2.1 \\
\hline $63-1,61-63$ & 643.52 & 0.60 & 339.3 & -27.7 & 11.0 \\
\hline $63 \cdot 2,58-60$ & 644.99 & 16.52 & 40.8 & -42.7 & 2.2 \\
\hline $63-3,30-32$ & 646.21 & 11.84 & 323.9 & -52.6 & 1.4 \\
\hline $64-1,67-69$ & 653.18 & 4.68 & 340.2 & -34.6 & 3.0 \\
\hline $64-2,74-76$ & 654.75 & 7.16 & 350.8 & -60.1 & 1.6 \\
\hline $64-3,77-79$ & 656.28 & 3.72 & 165.0 & -48.9 & 1.1 \\
\hline $64-4,73-75$ & 657.74 & 0.83 & 235.8 & -10.5 & 5.4 \\
\hline $64-5,83-85$ & 659.34 & 0.22 & 191.9 & -44.4 & 17.6 \\
\hline $64-6,126-128$ & 661,27 & 4.37 & 27.0 & -51.6 & 1.4 \\
\hline $65-1,15-17$ & 662.26 & 14.68 & 6.3 & 57.4 & 0.7 \\
\hline $66-2,28-30$ & 673.59 & 17.43 & 1.6 & 47.9 & 1.2 \\
\hline $66-3,63-65$ & 675.44 & 18.11 & 52.7 & 54.5 & 1.7 \\
\hline $67-2,103-105$ & 684.04 & 3.41 & 65.0 & 47.8 & 2.9 \\
\hline $68-2,12-14$ & 692,83 & 1.17 & 23.2 & 48.7 & 5.5 \\
\hline $68-2,60-62$ & 693.31 & 0.42 & 302.2 & -39.8 & 18.6 \\
\hline $70-2,59-61$ & 712.70 & 1.45 & 253.7 & -38.0 & 2.7 \\
\hline $71-1,83-85$ & 721.14 & 0.36 & 84.2 & 40.3 & 10.0 \\
\hline $72-1,13-15$ & 730.14 & 0.47 & 20.7 & -12.5 & 2.6 \\
\hline $73-1,103-105$ & 740.74 & 0.50 & 64.9 & -27.9 & 2.5 \\
\hline $73-2,17-19$ & 741.38 & 1.01 & 306.6 & -43.0 & 9.7 \\
\hline
\end{tabular}

Note: decl. = declination; incl. $=$ inclination

ceptionally high; this normal-polarity interval may include another, older normal event, such as the Cobb Mountain Event (Mankinen et al., 1978).

Four stages in the depositional history, including a drastic change, are defined on the basis of the calculated accumulation rates: (IV) a late Pliocene to Jaramillo Event $-100 \mathrm{~m} / \mathrm{Ma}$; (III) the Jaramillo Event to $0.65 \mathrm{Ma}-300$ to $600 \mathrm{~m} / \mathrm{Ma}$; (II) 0.65 to $0.52 \mathrm{Ma}$ (an interval characterized by interbedded turbidites) -3530 $\mathrm{m} / \mathrm{Ma}$; and (I) $0.52 \mathrm{Ma}$ to present $-200 \mathrm{~m} / \mathrm{Ma}$ (Fig. 5). The main part of the sediment now in the Nankai Trough was deposited in a limited time interval by turbidites from the northeast (Taira and Niitsuma, this volume). Deposition should be related not only to the present location of the site in Nankai Trough, but also to the changes in the relative position of the site with plate motion. The change in sedimentation can be estimated to have occurred when the site crossed over the outer swell. The model of Minster and Jordan (1979) describes the relative motion of the Philippine Sea Plate as $1.2^{\circ} / \mathrm{Ma}$ with the pole at $48.3^{\circ} \mathrm{N}$ and $162.5^{\circ} \mathrm{E}$. Site 582 therefore would move toward the northeast at a rate of $61 \mathrm{~km} /$

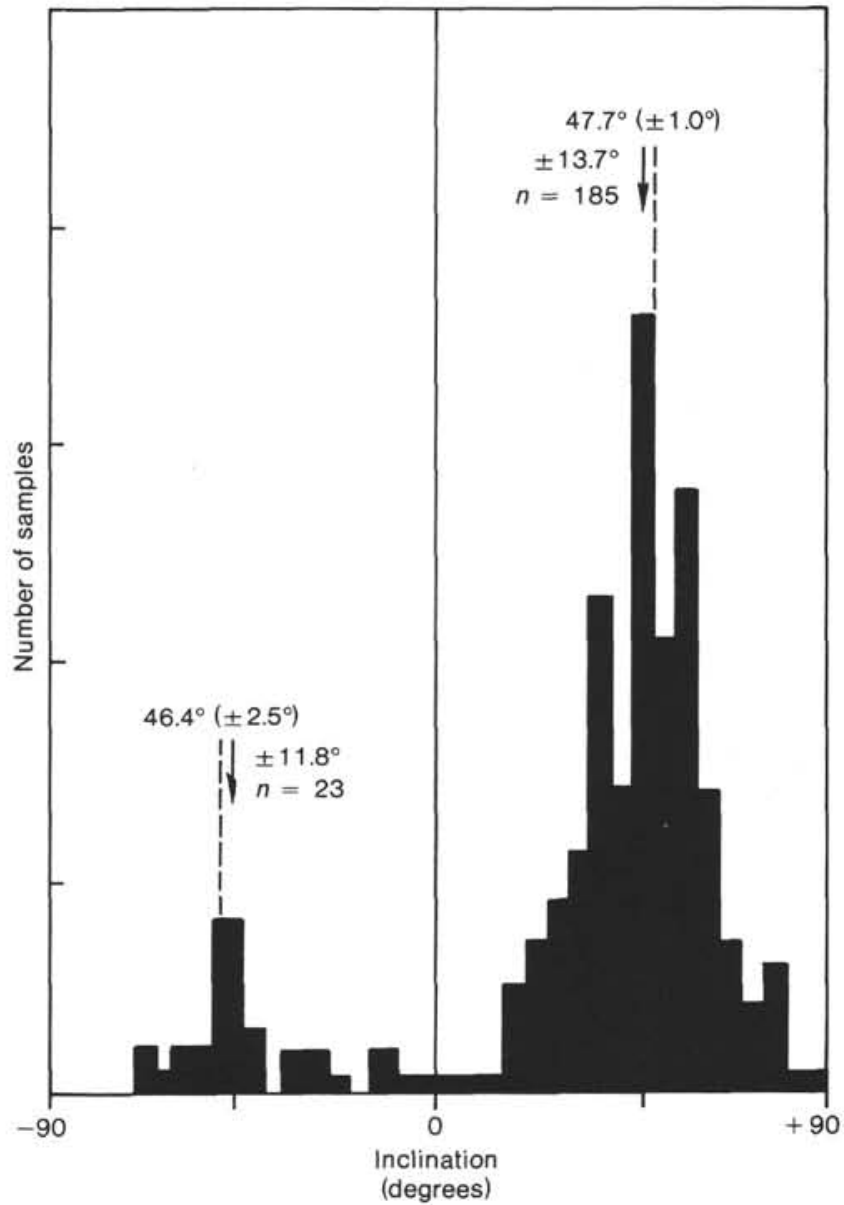

Figure 4. Frequency distribution and statistics (mean, standard error of the mean, and standard deviation) for the measured inclinations in samples from Site 582. Dotted lines correspond to the inclinations of the geocentric axial dipole field.

$\mathrm{Ma}$, and its trajectory for the last $2 \mathrm{Ma}$ shows that it crossed over the outer swell axis at $1.15 \mathrm{Ma}$ (Fig. 6). Site 297 , still located on the south side of the outer swell axis, has an accumulation rate of $140 \mathrm{~m} / \mathrm{Ma}$. The boundary between lithologic Units 2 and 3 at Site 297 is located at $90 \mathrm{~m}$ sub-bottom, at the boundary between diatom biostratigraphic Zones NPD17 and NPD16 (0.65 Ma; Niitsuma and Akiba, this volume; Karig, Ingle, et al., 1975). This rate is higher than the $50-100 \mathrm{~m} / \mathrm{Ma}$ of Site 582 at $1.15 \mathrm{Ma}$, when that site was located on the swell. The contrast in accumulation rates indicates that the supply of sediment was less then than now and that for the last $0.52 \mathrm{Ma}$ the rate at Site 297 has been comparable to that at Site 582. The accumulation rate is controlled not only by the relative position of the site with respect to the trough axis, but also by the supply of sediments, which is influenced by the tectonic framework in the hinterland. The sediment supply at Site 582 increased remarkably at $0.92 \mathrm{Ma}$, the end of the Jaramillo Event, after that site crossed the outer swell. This change can be estimated from the increase in accumulation rate and intensity of remanent magnetization (Fig. 3) and from the existence of turbidites above this horizon (boundary of Units 1 and 2), recorded by the seismic profiler as Re- 


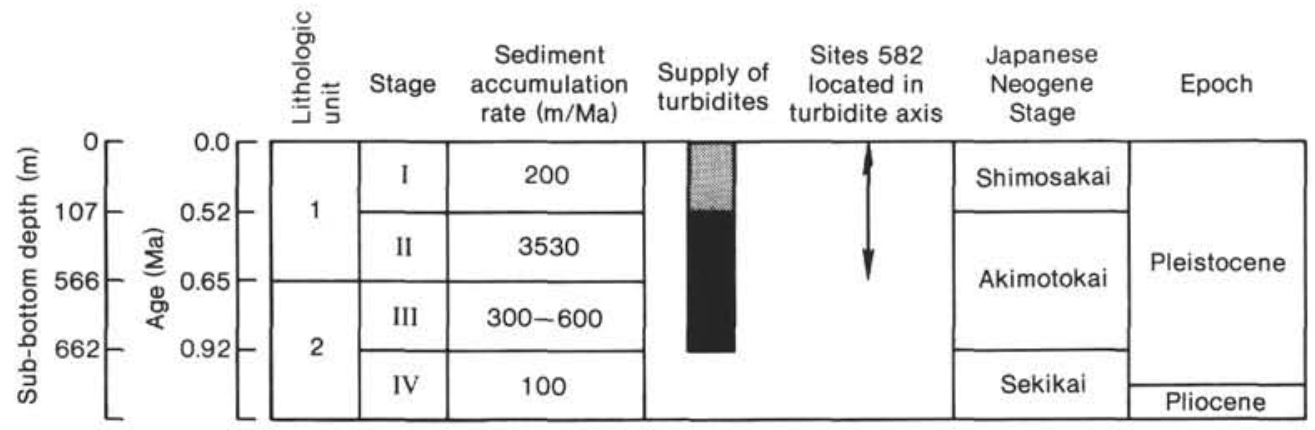

Figure 5. Stage division by accumulation rate at Site 582 .

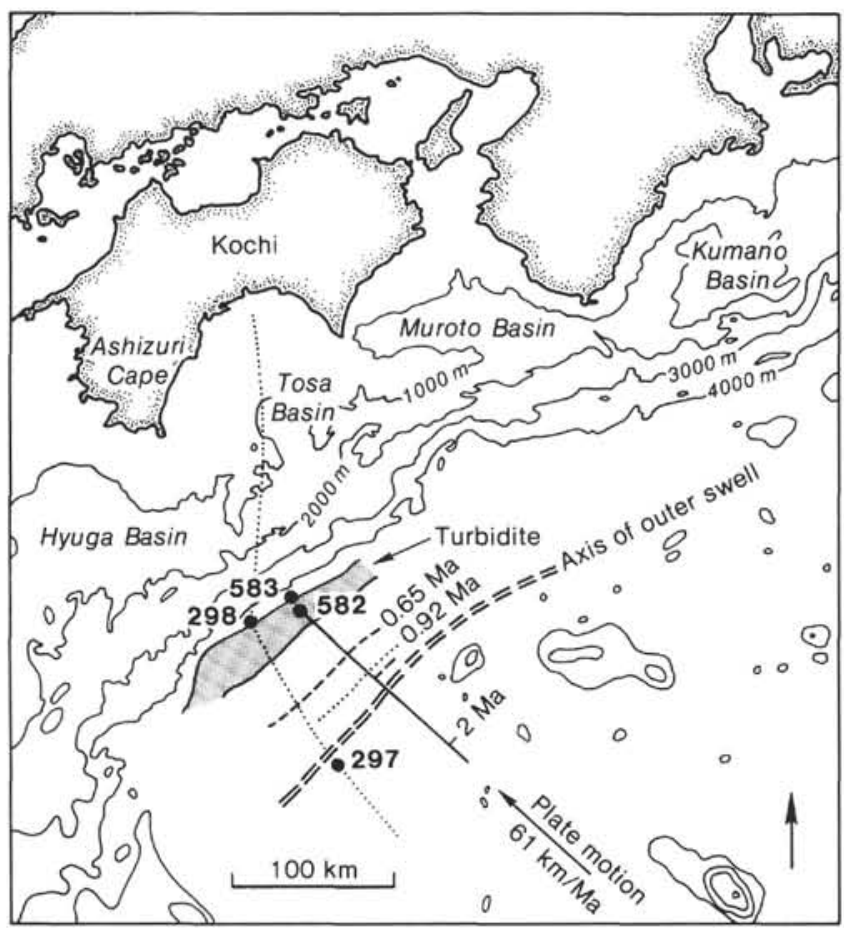

Figure 6. Plate motion and DSDP sites in the Nankai Trough. Stippled pattern corresponds to the Trough-fill turbidites. Dotted line represents line of seismic profile shown in Figure 7. Solid line shows the trajectory of Site 582 .

flector $\mathrm{E}$ along the trough (Fig. 7). Site 582 entered the axial turbidite zone at $0.65 \mathrm{Ma}$ (Stage III/II), and at $0.52 \mathrm{Ma}$ (Stage II/I) the supply of the turbidites decreased, even though the site was still in the axial zone (Fig. 6). During Stage I (Fig. 5), the thick turbidite pile moved northwest, and is now in a zone $15-20 \mathrm{~km}$ wide along the Nankai Trough (Figs. 6, 7). If we move the position of Site 582 back at the rate of plate motion for the last $0.65 \mathrm{Ma}$, the site reaches the location of the present 4600-m depth contour, where it should have entered into the turbidite axis (Stage III/II). Evidently, large amounts of sediment were supplied to the Nankai Trough as turbidites during a limited time interval from 0.92 to $0.52 \mathrm{Ma}$, and the southern boundary of the turbidite axial zone was located near the present 4600 -m depth contour. The inner part of the sediment pile moved northwest and is now incorporated into the accretionary prism on the inner slope of the Nankai Trough.
Some events in the tectonic evolution of the Japanese island arc correspond to those of the sediment supply to the Nankai Trough. Regional unconformities occur widely in the Kanto (Niitsuma and Akiba, in press; this volume) and Kinki areas (Nakeseko, 1984) around 0.5 Ma, just below the extinction level of Pseudoemiliania lacunosa. The Japanese Neogene stages above and below this unconformity are the Shimosakai and Akimotokai, respectively (Fig. 5). An unconformity can mark a tectonic change, in this case perhaps the collision of the Izu Peninsula with the Honshu Arc and the development of a large-scale strike-slip fault in central Japan (Niitsuma and Akiba, in press; this volume).

The Stage III/IV boundary corresponds to the boundary between the Akimotokai and Sekikai stages in the Kanto area (Figs. 1, 5), which in turn corresponds to the time of initiation of the collision between the Izu Peninsula and the Honshu Arc and the uplift of the Akaishi Mountains in central Japan. In Sekikai, huge amounts of gravel were supplied and a conglomeratic delta was constructed (Ogasa Group) on the deep-sea terrace, which had been filled with turbidites (Kakegawa Group) in the Shizuoka area, south of the Akaishi Mountains. The lower boundary of the conglomerate is dated by magnetostratigraphy at the Jaramillo Event (Nakagawa et al., 1982). The collision of the Izu Arc with the Honshu Arc caused large-scale mountain building in central Japan at the Stage IV/III boundary.

\section{Site 583}

At Site 583, eight holes were drilled and 304 paleomagnetic samples were collected and studied (Figs. 8, 9, 10; Table 2). The intensity was not affected by AF demagnetization, and the MDF was higher than $20 \mathrm{mT}$ (Fig. 2).

The distribution of measured intensities of remanent magnetization after $15-\mathrm{mT}$ AF demagnetization has a pattern similar to those from Stages I and II of Site 582 (Fig. 11), but the intensities measured in the tops of these eight holes are weaker.

Sediments are subhorizontal in Holes 583, 583A, 583E, $583 \mathrm{~F}$, and $583 \mathrm{G}$, and have positive magnetic inclinations, except at several horizons. Considering the intensity distribution and paleontologic data, all Site 583 sediments are correlative with the upper sediments at Site 582. In the inclination diagrams (Fig. 12), the distribution of positive inclination is unimodal, and the mean values 


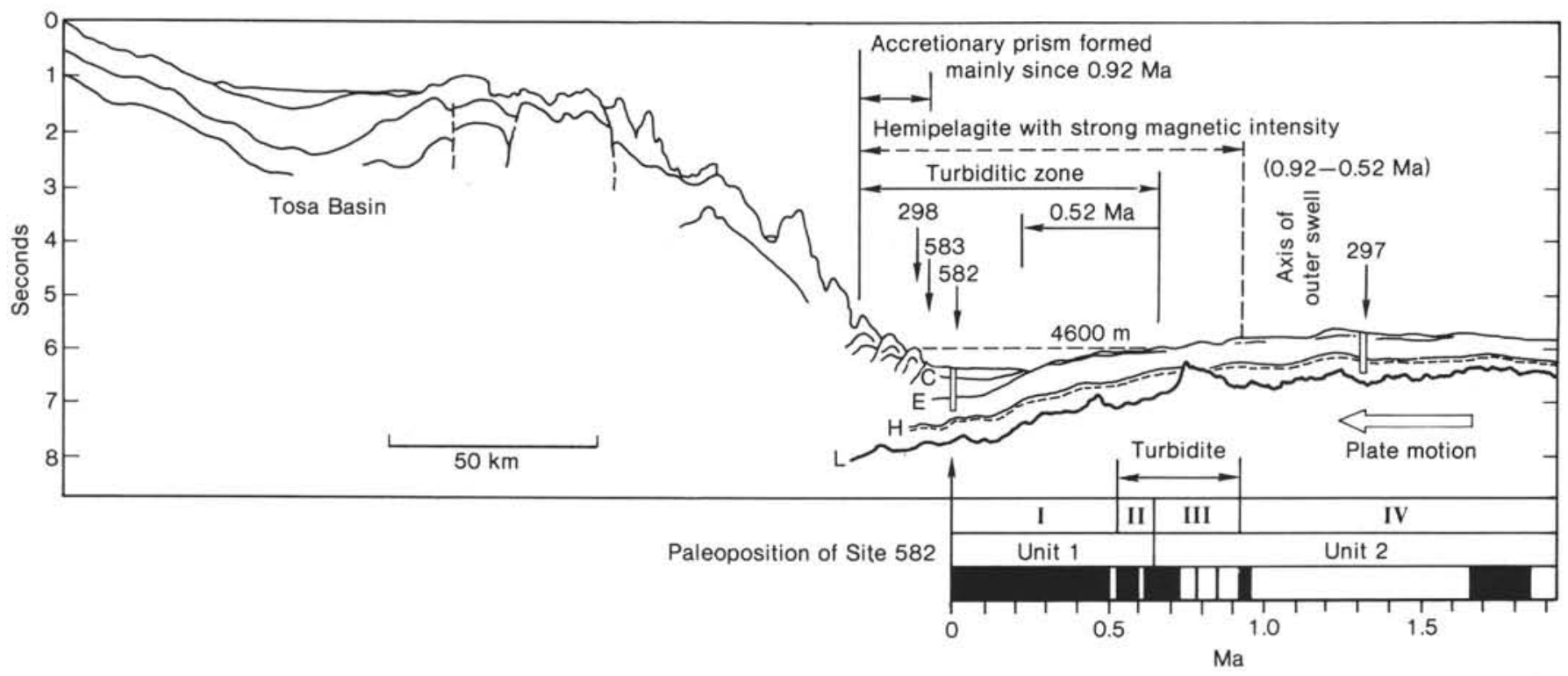

Figure 7. Schematic cross section of the Nankai Trough and the plate-motion trajectory of Site 582 . Ratio of vertical to horizontal scale is about 16:1. This cross section is located in Figure 6.
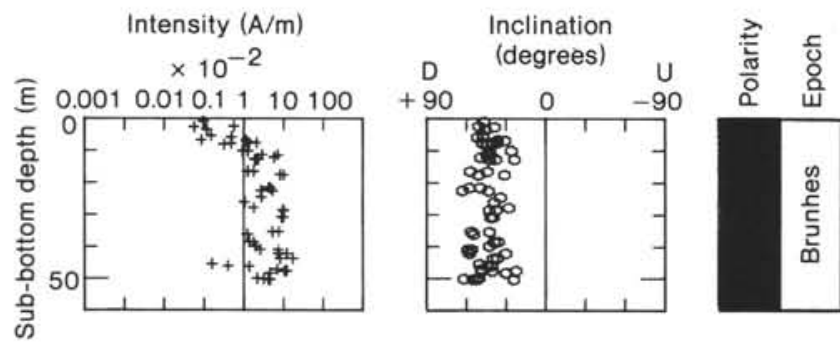

Figure 8. Magnetostratigraphy of Hole 583A. Measurements by a ringcore-type fluxgate spinner magnetometer after $15-\mathrm{mT}$ AF demagnetization.
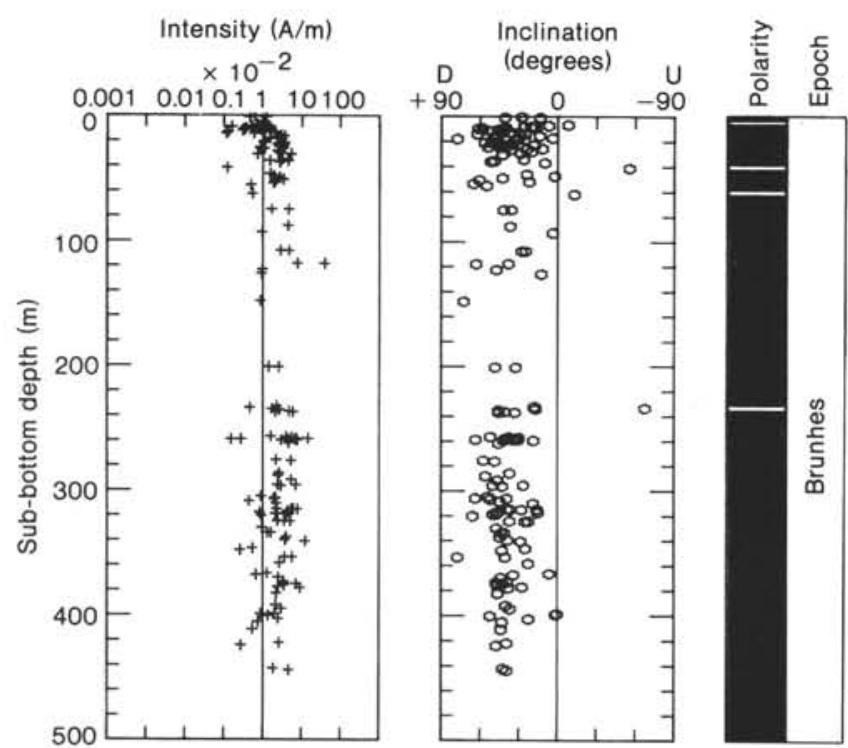

Figure 9. Magnetostratigraphy of Holes 583, 583F, and 583G. Measurements by a ring-core-type fluxgate spinner magnetometer after 15-mT AF demagnetization.

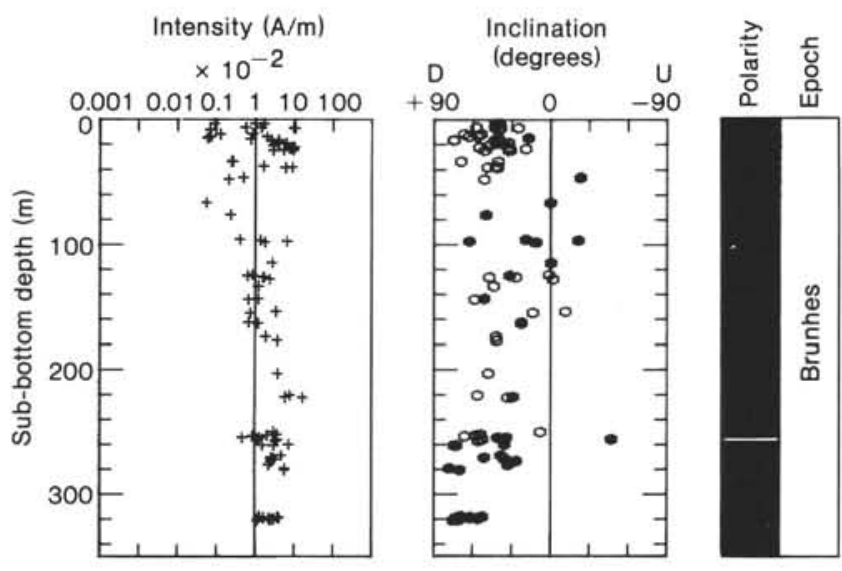

Figure 10. Magnetostratigraphy of Holes 583B, 583C, and 583D. Measurements by a ring-core-type fluxgate spinner magnetometer after $15-\mathrm{mT}$ AF demagnetization. Open circles $=$ after bedding correction; closed circles $=$ before bedding correction.

are significantly shallower than those of Site 582, where they are almost parallel to the geocentric axial dipole field. Because of the positive correlation between the amount of deviation of the inclinations (Fig. 12) and tectonic disturbance of the sediments, the shallowing of the inclinations can be regarded as a result of the changes in physical properties and of the rotation of magnetic minerals during accretionary processes. This estimate is also supported by the anisotropy of susceptibility that bends along an axis parallel to the Nankai Trough (Taira and Niitsuma, this volume).

The extinction level of Pseudoemiliania lacunosa is at $88 \mathrm{~m}$ sub-bottom in Hole 583 (Lang, this volume), almost the same depth as at Site 582. Accumulation rates above this horizon are therefore the same at both sites, despite the location of Site 583 on the inner slope and of 
Table 2. Paleomagnetic measurements after 15-mT AF demagnetization at Site 583.

\begin{tabular}{|c|c|c|c|c|c|c|c|}
\hline & & & & & & & Bedding dip \\
\hline $\begin{array}{l}\text { Core-Section } \\
\text { (interval in } \mathrm{cm} \text { ) }\end{array}$ & $\begin{array}{l}\text { Sub-bottom } \\
\text { depth }(m)\end{array}$ & $\begin{array}{c}\text { Intensity } \\
\left(\times 10^{-3} \mathrm{~A} / \mathrm{m}\right)\end{array}$ & $\begin{array}{c}\text { Relative } \\
\text { decl. } \\
\text { (degrees) }\end{array}$ & $\begin{array}{c}\text { Incl. } \\
\text { (degrees) }\end{array}$ & $\begin{array}{c}\text { Error } \\
\text { in incl. } \\
\text { (degrees) }\end{array}$ & $\begin{array}{l}\text { Relative } \\
\text { Decl. Incl. } \\
\text { (tilt corr.) }\end{array}$ & $\begin{array}{l}\text { Azimuth } \\
\text { (tilt corr.) Dip } \\
\text { (degrees) }\end{array}$ \\
\hline
\end{tabular}

Hole 583

\begin{tabular}{|c|c|c|c|c|}
\hline $1-1,43-45$ & 0.44 & 6.14 & 70.7 & 27.9 \\
\hline $1-1,107-109$ & 1.08 & 4.68 & 61.6 & 40.9 \\
\hline $1-1,111-113$ & 1.12 & 12.20 & 52.7 & 13.7 \\
\hline $2-1,134-136$ & 6.85 & 9.71 & 283.8 & -8.2 \\
\hline $2-2,45-47$ & 7.46 & 7.16 & 217.5 & 6.9 \\
\hline $2-2,132-134$ & 8.33 & 8.11 & 199.0 & 18.1 \\
\hline $2-2,132-134$ & 8.33 & 7.32 & 227.2 & 20.8 \\
\hline $2-2,137-139$ & 8.38 & 14.77 & 215.7 & 25.8 \\
\hline $2-2,144-146$ & 8.45 & 5.10 & 227.5 & 18.6 \\
\hline $2-3,37-39$ & 8.88 & 1.59 & 221.7 & 40.7 \\
\hline $2-3,42-44$ & 8.93 & 11.60 & 230.7 & 17.4 \\
\hline $2-3,133-135$ & 9.84 & 3.61 & 183.6 & 58.2 \\
\hline $2-3,139-141$ & 9.90 & 10.03 & 231.0 & 61.7 \\
\hline $2-4,14-16$ & 10.15 & 11.00 & 254.1 & 44.8 \\
\hline $2-4,22-24$ & 10.23 & 7.86 & 212.2 & 40.5 \\
\hline $2-4,96-98$ & 10.97 & 16.12 & 204.7 & 45.9 \\
\hline $2-4,101-103$ & 11.02 & 8.51 & 202.7 & 46.4 \\
\hline $2-4,104-106$ & 11.05 & 3.32 & 235.7 & 42.5 \\
\hline $2-5,25-27$ & 11.76 & 3.05 & 191.5 & 52.3 \\
\hline $2-5,130-132$ & 12.81 & 1.28 & 226.0 & 43.1 \\
\hline $2-6,11-13$ & 13.12 & 20.46 & 212.1 & 29.9 \\
\hline $2-6,25-27$ & 13.26 & 10.77 & 201.6 & 35.9 \\
\hline $2-6,115-117$ & 14.16 & 5.89 & 194.1 & 25.2 \\
\hline $2-6,119-121$ & 14.20 & 1.16 & 216.5 & 62.4 \\
\hline $3-1,60-62$ & 15.61 & 29.19 & 29.5 & 14.0 \\
\hline $3-1,120-122$ & 16.21 & 35.88 & 53.8 & 49.3 \\
\hline $3-2,80-82$ & 17.31 & 25.19 & 5.6 & 3.9 \\
\hline $3-2,110-112$ & 17.61 & 23.71 & 5.6 & 31.6 \\
\hline $3-2,140-142$ & 17.91 & 23.64 & 358.2 & 30.8 \\
\hline $3-3,18-20$ & 18.19 & 15.02 & 49.7 & 77.8 \\
\hline $3-3,53-55$ & 18.54 & 29.97 & 6.9 & 25.7 \\
\hline $3-4,115-117$ & 20.66 & 10.48 & 347.7 & 46.9 \\
\hline $3-4,140-142$ & 20.91 & 10.68 & 338.9 & 51.2 \\
\hline $3-5,30-32$ & 21.31 & 11.10 & 335.9 & 56.7 \\
\hline $3-5,66-68$ & 21.67 & 36.13 & 344.9 & 36.2 \\
\hline $3-5,100-102$ & 22.01 & 36.05 & 353.7 & 36.0 \\
\hline $3-5,130-132$ & 22.31 & 24.86 & 349.3 & 35.0 \\
\hline $3-6,10-12$ & 22.61 & 32.95 & 26.9 & 43.5 \\
\hline $3-6,58-60$ & 23.09 & 26.98 & 54.6 & 18.2 \\
\hline $4-1,80-82$ & 23.81 & 25.57 & 61.8 & 45.4 \\
\hline $4-1,110-112$ & 24.11 & 25.77 & 70.3 & 39.2 \\
\hline $4-1,144-146$ & 24.45 & 26.24 & 62.3 & 43.9 \\
\hline $4-2,18-20$ & 24.69 & 34.03 & 332.1 & 54.0 \\
\hline $4-2,122-124$ & 25.73 & 8.54 & 326.8 & 11.9 \\
\hline $4-3,18-20$ & 26.19 & 10.94 & 75.1 & 24.2 \\
\hline $4-3,53-55$ & 26.54 & 31.69 & 95.1 & 36.3 \\
\hline $4-4,60-62$ & 28.11 & 24.22 & 235.9 & 20.2 \\
\hline $4-5,60-62$ & 29.61 & 27.95 & 211.7 & 28.7 \\
\hline $4-6,14-16$ & 30.65 & 54.15 & 167.9 & 42.8 \\
\hline $4-6,17-19$ & 30.68 & 7.27 & 185.6 & 43.1 \\
\hline $5-2,52-54$ & 34.53 & 31.59 & 178.4 & 26.3 \\
\hline $5-3,41-43$ & 35.92 & 15.18 & 16.0 & 49.3 \\
\hline $5-3,51-53$ & 36.02 & 45.24 & 11.1 & 51.9 \\
\hline $5-4,21-23$ & 37.22 & 27.40 & 169.1 & 10.0 \\
\hline $5-6,145-147$ & 41.46 & 1.22 & 171.5 & -55.3 \\
\hline $7-1,50-52$ & 46.41 & 15.58 & 54.3 & 24.0 \\
\hline $7-2,50-52$ & 47.91 & 19.28 & 93.1 & 2.5 \\
\hline $7-3,50-52$ & 49.41 & 26.83 & 107.7 & 42.8 \\
\hline $7-4,50-52$ & 50.91 & 33.58 & 65.2 & 60.7 \\
\hline $7-5,50-52$ & 52.41 & 20.74 & 88.9 & 22.0 \\
\hline $7-6,50-52$ & 53.91 & 18.63 & 84.9 & 65.2 \\
\hline $8-1,5-7$ & 55.46 & 4.92 & 102.5 & 55.0 \\
\hline $8, C C(3-5)$ & 62.34 & 5.50 & 7.5 & -12.8 \\
\hline $11-1,134-136$ & 74.85 & 16.90 & 286.4 & 35.9 \\
\hline $11-1,138-140$ & 74.89 & 47.20 & 309.1 & 41.9 \\
\hline $13-1,100-102$ & 88.01 & 45.45 & 74.1 & 36.7 \\
\hline $14-1,115-117$ & 93.16 & 9.54 & 253.3 & 3.8 \\
\hline $17-1,79-81$ & 107.80 & 29.18 & 31.2 & 24.7 \\
\hline $17-1,85-87$ & 107.86 & 48.09 & 32.4 & 28.0 \\
\hline $19-1,107-109$ & 118.08 & 79.29 & 100.0 & 38.0 \\
\hline $19-1,113-115$ & 118.14 & 400.70 & 81.7 & 63.0 \\
\hline $20-1,79-81$ & 122.80 & 9.87 & 260.1 & 47.3 \\
\hline
\end{tabular}


Table 2. (Continued).

\begin{tabular}{|c|c|c|c|c|c|c|c|c|c|c|}
\hline \multirow[b]{2}{*}{$\begin{array}{c}\text { Core-Section } \\
\text { (interval in cm) }\end{array}$} & \multirow[b]{2}{*}{$\begin{array}{l}\text { Sub-bottom } \\
\text { depth (m) }\end{array}$} & \multirow[b]{2}{*}{$\begin{array}{c}\text { Intensity } \\
\left(\times 10^{-3} \mathrm{~A} / \mathrm{m}\right)\end{array}$} & \multirow[b]{2}{*}{$\begin{array}{c}\text { Relative } \\
\text { decl. } \\
\text { (degrees) }\end{array}$} & \multirow[b]{2}{*}{$\begin{array}{c}\text { Incl. } \\
\text { (degrees) }\end{array}$} & \multirow[b]{2}{*}{$\begin{array}{c}\text { Error } \\
\text { in incl. } \\
\text { (degrees) }\end{array}$} & \multirow[b]{2}{*}{$\begin{array}{l}\text { Relative } \\
\text { Decl. } \\
\text { (tilt corr. }\end{array}$} & \multirow[b]{2}{*}{$\begin{array}{l}\text { Incl. } \\
\text { r.) }\end{array}$} & & Bedding di & \\
\hline & & & & & & & & & $\begin{array}{l}\text { Azimuth } \\
\text { (tilt corr.) } \\
\text { (degrees) }\end{array}$ & Dip \\
\hline Hole 583 (Cont.) & & & & & & & & & & \\
\hline $21-1,15-17$ & 126.16 & 9.39 & 99.9 & 12.6 & 1.6 & & & & & \\
\hline $26-1,20-22$ & 148.21 & 8.78 & 308.9 & 72.5 & 1.7 & & & & & \\
\hline Hole $583 \mathrm{~A}$ & & & & & & & & & & \\
\hline $1-1,95-97$ & 0.96 & 0.96 & 290.9 & 46.8 & 7.0 & & & & & \\
\hline $1-2,92-94$ & 2.43 & 5.66 & 318.3 & 50.7 & 1.4 & & & & & \\
\hline $1-2,121-123$ & 2.72 & 0.56 & 292.6 & 38.8 & 9.6 & & & & & \\
\hline $1-3,50-52$ & 3.51 & 1.18 & 350.0 & 45.5 & 9.9 & & & & & \\
\hline $2-1,135-137$ & 5.36 & 1.51 & 248.3 & 47.4 & 4.7 & & & & & \\
\hline $2-2,41-43$ & 5.92 & 4.87 & 167.7 & 51.7 & 1.0 & & & & & \\
\hline $2-2,130-132$ & 6.81 & 0.86 & 187.7 & 36.4 & 3.8 & & & & & \\
\hline $2-2,143-145$ & 6.94 & 11.40 & 171.0 & 31.0 & 0.8 & & & & & \\
\hline $2-3,63-65$ & 7.64 & 20.70 & 202.8 & 36.5 & 1.1 & & & & & \\
\hline $2-3,69-71$ & 7.70 & 13.39 & 179.3 & 48.0 & 0.6 & & & & & \\
\hline $2-3,81-83$ & 7.82 & 4.81 & 171.2 & 40.8 & 1.1 & & & & & \\
\hline $2-3,118-120$ & 8.19 & 3.18 & 183.6 & 44.1 & 2.7 & & & & & \\
\hline $3-1,105-107$ & 10.06 & 9.39 & 199.6 & 42.5 & 1.6 & & & & & \\
\hline $3-1,111-113$ & 10.12 & 12.63 & 196.6 & 26.1 & 1.5 & & & & & \\
\hline $3-2,88-90$ & 11.39 & 28.59 & 69.4 & 42.3 & 1.6 & & & & & \\
\hline $3-2,93-95$ & 11.44 & 71.73 & 71.4 & 44.8 & 1.8 & & & & & \\
\hline $3-3,15-17$ & 12.16 & 57.19 & 80.5 & 49.2 & 1.2 & & & & & \\
\hline $3-3,78-80$ & 12.79 & 21.71 & 82.8 & 23.7 & 1.5 & & & & & \\
\hline $3-3,80-82$ & 12.81 & 22.88 & 77.1 & 37.7 & 1.3 & & & & & \\
\hline $3-3,82-84$ & 12.83 & 18.92 & 85.4 & 42.4 & 0.8 & & & & & \\
\hline $4-2,101-103$ & 16.52 & 12.58 & 141.3 & 57.2 & 0.9 & & & & & \\
\hline $4-2,105-107$ & 16.56 & 17.56 & 166.0 & 44.0 & 1.1 & & & & & \\
\hline $4-3,60-62$ & 17.61 & 82.47 & 121.4 & 31.2 & 1.0 & & & & & \\
\hline $4-3,63-65$ & 17.64 & 101.36 & 115.9 & 50.8 & 1.1 & & & & & \\
\hline $5-2,109-111$ & 21.60 & 41.40 & 93.8 & 57.7 & 1.5 & & & & & \\
\hline $5-2,116-118$ & 21.67 & 46.52 & 80.4 & 49.5 & 1.4 & & & & & \\
\hline $5-3,51-53$ & 22.52 & 26.71 & 75.9 & 62.9 & 1.6 & & & & & \\
\hline $5-3,61-63$ & 22.62 & 52.68 & 89.4 & 43.2 & 1.1 & & & & & \\
\hline $6-1,63-65$ & 24.64 & 27.42 & 207.0 & 34.0 & 1.2 & & & & & \\
\hline $6-2,70-72$ & 26.21 & 10.44 & 201.6 & 39.1 & 1.2 & & & & & \\
\hline $6-3,92-94$ & 27.93 & 17.70 & 207.1 & 27.9 & 1.5 & & & & & \\
\hline $6-4,10-12$ & 28.61 & 94.56 & 213.7 & 37.5 & 1.5 & & & & & \\
\hline $6-4,18-20$ & 28.69 & 101.50 & 215.2 & 42.8 & 1.4 & & & & & \\
\hline $7-2,29-31$ & 30.80 & 87.93 & 306.1 & 41.6 & 1.3 & & & & & \\
\hline $7-2,38-40$ & 30.89 & 99.73 & 36.3 & 39.5 & 1.9 & & & & & \\
\hline $8-1,136-138$ & 35.37 & 75.75 & 280.7 & 56.4 & 2.0 & & & & & \\
\hline $8-1,144-146$ & 35.45 & 52.56 & 301.2 & 42.6 & 1.5 & & & & & \\
\hline $8-2,69-71$ & 36.20 & 12.26 & 303.5 & 54.5 & 1.4 & & & & & \\
\hline $8-4,3-5$ & 38.54 & 13.56 & 319.7 & 35.7 & 0.8 & & & & & \\
\hline $8-4,12-14$ & 38.63 & 17.53 & 310.2 & 38.9 & 0.8 & & & & & \\
\hline $9-1,92-94$ & 39.93 & 19.81 & 136.8 & 42.7 & 0.6 & & & & & \\
\hline $9-2,46-48$ & 40.97 & 25.98 & 105.4 & 56.0 & 1.4 & & & & & \\
\hline $9-2,51-53$ & 41.02 & 74.74 & 107.5 & 59.1 & 1.2 & & & & & \\
\hline $9-3,19-21$ & 42.20 & 73.38 & 122.2 & 30.1 & 0.6 & & & & & \\
\hline $9-3,19-21$ & 42.20 & 119.81 & 135.3 & 57.6 & 1.3 & & & & & \\
\hline $9-4,20-22$ & 43.71 & 173.45 & 124.3 & 36.6 & 0.8 & & & & & \\
\hline $9-4,26-28$ & 43.77 & 83.09 & 126.7 & 39.7 & 1.1 & & & & & \\
\hline $10-1,145-147$ & 45.46 & 1.57 & 322.3 & 50.1 & 5.1 & & & & & \\
\hline $10-2,55-57$ & 46.06 & 4.03 & 279.8 & 40.6 & 1.7 & & & & & \\
\hline $10-2,71-73$ & 46.22 & 13.64 & 280.7 & 43.9 & 1.3 & & & & & \\
\hline $10-3,14-16$ & 47.15 & 70.01 & 270.4 & 48.7 & 2.1 & & & & & \\
\hline $10-3,64-66$ & 47.65 & 121.34 & 256.2 & 22.4 & 2.2 & & & & & \\
\hline $10-3,75-77$ & 47.76 & 105.95 & 278.3 & 40.5 & 1.9 & & & & & \\
\hline $10-3,133-135$ & 48.34 & 45.39 & 289.8 & 30.1 & 1.2 & & & & & \\
\hline $11-1,94-96$ & 49.95 & 21.69 & 5.7 & 50.4 & 0.6 & & & & & \\
\hline $11-1,118-120$ & 50.19 & 31.59 & 30.3 & 61.8 & 1.1 & & & & & \\
\hline $11-1,137-139$ & 50.38 & 41.85 & 348.2 & 54.9 & 0.6 & & & & & \\
\hline $11-1,139-141$ & 50.40 & 45.88 & 334.6 & 51.8 & 1.1 & & & & & \\
\hline $11-1,146-148$ & 50.47 & 45.76 & 337.1 & 24.1 & 0.2 & & & & & \\
\hline Hole 583B & & & & & & & & & & \\
\hline $1-3,18-20$ & 3.19 & 0.90 & 126.6 & 39.4 & 7.9 & & & & & \\
\hline $1-3,21-23$ & 3.22 & 10.28 & 102.8 & 42.9 & 0.5 & & & & & \\
\hline $1-3,40-42$ & 3.41 & 17.14 & 73.1 & 41.3 & 1.1 & & & & & \\
\hline $2-1,136-138$ & 6.37 & 14.60 & 276.6 & 37.9 & 1.5 & 331.2 & 57.4 & 142.4 & 87.8 & 48 \\
\hline $2-1,140-142$ & 6.41 & 5.73 & 293.6 & 33.4 & 1.9 & 334.0 & 43.1 & 125.4 & 85.0 & 48 \\
\hline $2-2,29-31$ & 6.80 & 99.39 & 298.8 & -4.0 & 0.7 & 306.5 & 24.9 & 134.2 & 126.5 & 48 \\
\hline
\end{tabular}


Table 2. (Continued).

\begin{tabular}{|c|c|c|c|c|c|c|c|c|c|c|}
\hline \multirow[b]{2}{*}{$\begin{array}{l}\text { Core-Section } \\
\text { (interval in } \mathrm{cm} \text { ) }\end{array}$} & \multirow[b]{2}{*}{$\begin{array}{l}\text { Sub-bottom } \\
\text { depth }(m)\end{array}$} & \multirow[b]{2}{*}{$\begin{array}{c}\text { Intensity } \\
\left(\times 10^{-3} \mathrm{~A} / \mathrm{m}\right)\end{array}$} & \multirow[b]{2}{*}{$\begin{array}{c}\text { Relative } \\
\text { decl. } \\
\text { (degrees) }\end{array}$} & \multirow[b]{2}{*}{$\begin{array}{c}\text { Incl. } \\
\text { (degrees) }\end{array}$} & \multirow[b]{2}{*}{$\begin{array}{c}\text { Error } \\
\text { in incl. } \\
\text { (degrees) }\end{array}$} & \multirow{2}{*}{\multicolumn{2}{|c|}{$\begin{array}{l}\text { Relative } \\
\text { Decl. Incl. } \\
\text { (tilt corr.) }\end{array}$}} & & \multicolumn{2}{|c|}{ Bedding dip } \\
\hline & & & & & & & & & $\begin{array}{l}\text { Azimuth } \\
\text { (tilt corr.) } \\
\text { (degrees) }\end{array}$ & Dip \\
\hline Hole 583B (Cont.) & & & & & & & & & & \\
\hline $2-2,36-38$ & 6.87 & 106.95 & 295.3 & 11.4 & 0.9 & 315.5 & 38.7 & 137.7 & 117.5 & 48 \\
\hline $2-3,36-38$ & 8.37 & 0.69 & 290.0 & 8.2 & 2.8 & 307.7 & 39.9 & 143.0 & 125.3 & 48 \\
\hline $3-2,12-14$ & 11.63 & 8.52 & 102.1 & 29.7 & 1.3 & 121.9 & 66.7 & 169.9 & 150.1 & 40 \\
\hline $3-2,29-31$ & 11.80 & 1.27 & 112.8 & 20.2 & 2.5 & 130.9 & 53.8 & 159.2 & 141.1 & 40 \\
\hline $3-3,65-67$ & 13.66 & 19.91 & 135.7 & 30.6 & 0.6 & 161.6 & 56.4 & 151.3 & 125.4 & 36 \\
\hline $3-3,71-73$ & 13.72 & 0.72 & 139.8 & 43.0 & 6.7 & 183.6 & 63.1 & 147.2 & 103.4 & 36 \\
\hline $3-4,37-39$ & 14.88 & 0.60 & 306.2 & 17.1 & 7.9 & & & & & \\
\hline $4-1,80-82$ & 15.81 & 7.73 & 22.3 & 13.8 & 0.5 & 5.9 & 40.4 & 226.7 & 243.2 & 40 \\
\hline $4-2,5-7$ & 16.56 & 39.72 & 66.0 & 8.6 & 0.6 & 68.8 & 43.2 & 177.0 & 174.2 & 35 \\
\hline $4-2,11-13$ & 16.62 & 26.26 & 82.1 & 49.9 & 0.7 & 138.7 & 74.5 & 160.9 & 104.3 & 35 \\
\hline $4-2,16-18$ & 16.67 & 25.67 & 71.0 & 42.5 & 1.2 & 97.6 & 74.9 & 172.0 & 145.4 & 35 \\
\hline $4-3,85-87$ & 18.86 & 39.01 & 89.9 & -0.1 & 0.7 & 100.7 & 32.4 & 142.1 & 131.3 & 47 \\
\hline $4-3,105-107$ & 19.06 & 62.94 & 90.7 & 6.4 & 1.1 & 106.2 & 36.9 & 141.3 & 125.8 & 47 \\
\hline $4-3,119-121$ & 19.20 & 40.59 & 90.2 & 12.6 & 0.8 & 110.9 & 42.0 & 141.8 & 121.1 & 47 \\
\hline $5-1,91-93$ & 20.92 & 29.39 & 205.6 & 8.3 & 1.3 & 226.3 & 47.6 & 151.4 & 130.7 & 52 \\
\hline $5-2,79-81$ & 22.30 & 102.52 & 198.6 & -4.5 & 0.7 & 206.6 & 32.6 & 149.4 & 141.4 & 47 \\
\hline $5-2,91-93$ & 22.42 & 89.09 & 182.2 & 12.3 & 0.4 & 197.1 & 55.1 & 165.8 & 150.9 & 47 \\
\hline $5-3,45-47$ & 23.46 & 76.75 & 208.6 & -19.9 & 0.4 & 208.3 & 19.1 & 141.4 & 141.7 & 52 \\
\hline $5-4,18-20$ & 24.69 & 95.41 & 202.6 & -10.9 & 0.7 & 208.8 & 32.4 & 152.4 & 146.2 & 52 \\
\hline $5-4,22-24$ & 24.73 & 54.51 & 196.2 & -15.4 & 1.1 & 199.8 & 31.2 & 158.8 & 155.2 & 52 \\
\hline $5-4,27-29$ & 24.78 & 29.00 & 193.8 & 5.3 & 1.0 & 209.4 & 50.7 & 161.2 & 145.6 & 52 \\
\hline Hole $583 \mathrm{C}$ & & & & & & & & & & \\
\hline $2-3,51-53$ & 33.52 & 2.46 & 39.9 & 23.1 & 1.2 & 297.2 & 69.3 & 204.1 & 306.8 & 77 \\
\hline $2-3,58-60$ & 33.59 & 2.63 & 28.3 & 1.2 & 2.1 & 25.5 & 40.6 & 193.7 & 196.5 & 40 \\
\hline $3-2,77-79$ & 37.28 & 16.50 & 286.8 & 2.5 & 1.5 & 298.2 & 42.6 & 157.2 & 145.8 & 47 \\
\hline $3-3,25-27$ & 38.26 & 89.46 & 295.6 & 29.9 & 1.5 & 351.4 & 48.9 & 137.4 & 81.6 & 61 \\
\hline $3-8,48-50$ & 38.49 & 60.46 & 304.0 & 2.8 & 0.6 & 317.1 & 41.0 & 152.0 & 138.9 & 48 \\
\hline $5-1,132-134$ & 46.33 & 4.96 & 186.7 & -23.0 & 0.8 & & & & & \\
\hline $5-2,129-131$ & 47.80 & 2.10 & 343.0 & 14.7 & 2.8 & 299.3 & 51.2 & 225.0 & 268.7 & 66 \\
\hline Hole 583D & & & & & & & & & & \\
\hline $3-1,56-58$ & 66.57 & 0.57 & 226.2 & 0.2 & 6.8 & & & & & \\
\hline $4-1,71-73$ & 76.32 & 2.35 & 139.1 & 49.8 & 3.1 & & & & & \\
\hline $6-1,111-113$ & 96.12 & 4.07 & 292.1 & 19.2 & 1.6 & & & & & \\
\hline $6-2,20-22$ & 96.71 & 13.79 & 257.8 & -21.5 & 1.7 & & & & & \\
\hline $6-2,100-102$ & 97.51 & 66.75 & 137.7 & 62.7 & 1.8 & & & & & \\
\hline $6-3,20-22$ & 98.21 & 17.89 & 146.8 & 11.2 & 1.0 & & & & & \\
\hline $8-1,60-62$ & 114.81 & 27.76 & 40.0 & -0.3 & 1.2 & & & & & \\
\hline $9-1,81-83$ & 124.52 & 8.41 & 230.7 & 19.3 & 1.0 & 239.3 & 1.1 & 78.3 & 69.7 & 48 \\
\hline $9-1,134-136$ & 125.05 & 6.40 & 119.1 & 31.6 & 3.4 & & & & & \\
\hline $9-2,117-119$ & 126.38 & 17.17 & 54.9 & 3.3 & 2.1 & 51.8 & 26.8 & 209.1 & 212.2 & 26 \\
\hline $9-2,124-126$ & 126.45 & 16.06 & 102.4 & 24.0 & 1.0 & 111.3 & 47.2 & 161.6 & 152.7 & 26 \\
\hline $9-3,132-134$ & 128.03 & 23.94 & 318.8 & 20.2 & 0.9 & 318.7 & -1.8 & 3.2 & 3.3 & 22 \\
\hline $10-1,49-51$ & 133.70 & 12.30 & 206.6 & 39.5 & 0.5 & 202.8 & 43.8 & 227.4 & 231.2 & 6 \\
\hline $11-1,74-76$ & 143.65 & 12.10 & 9.7 & 51.2 & 1.3 & & & & & \\
\hline $11-1,135-137$ & 144.26 & 6.75 & 32.5 & 62.9 & 1.1 & 22.9 & 58.4 & 310.5 & 320.1 & 7 \\
\hline $12-1,129-131$ & 153.90 & 34.86 & 139.1 & 16.8 & 4.1 & 137.7 & -11.4 & 317.9 & 319.3 & 40 \\
\hline $12-2,86-88$ & 154.97 & 7.55 & 114.2 & 46.5 & 1.3 & 93.6 & 13.6 & 307.8 & 328.4 & 46 \\
\hline $13-1,43-45$ & 162.74 & 6.83 & 159.0 & 22.4 & 1.5 & & & & & \\
\hline $13-2,43-45$ & 163.24 & 12.05 & 13.7 & 22.6 & 1.0 & & & & & \\
\hline $14-2,42-44$ & 173.93 & 18.88 & 252.9 & 37.9 & 1.5 & 256.5 & 42.1 & 141.1 & 137.5 & 6 \\
\hline $14-4,36-38$ & 176.87 & 37.64 & 29.3 & 40.7 & 0.6 & 29.8 & 41.5 & 151.7 & 151.2 & 1 \\
\hline $17-2,59-61$ & 203.10 & 38.12 & 296.1 & 61.7 & 1.2 & 279.0 & 48.0 & 314.9 & 332.0 & 18 \\
\hline $19-1,36-38$ & 220.57 & 78.23 & 130.5 & 77.8 & 1.4 & 94.9 & 56.4 & 311.5 & 347.1 & 25 \\
\hline $19-2,13-15$ & 221.84 & 58.06 & 332.6 & 29.0 & 1.1 & & & & & \\
\hline $19-2,64-66$ & 222.35 & 165.94 & 102.7 & 54.1 & 1.2 & 101.6 & 33.1 & 1.3 & 2.4 & 21 \\
\hline $22-1,77-79$ & 250.08 & 29.23 & 219.9 & 32.3 & 1.5 & 218.0 & 7.9 & 352.1 & 354.0 & 25 \\
\hline $22-2,121-123$ & 252.02 & 36.08 & 231.2 & 53.9 & 1.9 & & & & & \\
\hline $22-3,47-49$ & 252.78 & 20.03 & 139.0 & 58.3 & 0.6 & & & & & \\
\hline $22-3,110-112$ & 253.41 & 8.42 & 127.8 & 75.1 & 1.8 & 103.9 & 66.3 & 309.2 & 333.1 & 12 \\
\hline $22-4,67-69$ & 254.48 & 4.62 & 344.9 & 40.8 & 1.6 & & & & & \\
\hline $22-4,70-72$ & 254.51 & 12.68 & 37.3 & 34.2 & 2.4 & & & & & \\
\hline $22-5,61-63$ & 255.92 & 11.05 & 261.9 & -47.0 & 1.1 & & & & & \\
\hline $22-5,68-70$ & 255.99 & 36.34 & 151.8 & 52.7 & 0.7 & & & & & \\
\hline $22-6,49-51$ & 257.30 & 33.79 & 262.6 & 55.9 & 1.2 & & & & & \\
\hline $23-1,103-105$ & 260.04 & 72.18 & 251.8 & 35.4 & 1.6 & & & & & \\
\hline $23-2,16-18$ & 260.67 & 15.26 & 111.6 & 74.5 & 1.5 & & & & & \\
\hline $23-2,55-57$ & 261.06 & 29.84 & 305.3 & 72.8 & 0.6 & & & & & \\
\hline $24-1,33-35$ & 269.04 & 47.11 & 226.1 & 38.4 & 1.4 & & & & & \\
\hline $24-2,55-57$ & 270.76 & 25.44 & 145.6 & 51.4 & 0.7 & & & & & \\
\hline
\end{tabular}


Table 2. (Continued).

\begin{tabular}{|c|c|c|c|c|c|c|c|}
\hline & & & & & & & Bedding dip \\
\hline $\begin{array}{l}\text { Core-Section } \\
\text { (interval in cm) }\end{array}$ & $\begin{array}{l}\text { Sub-bottom } \\
\text { depth }(m)\end{array}$ & $\begin{array}{c}\text { Intensity } \\
\left(\times 10^{-3} \mathrm{~A} / \mathrm{m}\right)\end{array}$ & $\begin{array}{c}\text { Relative } \\
\text { decl. } \\
\text { (degrees) }\end{array}$ & $\begin{array}{c}\text { Incl. } \\
\text { (degrees) }\end{array}$ & $\begin{array}{c}\text { Error } \\
\text { in incl. } \\
\text { (degrees) }\end{array}$ & $\begin{array}{l}\text { Relative } \\
\text { Decl. Incl. } \\
\text { (tilt corr.) }\end{array}$ & $\begin{array}{l}\text { Azimuth } \\
\text { (tilt corr.) Dip } \\
\text { (degrees) }\end{array}$ \\
\hline
\end{tabular}

Hole 583D (Cont.)

$\begin{array}{lrrrrr}24-3,15-17 & 271.86 & 30.03 & 261.6 & 35.3 & 1.5 \\ 24-4,37-39 & 273.58 & 25.29 & 230.0 & 26.4 & 1.4 \\ 24-6,54-56 & 276.75 & 21.89 & 282.6 & 32.8 & 1.5 \\ 25-1,87-89 & 279.28 & 56.99 & 198.9 & 78.2 & 0.5 \\ 25-2,81-83 & 280.72 & 56.97 & 236.7 & 70.0 & 1.2 \\ 29-1,126-128 & 318.17 & 13.11 & 41.5 & 69.2 & 1.4 \\ 29-2,6-8 & 318.47 & 37.49 & 256.6 & 52.3 & 1.4 \\ 29-2,40-42 & 318.81 & 12.39 & 275.6 & 61.9 & 1.5 \\ 29-2,51-53 & 318.92 & 16.13 & 151.5 & 72.7 & 0.8 \\ 29-2,77-79 & 319.18 & 41.45 & 342.6 & 55.6 & 0.5 \\ 29-2,103-105 & 319.44 & 22.37 & 190.1 & 61.8 & 0.5 \\ 29-3,16-18 & 320.07 & 29.37 & 296.0 & 55.7 & 1.5 \\ 29-3,114-116 & 321.05 & 24.30 & 41.9 & 70.9 & 0.9 \\ 29-3,123-125 & 321.14 & 11.15 & 207.3 & 74.9 & 1.8\end{array}$

Hole $583 \mathrm{~F}$

$\begin{array}{ll}6-2,63-65 & 200.84 \\ 6-2,77-79 & 200.98 \\ 12-1,45-47 & 256.76 \\ 12-1,62-64 & 256.93 \\ 12-1,118-120 & 257.49 \\ 12-2,41-43 & 258.22 \\ 12-2,55-57 & 258.36 \\ 12-2,114-116 & 258.95 \\ 12-2,120-122 & 259.01 \\ 12-3,6-8 & 259.37 \\ 12-3,35-37 & 259.66 \\ 14-2,7-9 & 275.78 \\ 14-1,68-70 & 276.39 \\ 15-1,72-74 & 286.13 \\ 16-1,78-80 & 295.79 \\ 16-1,92-94 & 295.93 \\ 16-2,10-12 & 296.61 \\ 17-1,21-23 & 304.82 \\ 17-2,2-4 & 306.13 \\ 17-2,22-24 & 306.33 \\ 18-1,60-62 & 314.81 \\ 18-1,78-80 & 314.99 \\ 18-1,90-92 & 315.11 \\ 18-1,109-111 & 315.30 \\ 18-2,114-116 & 316.85 \\ 18-3,45-47 & 317.66 \\ 18-4,1-3 & 318.72 \\ 19-1,47-49 & 324.38 \\ 19-1,75-77 & 324.66 \\ 19-1,80-82 & 324.71 \\ 20-1,39-41 & 334.00 \\ 20-1,48-50 & 334.09 \\ 22-1,63-65 & 353.54 \\ 22-2,63-65 & 355.04 \\ 24-1,126-128 & 373.37 \\ 24-2,25-27 & 373.86 \\ 24-3,18-20 & 375.29 \\ 24-5,22-24 & 378.33 \\ 25-1,87-89 & 382.68 \\ 26-1,87-89 & 392.38 \\ 26-3,58-60 & 395.09 \\ 27-2,31-33 & 403.02 \\ 28-1,59-61 & 411.40 \\ 29-2,32-34 & 422.23\end{array}$

\begin{tabular}{rrrr}
14.44 & 236.3 & 48.6 & 1.6 \\
26.34 & 229.3 & 32.5 & 0.9 \\
16.19 & 153.6 & 52.2 & 0.6 \\
40.52 & 359.2 & 38.0 & 0.4 \\
56.26 & 353.6 & 30.1 & 0.1 \\
69.65 & 312.5 & 41.1 & 0.7 \\
149.10 & 39.7 & 31.2 & 0.7 \\
2.81 & 223.8 & 63.5 & 2.3 \\
1.55 & 205.4 & 32.9 & 7.1 \\
46.07 & 314.0 & 30.7 & 0.8 \\
78.33 & 251.0 & 18.6 & 0.7 \\
22.26 & 214.3 & 57.4 & 1.2 \\
54.62 & 13.5 & 48.7 & 0.6 \\
26.67 & 284.4 & 37.2 & 0.8 \\
24.11 & 278.8 & 26.5 & 1.1 \\
72.60 & 45.4 & 50.1 & 0.6 \\
29.57 & 220.5 & 42.8 & 1.6 \\
9.16 & 55.0 & 54.0 & 1.4 \\
21.47 & 247.5 & 63.7 & 0.9 \\
20.28 & 131.7 & 39.4 & 0.6 \\
23.38 & 83.8 & 39.1 & 1.1 \\
79.22 & 98.6 & 15.8 & 1.2 \\
62.36 & 229.2 & 36.5 & 0.5 \\
54.83 & 296.0 & 27.8 & 2.4 \\
43.91 & 8.0 & 45.7 & 0.5 \\
8.34 & 344.5 & 15.1 & 0.1 \\
21.57 & 94.6 & 47.2 & 1.0 \\
24.13 & 93.9 & 37.1 & 1.1 \\
36.37 & 6.0 & 22.4 & 0.6 \\
51.82 & 146.4 & 25.3 & 0.3 \\
16.23 & 93.4 & 40.9 & 0.6 \\
13.21 & 233.8 & 43.5 & 1.4 \\
57.80 & 344.8 & 40.7 & 1.1 \\
36.52 & 23.3 & 77.5 & 2.3 \\
34.20 & 48.4 & 39.0 & 3.0 \\
35.10 & 307.5 & 47.5 & 1.4 \\
73.51 & 278.9 & 42.7 & 1.0 \\
92.42 & 293.9 & 38.3 & 0.8 \\
22.64 & 234.0 & 46.3 & 4.5 \\
22.01 & 340.2 & 40.3 & 1.4 \\
30.49 & 64.9 & 37.0 & 1.8 \\
25.57 & 282.1 & 22.7 & 0.7 \\
5.44 & 40.3 & 43.8 & 3.6 \\
26.64 & 16.2 & 39.3 & 0.5 \\
& & & \\
\hline & & &
\end{tabular}

Hole 583G

$\begin{array}{ll}1-1,27-29 & 306.88 \\ 1-2,60-62 & 308.71 \\ 1-3,70-72 & 310.31 \\ 2-2,122-124 & 318.93 \\ 2-3,112-114 & 320.33 \\ 3-3,129-131 & 330.20 \\ 4-2,37-39 & 337.48 \\ 4-3,133-135 & 339.94 \\ 4-4,75-77 & 340.86\end{array}$

19.68
4.49
22.20
41.61
9.35
9.52
41.27
37.97

78.5
192.0
53.4
162.7
62.0
82.1
203.4
121.2
92.0

$\begin{array}{ll}52.1 & 1.7 \\ 44.8 & 1.6 \\ 18.9 & 1.9 \\ 50.1 & 0.9 \\ 65.8 & 1.7 \\ 47.2 & 1.9 \\ 44.7 & 1.7 \\ 38.8 & 1.3 \\ 28.4 & 0.8\end{array}$


Table 2. (Continued).

\begin{tabular}{|c|c|c|c|c|c|c|c|c|c|c|}
\hline \multirow[b]{2}{*}{$\begin{array}{l}\text { Core-Section } \\
\text { (interval in } \mathrm{cm} \text { ) }\end{array}$} & \multirow[b]{2}{*}{$\begin{array}{l}\text { Sub-bottom } \\
\text { depth (m) }\end{array}$} & \multirow[b]{2}{*}{$\begin{array}{c}\text { Intensity } \\
\left(\times 10^{-3} \mathrm{~A} / \mathrm{m}\right)\end{array}$} & \multirow[b]{2}{*}{$\begin{array}{c}\text { Relative } \\
\text { decl. } \\
\text { (degrees) }\end{array}$} & \multirow[b]{2}{*}{$\begin{array}{c}\text { Incl. } \\
\text { (degrees) }\end{array}$} & \multirow[b]{2}{*}{$\begin{array}{c}\text { Error } \\
\text { in incl. } \\
\text { (degrees) }\end{array}$} & \multirow[b]{2}{*}{$\begin{array}{l}\text { Relative } \\
\text { Decl. } \\
\text { (tilt corr }\end{array}$} & \multirow[b]{2}{*}{$\begin{array}{l}\text { Incl. } \\
\text { r.) }\end{array}$} & & \multicolumn{2}{|c|}{ Bedding dip } \\
\hline & & & & & & & & & $\begin{array}{l}\text { Azimuth } \\
\text { (tilt corr.) } \\
\text { (degrees) }\end{array}$ & Dip \\
\hline \multicolumn{11}{|l|}{ Hole 583G (Cont.) } \\
\hline $5-1,125-127$ & 346.56 & 5.49 & 338.7 & 25.0 & 1.5 & & & & & \\
\hline $5-2,115-117$ & 347.96 & 2.64 & 228.4 & 43.0 & 5.3 & & & & & \\
\hline $6-3,46-48$ & 358.47 & 27.34 & 199.7 & 22.6 & 0.4 & & & & & \\
\hline $7-2,51-53$ & 366.72 & 13.04 & 339.9 & 36.4 & 0.8 & 331.6 & 6.5 & 326.1 & 334.4 & 36 \\
\hline $7-3,8-10$ & 367.79 & 6.86 & 303.5 & 34.2 & 0.9 & & & & & \\
\hline $7-4,80-82$ & 370.01 & 25.54 & 232.1 & 43.8 & 1.7 & & & & & \\
\hline $8-2,20-22$ & 376.11 & 36.05 & 54.0 & 46.5 & 0.9 & & & & & \\
\hline $8-3,2-4$ & 377.43 & 25.20 & 356.9 & 27.4 & 0.6 & & & & & \\
\hline $10-4,69-71$ & 399.00 & 19.92 & 82.7 & 21.1 & 0.9 & 81.9 & 0.5 & 353.3 & 354.1 & 21 \\
\hline $10-4,100-102$ & 399.31 & 8.97 & 302.6 & 24.2 & 0.8 & 289.6 & 1.6 & 290.4 & 303.4 & 56 \\
\hline $10-5,84-86$ & 400.65 & 13.78 & 19.7 & 13.2 & 0.4 & 50.0 & 52.3 & 150.3 & 120.0 & 56 \\
\hline $11-2,40-42$ & 405.41 & 7.56 & 311.3 & 43.0 & 1.0 & & & & & \\
\hline $15-1,65-67$ & 442.66 & 18.65 & 126.0 & 42.6 & 1.2 & & & & & \\
\hline $15-2,66-68$ & 444.17 & 43.17 & 129.8 & 39.2 & 1.6 & & & & & \\
\hline \multicolumn{11}{|l|}{ Hole $583 \mathrm{H}$} \\
\hline $3-3,17-19$ & 232.38 & 22.88 & 27.8 & 18.2 & 1.2 & & & & & \\
\hline $3-3,135-137$ & 233.56 & 4.67 & 12.6 & -67.1 & 1.7 & & & & & \\
\hline $3-4,73-75$ & 234.44 & 17.22 & 36.8 & 17.0 & 1.6 & & & & & \\
\hline $3-5,7-9$ & 235.28 & 26.58 & 116.1 & 46.0 & 1.2 & & & & & \\
\hline $3-5,117-119$ & 236.38 & 47.94 & 42.9 & 41.0 & 1.7 & & & & & \\
\hline $3-6,44-46$ & 237.15 & 21.42 & 152.9 & 45.6 & 0.6 & & & & & \\
\hline $4-1,44-46$ & 259.36 & 60.29 & 345.7 & 33.2 & 0.4 & & & & & \\
\hline $4-2,23-25$ & 259.74 & 30.33 & 183.8 & 41.7 & 1.6 & & & & & \\
\hline $4-3,109-111$ & 262.10 & 47.32 & 262.4 & 45.8 & 0.0 & & & & & \\
\hline $5-1,97-99$ & 288.38 & 25.26 & 209.9 & 55.9 & 1.4 & & & & & \\
\hline $5-3,130-132$ & 291.71 & 54.99 & 184.2 & 46.6 & 1.9 & & & & & \\
\hline
\end{tabular}

Note: decl. = declination; incl. = inclination; corr. = correction .

Site 582 on the trough floor. If plate motion is taken into account (Minster and Jordan, 1979), the paleoposition of Site 583 was the same as the paleoposition of Site 582 before $0.15 \mathrm{Ma}$ (Fig. 6). If there was a difference in depositional conditions at that relative position in the trough, a change in the character of the sediments should have appeared first at Site 583 and then $0.15 \mathrm{Ma}$ later at Site 582. Because an uppermost zone of weak intensity of remanent magnetization was determined both for Holes 583A and 583 and for Hole 582 (Figs. 3, 8, 9, $10)$, the change in intensity is explained by the changes in the sediment supply, not by changes in the relative positions of the sites in the trough.

In Holes 583B, 583C, 583D, and the lower part of Hole $583 \mathrm{G}$, strata are tilted. The dip of the bedding planes was measured for the hydraulic piston cores by a Kuster device (Lundberg and Karig, this volume), but few of those cores were oriented, and this method cannot be applied to ordinary rotary cores. I attempted to orient bedding and fault planes using paleomagnetic declination. The principle is essentially the same as in using a magnetic compass on land; the only difference is in the focus on the past instead of the present geomagnetic field. Orientation is possible from the declination of remanent magnetization, after correction for the dip of bedding planes and for the dip direction of bedding against the core tube, assuming that (1) the geomagnetic declination is $0^{\circ}$ (due north) in the normal field and $180^{\circ}$ (due south) in the reversed field; (2) geomagnetic polarity is determined by the inclination of remanent magneti- zation; (3) the drilling axis is vertical; and (4) fold axes are horizontal. The average of the positive inclinations measured and corrected for tilt in Holes 583B, 583C, and 583D (Fig. 12) is significantly shallower than the inclination of the geocentric axial dipole field estimated in Holes 583, 583A, and 583F; however, most of the original remanent magnetization has been maintained after tectonic disturbance. In Holes 583B, 583C, 583D, and $583 \mathrm{G}$, the orientation of bedding planes determined by paleomagnetic direction shows a concentration of bedding-dip azimuth to the southeast and, to a much lesser extent, to the northwest (Table 3; Fig. 13). Because the directions are more nearly parallel to the direction of the relative motion of the Philippine Sea Plate (Minster and Jordan, 1979) than perpendicular to the axis of the Nankai Trough, plate motion is a likely cause of the tilting. Figure 14 is a columnar section showing the attitude of the strata, together with dip and dip azimuth for the restored sections for Holes 583B, 583C, and 583D.

In Holes 583B, 583C, and 583D, not all measurements in tilted sediments are directly related to the tectonic data (Lundberg and Karig, this volume). Some horizons for paleomagnetic measurements are separated from the portions of bedding-dip measurements by drilling disturbance. Because the magnetic direction before bedding correction is a result of both the direction of the geomagnetic field in which the sediments accumulated and the tilt of the bedding plane, we can use the inclination before bedding correction to reconstruct tectonic disturbance (Fig. 14). Above $130 \mathrm{~m}$ sub-bottom, 


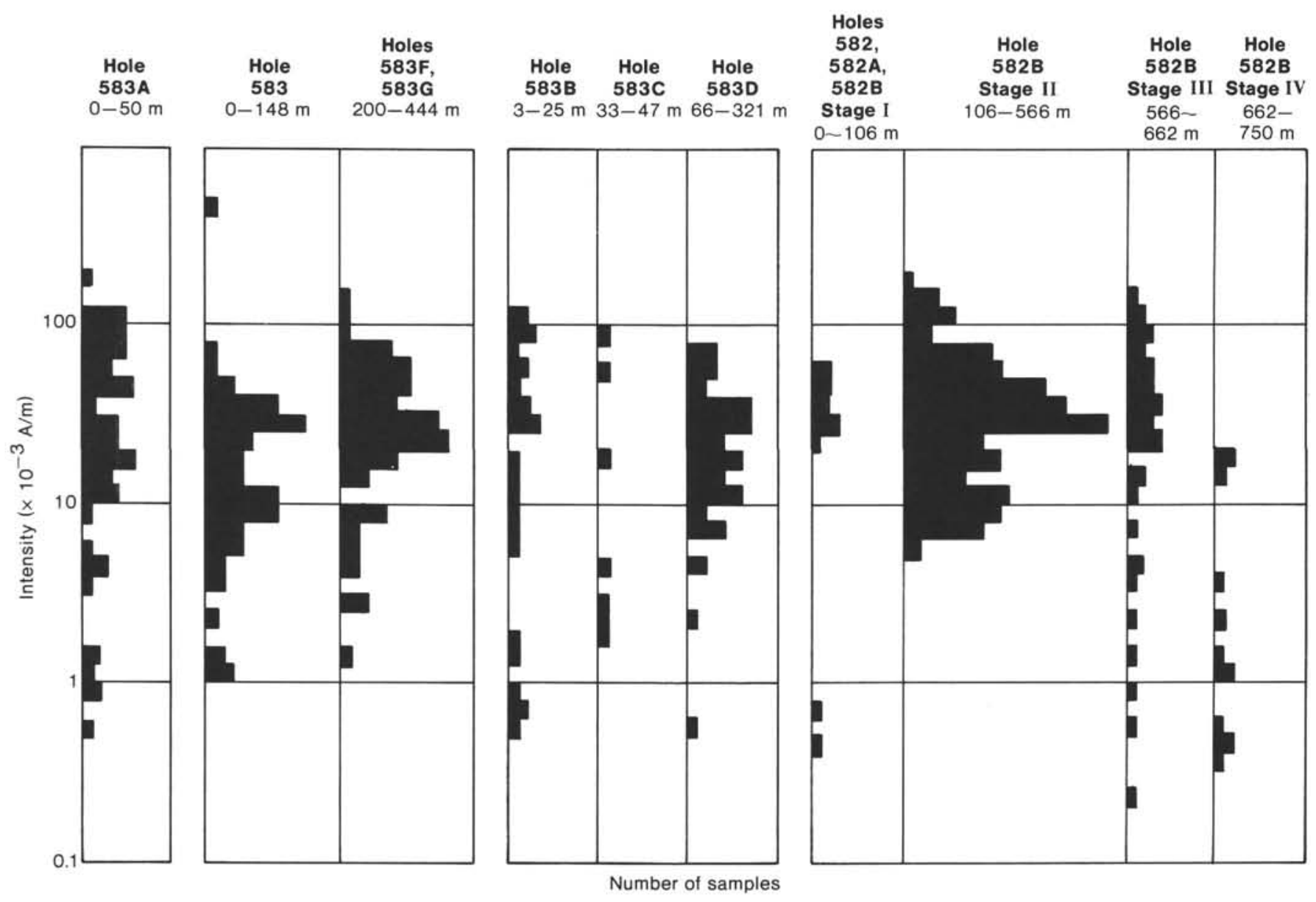

Figure 11. Frequency distribution of intensities of remanent magnetization after 15-mT AF demagnetization for samples from Sites 582 and 583.

inclinations are shallow or negative, in contrast to steep positive inclinations below the $130-\mathrm{m}$ level. The changes in inclination result from changes in the direction of tilting, southeastward dipping above $130 \mathrm{~m}$ sub-bottom and northwestward dipping below that level. Inclination of the nonoriented samples also follows the same general tendency. The distribution of the dip azimuths is consistent with the disposition of reflectors on seismic profiles (Kagami et al., this volume).

Several faults in Hole $583 \mathrm{G}$ were also oriented in the manner just described (Table 4; Fig. 15). The steps on striations indicate that the faults are normal, and striations on the slickensides parallel the dip direction. Conjugate fault sets occur at 377.4 and $399.3 \mathrm{~m}$ sub-bottom. The maximum-stress axis is vertical and the minimumstress (tensional-stress) axis is horizontal and parallel to the direction of the relative motion of the Philippine Sea Plate (Fig. 16). The faults were probably created when stress from plate motion was released in an anticlinal crest.

Although sediment is also tilted at 366.7 and $400.7 \mathrm{~m}$ sub-bottom in Hole 583G, layers around these horizons are subhorizontal, indicating that the tilt was caused by the intraformational deformation. That deformation is accompanied by one of the conjugate fault sets already mentioned. The other fault set cuts the subhorizontal strata. Turbiditic sand layers more than $1 \mathrm{~m}$ thick at
$366.7 \mathrm{~m}$ sub-bottom and $40 \mathrm{~cm}$ thick at $400.7 \mathrm{~m}$ are involved in the deformation. The top of the upper sand layer includes a siderite nodule, probably formed a few hundreds of meters below the seafloor (Matsuhisa and Matsumoto, this volume). Its remanent magnetization was probably acquired after deformation, as indicated by the inclination data (Table 4). These facts suggest that the intraformational deformation is not a simple primary sedimentary structure but was created by the flow of the thick sand layer that was liquefied, and that the deformation was a part of the tectonic disturbance induced by the relative plate motion along the Nankai Trough.

\section{Site 584}

Three holes were drilled and 230 paleomagnetic samples were collected at Site 584 (Table 5; Figs. 17-19). Three major difficulties in the paleomagnetic study for this site are attributable to (1) weak remanent magnetization; (2) tectonic disturbance of the sediments, and (3) remagnetization of the disturbed sediments.

The reactions of the remanent magnetization are distinguished neither in intensity nor direction by AF demagnetization (Fig. 2). The change in magnetic direction induced by AF demagnetization was larger in samples with lower intensity, although it was still less than $15^{\circ}$. The maximum change in direction is in the $5-\mathrm{mT}$ 

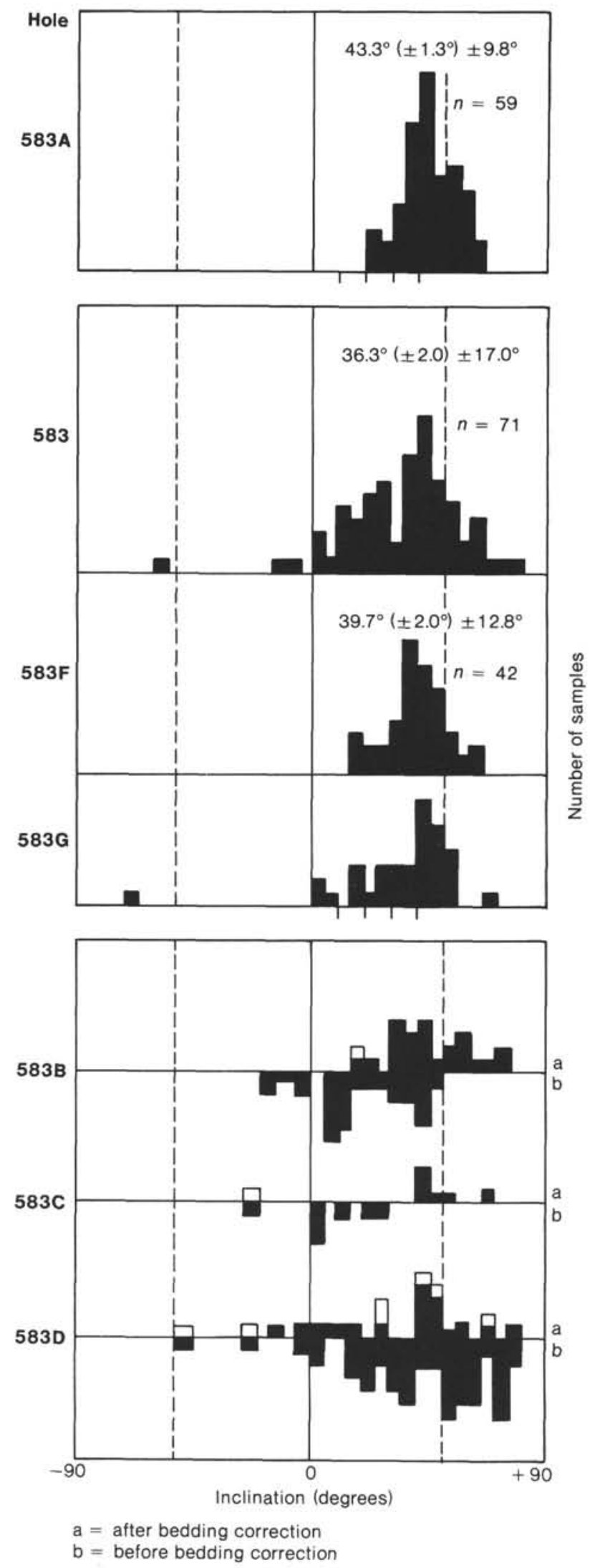

Figure 12. Frequency distribution and statistics (mean, standard error of the mean, and standard deviation) for inclinations at Site 583 . Dotted lines correspond to the inclinations of the geocentric axial dipole field.
Table 3. Bedding orientations in Holes $583 \mathrm{~B}, 583 \mathrm{C}$, and 583D.

\begin{tabular}{crr}
\hline & \multicolumn{2}{c}{ Bedding dip } \\
\cline { 2 - 3 } $\begin{array}{c}\text { Sub-bottom } \\
\text { depth }(\mathrm{m})\end{array}$ & $\begin{array}{c}\text { Azimuth } \\
\text { (degrees) }\end{array}$ \\
\hline & \multicolumn{2}{c}{ Angle } \\
Hole 583B & & \\
& & \\
6.4 & 87.8 & 48 \\
6.4 & 85.0 & 48 \\
6.8 & 126.5 & 48 \\
8.4 & 125.3 & 48 \\
11.6 & 150.1 & 40 \\
11.8 & 141.1 & 40 \\
13.7 & 125.4 & 36 \\
13.7 & 103.4 & 36 \\
15.8 & 243.2 & 40 \\
16.6 & 174.2 & 35 \\
16.6 & 104.3 & 35 \\
16.7 & 145.4 & 35 \\
18.9 & 131.3 & 47 \\
19.1 & 125.8 & 47 \\
19.2 & 121.1 & 47 \\
20.9 & 130.7 & 52 \\
22.3 & 141.4 & 47 \\
22.4 & 150.9 & 47 \\
23.5 & 141.7 & 52 \\
24.7 & 146.2 & 52 \\
24.7 & 155.2 & 52 \\
24.8 & 145.6 & 52 \\
& &
\end{tabular}

Hole $583 \mathrm{C}$

$\begin{array}{rrr}33.5 & 306.8 & 77 \\ 33.6 & 196.5 & 40 \\ 37.3 & 145.8 & 47 \\ 38.3 & 81.6 & 61 \\ 38.5 & 138.9 & 48 \\ 47.8 & 268.7 & 66\end{array}$

Hole 583D

$\begin{array}{rrr}124.5 & 69.7 & 48 \\ 126.4 & 212.2 & 26 \\ 126.5 & 152.7 & 26 \\ 128.0 & 3.3 & 22 \\ 133.7 & 231.2 & 6 \\ 144.3 & 320.1 & 7 \\ 153.9 & 319.3 & 40 \\ 155.0 & 328.4 & 46 \\ 173.9 & 137.5 & 6 \\ 176.9 & 151.2 & 7 \\ 203.1 & 332.0 & 18 \\ 220.6 & 347.1 & 25 \\ 222.4 & 2.4 & 21 \\ 250.1 & 354.0 & 25 \\ 253.4 & 333.1 & 12\end{array}$

and $15-\mathrm{mT}$ steps. All samples were cleaned by $15-\mathrm{mT}$ AF demagnetization.

The intensity of remanent magnetization after 15-mT AF demagnetization increases with sub-bottom depth; it is $2 \times 10^{-4} \mathrm{~A} / \mathrm{m}$ in the upper $180 \mathrm{~m}$ and $5 \times 10^{-4} \mathrm{~A} / \mathrm{m}$ in the lower half (Fig. 20). Weak intensities measured in the upper $180 \mathrm{~m}$ are comparable to the noise level of the magnetometer. The intensities of some samples from the lower half and from the top of the section were as strong as $5 \times 10^{-2}$ and $2 \times 10^{-2} \mathrm{~A} / \mathrm{M}$, respectively. Although measured intensities were generally weak, on the order of $10^{-4} \mathrm{~A} / \mathrm{m}$, strong intensities in limited horizons are useful for stratigraphic correlation.

Distributions of measured inclinations before and after bedding correction are indistinctly bimodal (Fig. 21). 


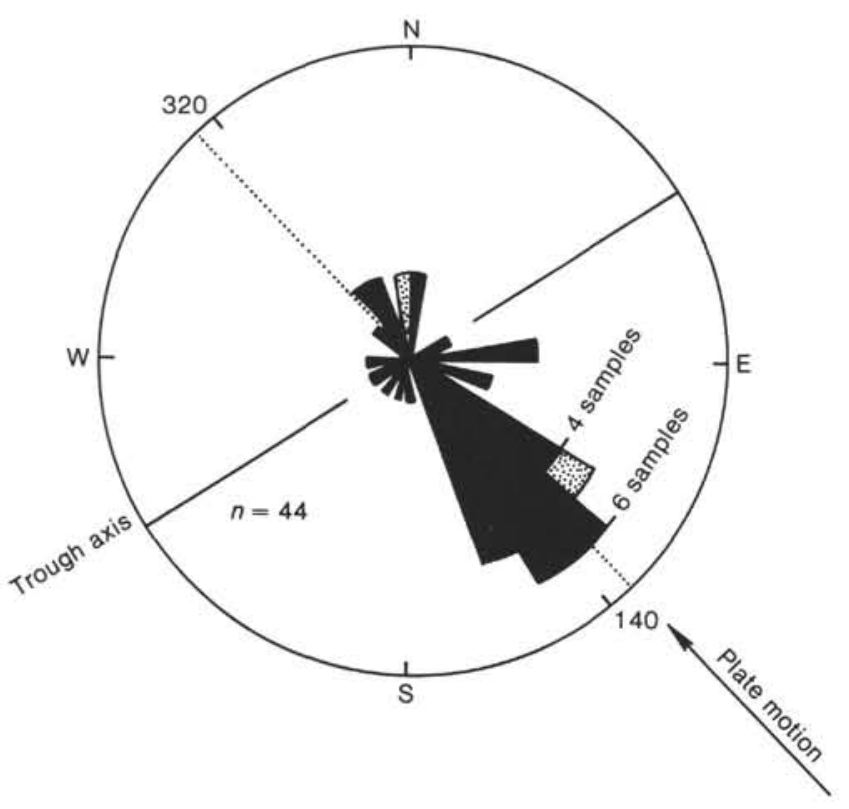

Figure 13. Rose diagram of bedding-dip azimuth in (shaded areas)

Holes 583B, 583C, 583D, and (stippled areas) Hole 583G.

The mode in the negative inclination is broad, and the maximum inclination of $-10^{\circ}$ is very shallow compared with the inclination of the geocentric axial dipole field $\left( \pm 59.6^{\circ}\right)$. There are three possible explanations for this distribution of the inclination: (1) disturbance by machine noise from the magnetometer (except for those in the upper $180 \mathrm{~m}$, the intensities of most samples are strong compared with the noise level of the magnetometer); (2) tectonic disturbance (most of the magnetic samples were taken from horizons where bedding tilt was measured and its relation to the magnetic direction known; and (3) remagnetization after tilting of the bedding plane.

Inclination of remanent magnetization of some samples is the same as that of the geocentric axial dipole field before bedding correction, despite tilting of the sediments. A stereographic projection of the bedding-plane poles, calculated from measured magnetic declination before bedding correction, represents samples with remanent magnetization inclination greater than $50^{\circ}$ before bedding correction, and shallower than $50^{\circ}$ after bedding correction (Fig. 22). The error in inclination (EI) is less than $15^{\circ}$ (Niitsuma, 1971). Here, the beds are sufficiently tilted for determination of magnetic components after and before tilt, and valid EI is an indicator of the reliability of the measured magnetic direction, possibly affected by magnetometer noise and homogeneity of magnetization in the samples.

Bedding planes are tilted eastward in most of the selected samples, and most of the magnetization was probably acquired after tilting. The general direction of bedding tilt at Site 584 was checked by using reversedpolarity samples with negative inclination. Remanent magnetization with negative inclination preserves the original component, and the magnetic overprint should be small in proportion. For this test, I selected samples with negative inclination steeper than $-40^{\circ}$ after bed-
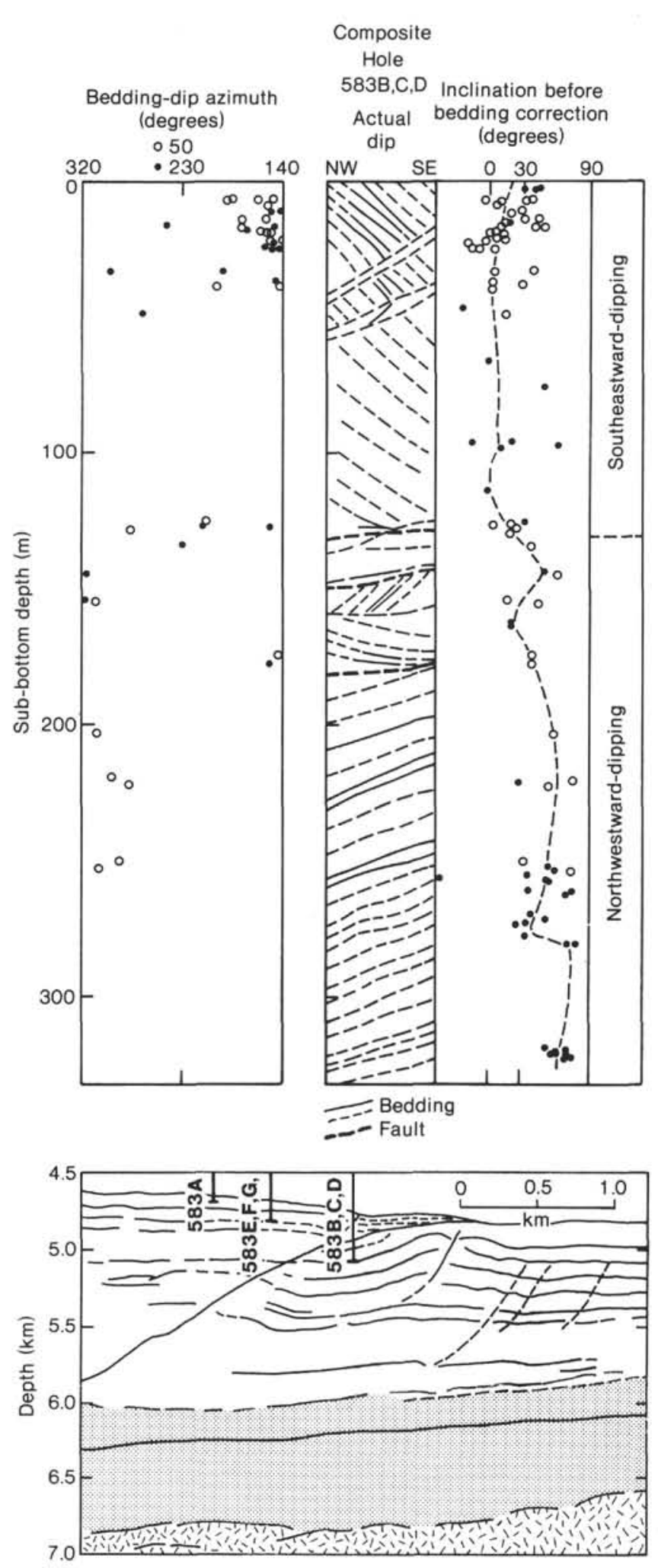

Figure 14. Dip azimuth, schematic cross section, and inclination before bedding correction in Holes 583B, 583C, and 583D, and interpretive cross section based on seismic profile N-55-3-1 (see site chapter, Site 582, this volume). 


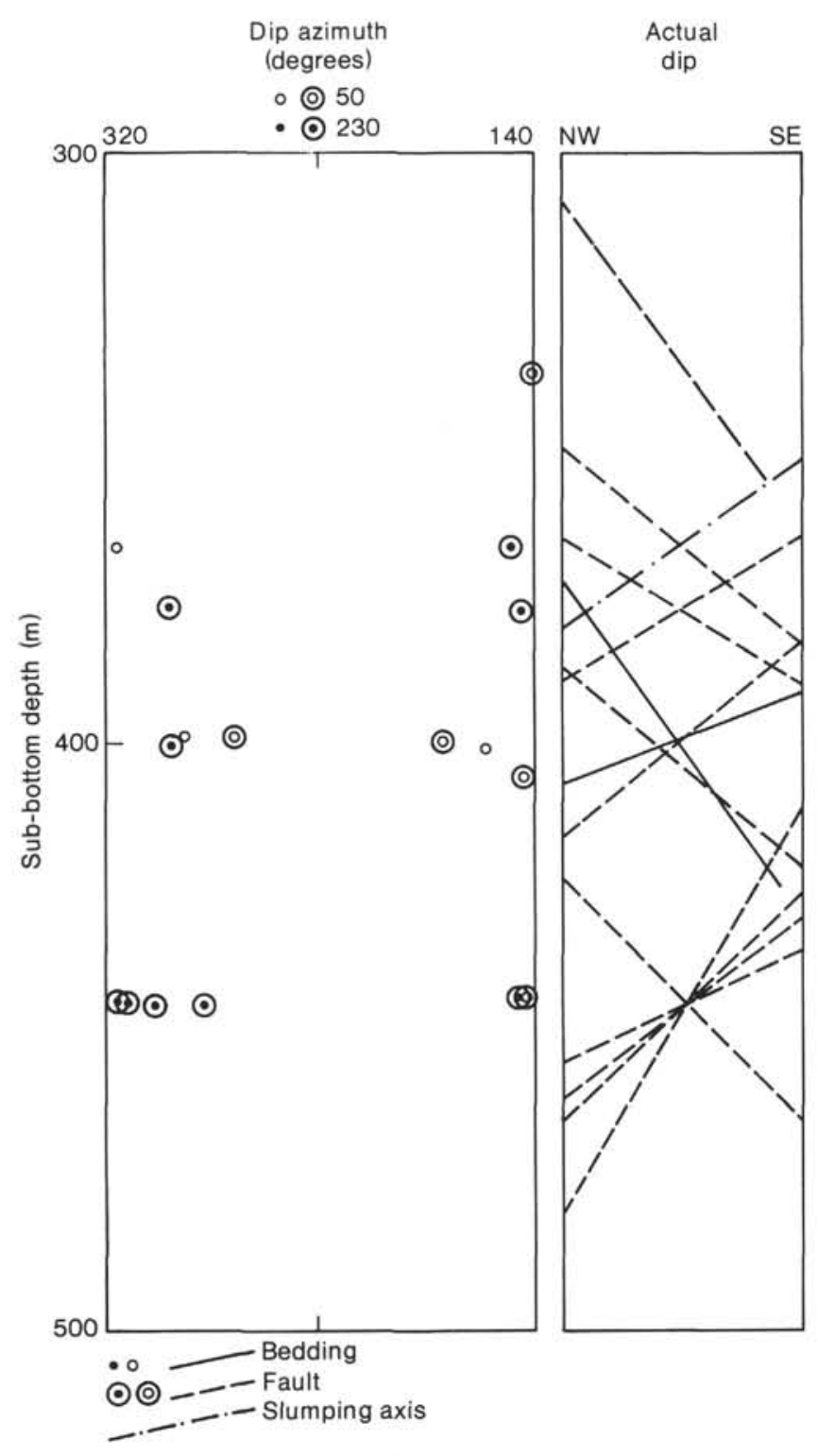

Figure 15. Dip azimuth and dip angle of faults and bedding planes in Hole 583G.

ding correction. With few exceptions, bedding-plane dips for these samples are concentrated in the southeast quadrant (Fig. 23). These data support the bedding-plane tilting directions derived from the measurements of remagnetized samples.

I investigated the hypothesis that remagnetization could explain the pattern of the magnetization record for Site 584 based on the plausible assumptions that (1) bedding planes are tilted eastward; (2) samples were originally magnetized in the normal or reversed geocentric axial dipole magnetic field before tilting; and (3) magnetic overprint parallel to the normal geomagnetic field was acquired after tilting. Using these assumptions, I plotted lines representing the traces of the poles of tilted bedding planes against the magnetic declination of remagnetized sediments for various ratios of a remagnetized component (Figs. 22, 23). The magnetized sediments
Table 4. Faults and bedding planes in Hole 583G.

\begin{tabular}{|c|c|c|c|}
\hline \multirow[b]{2}{*}{$\begin{array}{l}\text { Sub-bottom } \\
\text { depth (m) }\end{array}$} & \multicolumn{2}{|l|}{ Dip } & \multirow[b]{2}{*}{ Comments } \\
\hline & \multicolumn{2}{|c|}{ (degrees) } & \\
\hline 337.5 & 139.4 & 42 & Normal fault: striation $\left(196.5^{\circ}, 42^{\circ}\right)$ \\
\hline 366.7 & 326.1 & 36 & $\begin{array}{l}\text { Bedding plane of siderite slump: } \\
\text { magnetization }\left(339.9^{\circ}, 36^{\circ}\right) \text {; } \\
\text { after bedding correction } \\
\left(331.6^{\circ}, 6.5^{\circ}\right)\end{array}$ \\
\hline 367.8 & 149.6 & 40 & Fault \\
\hline \multirow[t]{2}{*}{377.4} & 292.5 & 32 & Fault \\
\hline & 146.8 & 32 & Fault \\
\hline \multirow[t]{2}{*}{399.0} & 354.9 & 21 & Bedding \\
\hline & 15.8 & 40 & Fault \\
\hline \multirow{2}{*}{399.3} & 101.6 & 36 & Normal fault: striation $\left(88.4^{\circ}, 35^{\circ}\right)$ \\
\hline & 291.4 & 46 & Normal fault: striation $\left(292.3^{\circ}, 38^{\circ}\right)$ \\
\hline 400.7 & 120.0 & 56 & Bedding \\
\hline 405.4 & 135.5 & 40 & Fault \\
\hline \multirow{2}{*}{442.7} & 146.8 & 45 & Fault \\
\hline & 136.9 & 45 & Fault \\
\hline \multirow{4}{*}{444.2} & 313.1 & 45 & Normal fault \\
\hline & 314.4 & 60 & Normal fault \\
\hline & 297.5 & 27 & Normal fault \\
\hline & 277.1 & 38 & Normal fault \\
\hline
\end{tabular}

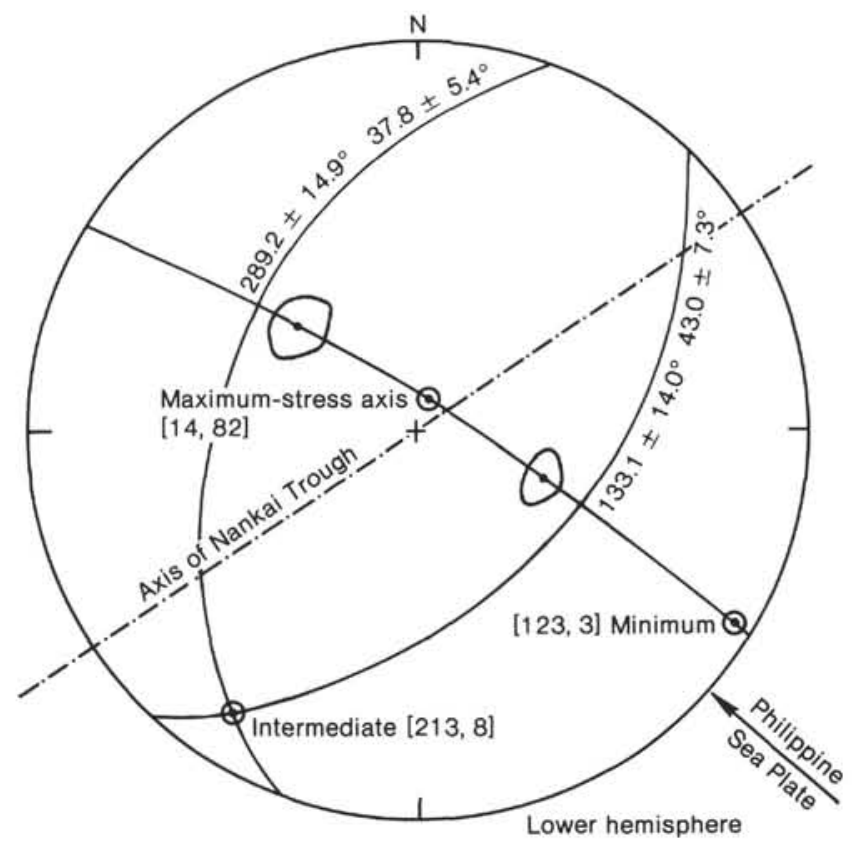

Principal axis
Pole of fault planes

Figure 16. Stress pattern derived from conjugate fault sets in Hole $583 \mathrm{G}$.

were remagnetized to more than twice the magnetization of the original component (Fig. 22), and the reversely magnetized sediments were also remagnetized up to a few tens percent of the original component (Fig. 23). The scatter of samples in the southern portion of Figure 23 is explained by the remagnetization, not by the differences in tilting direction.

The negative inclination of reversely magnetized samples after bedding correction is easily affected by the overprinted component of remanent magnetization, but 
Table 5. Paleomagnetic measurements after $15-\mathrm{mT}$ AF demagnetization at Site 584.

\begin{tabular}{|c|c|c|c|c|c|c|c|}
\hline & & & & & & & Bedding dip \\
\hline $\begin{array}{l}\text { Core-Section } \\
\text { (interval in } \mathrm{cm} \text { ) }\end{array}$ & $\begin{array}{l}\text { Sub-bottom } \\
\text { depth }(m)\end{array}$ & $\begin{array}{c}\text { Intensity } \\
\left(\times 10^{-3} \mathrm{~A} / \mathrm{m}\right)\end{array}$ & $\begin{array}{c}\text { Relative } \\
\text { decl. } \\
\text { (degrees) }\end{array}$ & $\begin{array}{c}\text { Incl. } \\
\text { (degrees) }\end{array}$ & $\begin{array}{l}\text { Error } \\
\text { in incl. } \\
\text { (degrees) }\end{array}$ & $\begin{array}{l}\text { Relative } \\
\text { Decl. Incl. } \\
\text { (tilt corr.) }\end{array}$ & $\begin{array}{l}\text { Azimuth } \\
\text { (tilt corr.) Dip } \\
\quad \text { (degrees) }\end{array}$ \\
\hline
\end{tabular}

Hole 584

\begin{tabular}{|c|c|c|c|c|c|}
\hline $1-1,73-75$ & 0.74 & 10.93 & 208.1 & 17.5 & 1.0 \\
\hline $1-1,137-139$ & 1.38 & 17.66 & 29.8 & 81.4 & 0.9 \\
\hline $1-3,3-5$ & 3.04 & 22.16 & 248.2 & 61.7 & 1.4 \\
\hline $1-3,32-34$ & 3.33 & 0.43 & 305.6 & 44.2 & 10.5 \\
\hline $1-3,112-114$ & 4.13 & 0.12 & 342.7 & 36.9 & 91.4 \\
\hline $1-4,30-32$ & 4.81 & 0.24 & 19.4 & 28.8 & 9.2 \\
\hline $1-4,113-115$ & 5.64 & 0.15 & 187.5 & 68.6 & 33.6 \\
\hline $1-5,24-26$ & 6.25 & 0.28 & 165.8 & 26.9 & 9.1 \\
\hline $1-5,96-98$ & 6.97 & 0.72 & 234.1 & 70.6 & 8.9 \\
\hline $1-6,34-36$ & 7.85 & 0.19 & 219.8 & 62.3 & 23.1 \\
\hline $1-6,103-105$ & 8.54 & 0.33 & 156.5 & 41.6 & 17.8 \\
\hline $2-1,96-98$ & 11.27 & 0.89 & 329.4 & 62.8 & 11.2 \\
\hline $2-2,38-40$ & 12.19 & 0.19 & 349.6 & 22.7 & 46.0 \\
\hline $2-2,113-115$ & 12.94 & 0.07 & 288.1 & 17.7 & 33.8 \\
\hline $2-3,38-40$ & 13.69 & 0.19 & 268.0 & 75.9 & 27.3 \\
\hline $2-3,1123-115$ & 14.44 & 0.21 & 92.4 & 73.7 & 40.2 \\
\hline $2-4,48-50$ & 15.29 & 1.08 & 40.8 & -5.5 & 6.6 \\
\hline $3-1,40-42$ & 20.41 & 0.21 & 34.9 & 7.3 & 29.3 \\
\hline $3-1,66-68$ & 20.67 & 0.16 & 68.8 & 21.9 & 11.7 \\
\hline $3-1,94-96$ & 20.95 & 0.86 & 286.2 & 59.2 & 2.6 \\
\hline $3-2,83-85$ & 22.34 & 0.37 & 82.9 & 58.8 & 25.8 \\
\hline $3-3,95-97$ & 23.96 & 0.41 & 291.6 & 64.7 & 16.1 \\
\hline $3-4,94-96$ & 25.45 & 0.30 & 330.6 & 23.5 & 26.4 \\
\hline $4-1,117-119$ & 30.58 & 0.30 & 287.2 & 28.4 & 5.0 \\
\hline $4-2,113-115$ & 32.04 & 1.31 & 5.3 & 36.1 & 2.5 \\
\hline $4-3,114-116$ & 33.55 & 0.26 & 331.0 & 48.2 & 28.8 \\
\hline $4-4,106-108$ & 34.97 & 0.35 & 262.4 & 81.2 & 17.5 \\
\hline $4-5,72-74$ & 36.13 & 0.20 & 257.1 & -8.9 & 9.7 \\
\hline $4-6,73-75$ & 37.64 & 0.19 & 296.8 & 16.4 & 8.0 \\
\hline $5-1,70-72$ & 39.51 & 0.14 & 299.9 & 37.3 & 31.2 \\
\hline $5-2,12-14$ & 40.43 & 0.20 & 312.7 & -14.2 & 11.3 \\
\hline $5-3,78-80$ & 42.59 & 0.29 & 294.5 & 11.8 & 10.8 \\
\hline $5-4,121-123$ & 44.52 & 0.23 & 259.7 & -38.4 & 5.8 \\
\hline $5-5,108-110$ & 45.89 & 0.12 & 331.2 & -15.8 & 11.3 \\
\hline $5-6,70-72$ & 47.01 & 0.33 & 307.1 & -12.3 & 17.6 \\
\hline $5-7,47-49$ & 48.28 & 0.14 & 319.3 & -5.4 & 31.3 \\
\hline $6-1,132-134$ & 49.53 & 0.28 & 299.4 & 2.4 & 14.9 \\
\hline $6-2,58-60$ & 50.29 & 0.13 & 274.9 & 9.1 & 13.4 \\
\hline $6-3,37-39$ & 51.58 & 0.20 & 256.8 & -40.2 & 16.3 \\
\hline $7-1,39-41$ & 58.20 & 1.34 & 13.7 & -35.5 & 3.8 \\
\hline $7-2,27-29$ & 59.58 & 0.14 & 201.2 & -8.2 & 15.8 \\
\hline $8-1,19-21$ & 67.60 & 0.15 & 319.5 & -29.9 & 23.4 \\
\hline $8-2,69-71$ & 69.60 & 0.24 & 79.1 & 8.9 & 4.4 \\
\hline $9-1,53-55$ & 77.54 & 0.20 & 85.2 & -13.0 & 15.4 \\
\hline $9-2,49-51$ & 79.00 & 0.18 & 67.7 & -0.0 & 19.8 \\
\hline $10-1,87-89$ & 87.38 & 0.23 & 45.1 & 29.2 & 16.0 \\
\hline $10-2,97-99$ & 88.98 & 0.15 & 205.0 & 70.2 & 18.5 \\
\hline $10-3,10-12$ & 89.61 & 0.22 & 69.2 & 17.5 & 5.5 \\
\hline $10-4,23-25$ & 91.24 & 0.27 & 27.9 & -5.2 & 4.4 \\
\hline $11-1,136-138$ & 97.37 & 0.24 & 69.4 & -58.9 & 31.9 \\
\hline $11-2,139-141$ & 98.90 & 0.27 & 350.4 & -49.1 & 19.4 \\
\hline $11-4,48-50$ & 100.99 & 0.16 & 238.2 & -10.4 & 29.0 \\
\hline $12-1,105-107$ & 106.56 & 0.21 & 290.9 & -46.3 & 38.7 \\
\hline $12-6,118-120$ & 114.19 & 0.09 & 241.9 & 33.5 & 35.0 \\
\hline $14-1,48-50$ & 125.19 & 0.21 & 33.0 & 44.5 & 28.4 \\
\hline $15-1,109-111$ & 135.40 & 0.17 & 60.6 & -3.1 & 8.6 \\
\hline $15-4,144-146$ & 140.25 & 0.15 & 117.6 & -12.7 & 3.2 \\
\hline $16-1,111-113$ & 145.12 & 0.08 & 114.0 & 14.0 & 20.7 \\
\hline $16-3,78-80$ & 147.79 & 0.14 & 78.3 & 58.2 & 30.3 \\
\hline $17-1,103-105$ & 154.74 & 0.15 & 113.7 & 75.6 & 48.2 \\
\hline $17-2,71-73$ & 155.92 & 0.26 & 124.2 & 12.5 & 4.9 \\
\hline $17-3,78-80$ & 157.49 & 0.14 & 325.7 & 53.8 & 49.9 \\
\hline $18-1,54-56$ & 163.95 & 0.08 & 41.6 & 17.2 & 16.2 \\
\hline $19-1,52-54$ & 173.63 & 0.16 & 3.3 & 12.3 & 9.0 \\
\hline $19-2,58-60$ & 175.19 & 0.15 & 135.9 & -8.9 & 8.1 \\
\hline $19-3,97-99$ & 177.08 & 0.16 & 124.5 & -39.9 & 64.6 \\
\hline $19-4,68-70$ & 178.29 & 0.13 & 185.4 & -19.4 & 27.4 \\
\hline $19-5,89-91$ & 180.00 & 0.19 & 82.6 & -24.4 & 18.6 \\
\hline $19-6,112-114$ & 181.73 & 0.12 & 263.7 & -17.6 & 30.8 \\
\hline $20-1,66-68$ & 183.47 & 1.06 & 146.2 & -53.4 & 6.3 \\
\hline $20-2,92-94$ & 185.23 & 0.16 & 176.8 & -84.2 & 122.2 \\
\hline $20-3,127-129$ & 187.08 & 0.29 & 212.5 & -50.7 & 24.6 \\
\hline $20-4,104-106$ & 188.35 & 0.69 & 309.9 & -8.2 & 6.5 \\
\hline
\end{tabular}




\section{N. NIITSUMA}

Table 5. (Continued).

\begin{tabular}{|c|c|c|c|c|c|c|c|c|c|c|}
\hline \multirow[b]{2}{*}{$\begin{array}{c}\text { Core-Section } \\
\text { (interval in } \mathrm{cm} \text { ) }\end{array}$} & \multirow[b]{2}{*}{$\begin{array}{l}\text { Sub-bottom } \\
\text { depth (m) }\end{array}$} & \multirow[b]{2}{*}{$\begin{array}{c}\text { Intensity } \\
\left(\times 10^{-3} \mathrm{~A} / \mathrm{m}\right)\end{array}$} & \multirow[b]{2}{*}{$\begin{array}{c}\text { Relative } \\
\text { decl. } \\
\text { (degrees) }\end{array}$} & \multirow[b]{2}{*}{$\begin{array}{c}\text { Incl. } \\
\text { (degrees) }\end{array}$} & \multirow[b]{2}{*}{$\begin{array}{l}\text { Error } \\
\text { in incl. } \\
\text { (degrees) }\end{array}$} & & & & Bedding di & \\
\hline & & & & & & $\begin{array}{l}\text { Relative } \\
\text { Decl. } \\
\text { (tilt co }\end{array}$ & $\begin{array}{l}\text { Incl. } \\
\text { rr.) }\end{array}$ & & $\begin{array}{l}\text { Azimuth } \\
\text { (tilt corr.) } \\
\text { (degrees) }\end{array}$ & Dip \\
\hline Hole 584 (Cont.) & & & & & & & & & & \\
\hline $20-6,122-124$ & 191.53 & 0.69 & 339.6 & -37.4 & 9.2 & & & & & \\
\hline $21-1,11-13$ & 192.62 & 0.48 & 91.5 & -38.3 & 18.3 & 102.8 & -29.2 & 247.5 & 236.2 & 19 \\
\hline $21-2,66-68$ & 194.67 & 0.16 & 106.6 & -76.4 & 56.9 & 100.2 & -66.7 & 164.4 & 170.8 & 10 \\
\hline $21-3,101-103$ & 196.52 & 0.50 & 47.8 & -7.5 & 10.0 & & & & & \\
\hline $21-4,28-30$ & 197.29 & 0.37 & 79.0 & -25.4 & 23.9 & & & & & \\
\hline $21-5,30-32$ & 198.81 & 0.11 & 42.5 & -5.0 & 12.0 & & & & & \\
\hline $21-6,101-103$ & 201.02 & 0.12 & 141.9 & -38.7 & 48.0 & & & & & \\
\hline $22-1,29-31$ & 202.40 & 0.31 & 348.6 & -68.6 & 33.4 & & & & & \\
\hline $22-2,95-97$ & 204.56 & 0.29 & 109.6 & -32.1 & 19.6 & & & & & \\
\hline $22-3,96-98$ & 206.07 & 0.19 & 333.6 & -47.4 & 16.9 & & & & & \\
\hline $23-1,16-18$ & 211.87 & 0.41 & 273.8 & -31.5 & 28.3 & & & & & \\
\hline $23-2,7-9$ & 213.28 & 1.16 & 347.9 & -49.3 & 6.9 & & & & & \\
\hline $23-4,85-87$ & 217.06 & 0.18 & 322.3 & -67.4 & 57.9 & & & & & \\
\hline $23-5,43-45$ & 218.14 & 0.08 & 345.4 & -4.9 & 8.1 & & & & & \\
\hline $23-6,23-25$ & 219.44 & 0.35 & 109.0 & -0.9 & 10.3 & & & & & \\
\hline $24-1,7-9$ & 221.38 & 0.56 & 350.7 & -29.8 & 9.9 & & & & & \\
\hline $24-2,81-83$ & 223.62 & 0.53 & 294.3 & -16.7 & 3.3 & & & & & \\
\hline $24-3,104-106$ & 225.35 & 0.21 & 61.9 & -8.4 & 15.1 & & & & & \\
\hline $24-4,9-11$ & 225.90 & 0.72 & 165.9 & -53.6 & 10.3 & & & & & \\
\hline $24-5,48-50$ & 227.79 & 0.56 & 33.8 & -36.9 & 20.4 & & & & & \\
\hline $25-2,2-4$ & 230.83 & 0.29 & 266.1 & -70.6 & 20.9 & & & & & \\
\hline $26-1,16-18$ & 240.47 & 0.46 & 197.2 & -11.0 & 3.8 & & & & & \\
\hline $26-2,107-109$ & 242.88 & 0.39 & 10.7 & -18.4 & 5.4 & & & & & \\
\hline $26-4,93-95$ & 245.74 & 0.30 & 128.8 & -34.9 & 22.2 & & & & & \\
\hline $26-5,39-41$ & 246.70 & 0.30 & 19.9 & -12.9 & 5.2 & & & & & \\
\hline $27-1,132-134$ & 251.13 & 0.29 & 87.4 & -24.0 & 28.0 & 91.1 & -34.0 & 327.6 & 323.9 & 12 \\
\hline $27-2,125-127$ & 252.56 & 0.44 & 16.7 & -30.5 & 4.9 & 24.5 & -31.0 & 276.3 & 268.5 & 13 \\
\hline $27-3,72-74$ & 253.53 & 0.74 & 355.5 & -24.5 & 8.5 & 357.8 & -24.9 & 275.5 & 273.2 & 5 \\
\hline $27-4,4-6$ & 254.35 & 0.40 & 3.1 & -40.6 & 11.5 & 27.6 & -56.3 & 317.9 & 293.4 & 26 \\
\hline $27-5,48-50$ & 256.29 & 0.24 & 357.8 & -1.4 & 33.8 & 358.3 & -11.5 & 336.2 & 335.7 & 11 \\
\hline $27-6,25-27$ & 257.56 & 0.52 & 347.0 & -76.3 & 20.4 & 337.4 & -68.8 & 153.0 & 162.6 & 8 \\
\hline $28-1,50-52$ & 259.81 & 0.73 & 350.5 & -35.5 & 6.5 & & & & & \\
\hline $28-3,3-5$ & 262.34 & 0.31 & 323.5 & -56.3 & 35.9 & & & & & \\
\hline $29-1,9-11$ & 268.90 & 0.18 & 165.9 & -27.6 & 20.2 & & & & & \\
\hline $29-2,87-89$ & 271.18 & 0.40 & 346.0 & -30.0 & 27.9 & & & & & \\
\hline $29-4,108-110$ & 274.39 & 0.25 & 354.5 & -3.5 & 3.0 & & & & & \\
\hline $29-6,35-37$ & 276.66 & 0.33 & 66.4 & -58.3 & 14.2 & & & & & \\
\hline $30-1,67-69$ & 278.98 & 0.29 & 217.5 & 59.7 & 21.3 & & & & & \\
\hline $30-2,88-90$ & 280.69 & 0.30 & 323.8 & 9.8 & 27.6 & & & & & \\
\hline $32-1,27-29$ & 297.58 & 0.52 & 256.6 & 52.9 & 6.2 & 272.7 & 68.7 & 158.4 & 142.3 & 18 \\
\hline $32-2,91-93$ & 299.72 & 0.28 & 357.9 & 48.9 & 28.0 & & & & & \\
\hline $34-1,53-55$ & 316.94 & 0.19 & 1.0 & 69.2 & 26.9 & 297.9 & 77.8 & 216.0 & 279.1 & 19 \\
\hline $34-2,87-89$ & 318.78 & 0.10 & 62.1 & -59.5 & 72.8 & 72.3 & -46.5 & 215.9 & 205.7 & 15 \\
\hline $34-3,54-56$ & 319.95 & 0.25 & 5.2 & 43.8 & 18.5 & 355.6 & 43.7 & 265.8 & 275.4 & 10 \\
\hline $34-5,54-56$ & 322.95 & 0.06 & 145.3 & -22.1 & 59.9 & 149.1 & -27.7 & 305.7 & 301.9 & 10 \\
\hline $34-6,71-73$ & 324.62 & 0.12 & 149.6 & 66.5 & 38.9 & 121.0 & 59.3 & 281.4 & 310.0 & 16 \\
\hline $35-1,95-97$ & 326.96 & 0.72 & 169.2 & 74.4 & 15.3 & & & & & \\
\hline $35-2,100-102$ & 328.51 & 0.63 & 2.1 & 65.7 & 27.2 & & & & & \\
\hline $35-3,62-64$ & 329.63 & 0.22 & 72.0 & 76.3 & 47.9 & & & & & \\
\hline $36-1,53-55$ & 336.14 & 0.33 & 330.1 & -0.1 & 3.4 & 318.1 & -35.5 & 39.9 & 51.9 & 49 \\
\hline $36-4,86-88$ & 340.97 & 0.26 & 350.6 & -24.0 & 29.4 & 359.1 & -40.5 & 325.4 & 317.0 & 21 \\
\hline $37-1,52-54$ & 345.63 & 0.35 & 316.1 & -89.0 & 6.2 & & & & & \\
\hline $37-4,120-122$ & 350.81 & 0.31 & 339.3 & 27.1 & 11.5 & & & & & \\
\hline $37-5,98-100$ & 352.09 & 0.65 & 4.3 & 41.1 & 5.0 & 23.4 & 58.0 & 145.7 & 126.6 & 23 \\
\hline $37-6,27-29$ & 352.88 & 0.45 & 171.1 & 44.3 & 9.3 & 182.1 & 54.9 & 143.9 & 132.9 & 14 \\
\hline $38-1,5-7$ & 354.66 & 0.64 & 32.6 & 53.2 & 7.9 & 58.4 & 57.0 & 114.4 & 88.6 & 18 \\
\hline $38-4,41-43$ & 359.52 & 0.36 & 48.0 & -33.2 & 11.0 & 52.9 & -50.4 & 345.0 & 340.1 & 18 \\
\hline $39-1,67-69$ & 364.78 & 0.63 & 63.8 & 54.1 & 4.5 & & & & & \\
\hline $39-2,27-29$ & 365.88 & 0.53 & 163.3 & 58.3 & 8.0 & 154.0 & 38.8 & 332.7 & 342.0 & 21 \\
\hline $40-1,23-25$ & 373.94 & 0.36 & 282.1 & 2.6 & 11.0 & 281.9 & -3.3 & 78.9 & 79.1 & 30 \\
\hline $40-4,20-22$ & 378.41 & 0.38 & 129.1 & -37.8 & 2.4 & 138.1 & -24.2 & 231.9 & 222.9 & 20 \\
\hline $42-1,12-14$ & 393.03 & 0.68 & 287.9 & -18.3 & 2.3 & 303.7 & -45.4 & 325.1 & 309.3 & 36 \\
\hline $42-2,17-19$ & 394.58 & 0.32 & 316.6 & -17.7 & 14.2 & 323.9 & -5.5 & 254.4 & 247.1 & 36 \\
\hline $42-5,111-113$ & 400.02 & 0.39 & 103.3 & -10.7 & 6.5 & 101.4 & -42.5 & 5.7 & 7.6 & 32 \\
\hline $43-1,48-50$ & 403.09 & 0.08 & 109.5 & -11.1 & 37.1 & 100.9 & -27.7 & 51.5 & 60.1 & 29 \\
\hline $43-2,29-31$ & 404.40 & 0.41 & 286.2 & -47.1 & 11.1 & 299.3 & -24.0 & 224.8 & 211.7 & 29 \\
\hline $44-1,34-36$ & 412.65 & 0.26 & 49.9 & -28.7 & 13.4 & 34.4 & -36.7 & 64.1 & 79.6 & 25 \\
\hline $44-4,48-50$ & 417.29 & 0.16 & 99.1 & -35.9 & 12.7 & 108.5 & -44.6 & 312.9 & 303.5 & 14 \\
\hline $46-1,57-59$ & 432.08 & 0.51 & 265.7 & 37.8 & 7.4 & 277.6 & 22.6 & 59.3 & 47.4 & 25 \\
\hline $47-1,5-7$ & 441.06 & 0.29 & 192.3 & 51.1 & 4.9 & 230.1 & 51.6 & 109.7 & 71.9 & 29 \\
\hline $47-2,129-131$ & 443.80 & 0.95 & 16.5 & 42.6 & 2.3 & 52.4 & 59.5 & 137.5 & 101.6 & 32 \\
\hline $48-1,55-57$ & 451.06 & 0.92 & 95.5 & 50.3 & 5.0 & & & & & \\
\hline $48-2,24-26$ & 452.25 & 0.57 & 309.1 & 61.4 & 15.8 & 335.6 & 28.9 & 51.9 & 25.4 & 40 \\
\hline
\end{tabular}


Table 5. (Continued).

\begin{tabular}{|c|c|c|c|c|c|c|c|c|c|c|}
\hline \multirow[b]{2}{*}{$\begin{array}{c}\text { Core-Section } \\
\text { (interval in cm) }\end{array}$} & \multirow[b]{2}{*}{$\begin{array}{l}\text { Sub-bottom } \\
\text { depth (m) }\end{array}$} & \multirow[b]{2}{*}{$\begin{array}{c}\text { Intensity } \\
\left(\times 10^{-3} \mathrm{~A} / \mathrm{m}\right)\end{array}$} & \multirow[b]{2}{*}{$\begin{array}{c}\text { Relative } \\
\text { decl. } \\
\text { (degrees) }\end{array}$} & \multirow[b]{2}{*}{$\begin{array}{c}\text { Incl. } \\
\text { (degrees) }\end{array}$} & \multirow[b]{2}{*}{$\begin{array}{l}\text { Error } \\
\text { in incl. } \\
\text { (degrees) }\end{array}$} & & & & Bedding di & \\
\hline & & & & & & $\begin{array}{l}\text { Relative } \\
\text { Decl. } \\
\text { (tilt }\end{array}$ & $\begin{array}{l}\text { Incl. } \\
\text { rr.) }\end{array}$ & & $\begin{array}{l}\text { Azimuth } \\
\text { (tilt corr.) } \\
\quad \text { (degrees) }\end{array}$ & Dip \\
\hline Hole 584 (Cont.) & & & & & & & & & & \\
\hline $48-3,40-42$ & 453.91 & 0.59 & 214.4 & 71.7 & 7.8 & 268.5 & 65.4 & 101.6 & 47.5 & 21 \\
\hline $49-1,84-86$ & 460.95 & 0.59 & 196.9 & 82.9 & 17.4 & 287.2 & 62.1 & 105.1 & 14.8 & 29 \\
\hline $50-1,62-64$ & 470.33 & 0.59 & 207.6 & 53.8 & 8.6 & 245.3 & 57.8 & 117.4 & 79.7 & 25 \\
\hline $51-1,61-63$ & 479.92 & 0.24 & 137.3 & 17.3 & 25.2 & 147.3 & 20.2 & 100.7 & 90.7 & 29 \\
\hline $52-1,40-42$ & 489.31 & 0.42 & 334.9 & 22.1 & 24.2 & 3.0 & 62.4 & 157.1 & 129.0 & 48 \\
\hline $52-3,86-88$ & 492.77 & 1.25 & 26.9 & 67.8 & 10.4 & 265.2 & 76.1 & 202.1 & 323.8 & 32 \\
\hline $53-1,38-40$ & 498.89 & 0.35 & 107.9 & -20.1 & 4.3 & 117.6 & -18.8 & 272.1 & 262.4 & 27 \\
\hline $53-2,65-67$ & 500.66 & 0.20 & 348.0 & 14.8 & 25.7 & 348.1 & -15.7 & 330.0 & 329.9 & 35 \\
\hline $53-3,50-52$ & 502.01 & 0.15 & 338.8 & -22.3 & 6.8 & 340.6 & -55.2 & 357.2 & 355.4 & 33 \\
\hline $54-1,50-52$ & 508.61 & 0.69 & 339.7 & 8.8 & 4.0 & 339.0 & -10.4 & 67.3 & 68.0 & 48 \\
\hline $54-2,62-64$ & 510.23 & 0.22 & 39.6 & -20.1 & 28.2 & 30.9 & -14.3 & 97.4 & 106.1 & 28 \\
\hline $54-3,52-54$ & 511.63 & 0.32 & 96.2 & -0.1 & 7.8 & 87.1 & -28.4 & 43.8 & 51.9 & 41 \\
\hline $54-4,119-121$ & 513.80 & 0.31 & 297.3 & 72.9 & 37.8 & 249.5 & 43.8 & 289.7 & 337.5 & 38 \\
\hline $54-5,81-83$ & 514.92 & 0.29 & 30.0 & 10.4 & 3.8 & 21.7 & 21.8 & 244.1 & 252.3 & 30 \\
\hline $54-6,72-74$ & 516.33 & 0.20 & 91.7 & 1.3 & 8.9 & 89.0 & -23.4 & 27.3 & 30.0 & 28 \\
\hline $55-1,21-23$ & 517.82 & 0.38 & 12.8 & -31.4 & 13.5 & 35.7 & -52.6 & 321.2 & 298.3 & 32 \\
\hline $55-2,79-81$ & 519.90 & 0.69 & 257.9 & 71.0 & 16.4 & 283.1 & 45.6 & 44.1 & 18.9 & 29 \\
\hline $55-3,94-96$ & 521.55 & 0.28 & 248.9 & 57.1 & 33.9 & 295.2 & 45.9 & 97.1 & 50.8 & 36 \\
\hline $55-4,79-81$ & 522.90 & 0.18 & 94.8 & 44.5 & 16.1 & 122.2 & 39.3 & 94.2 & 66.8 & 30 \\
\hline $55-5,83-85$ & 524.44 & 0.58 & 236.5 & 54.2 & 23.2 & 265.5 & 32.4 & 69.5 & 40.5 & 36 \\
\hline $56-1,118-120$ & 528.29 & 0.34 & 20.1 & 39.0 & 7.6 & 48.4 & 32.5 & 94.9 & 66.6 & 38 \\
\hline $56-2,77-79$ & 529.38 & 0.37 & 195.8 & 67.9 & 28.5 & 253.4 & 44.1 & 89.2 & 31.6 & 41 \\
\hline $56-3,24-26$ & 530.35 & 2.96 & 305.4 & 62.9 & 2.5 & 334.6 & 15.9 & 50.6 & 21.4 & 35 \\
\hline $56-4,34-36$ & 531.95 & 0.11 & 259.0 & 17.5 & 42.8 & 258.6 & -20.5 & 19.0 & 19.4 & 40 \\
\hline $57-1,121-123$ & 537.82 & 0.15 & 54.9 & -67.3 & 68.2 & 352.1 & -45.4 & 84.1 & 146.9 & 42 \\
\hline $57-2,129-131$ & 539.40 & 0.10 & 256.8 & -34.6 & 23.9 & 238.9 & -60.4 & 23.2 & 41.1 & 30 \\
\hline $57-3,108-110$ & 540.69 & 0.41 & 35.2 & 10.6 & 14.8 & 35.3 & -11.1 & 315.8 & 315.7 & 30 \\
\hline $58-1,125-127$ & 547.36 & 0.06 & 139.1 & -18.3 & 16.7 & 159.0 & -44.5 & 318.9 & 299.0 & 40 \\
\hline $58-2,55-57$ & 548.16 & 0.31 & 24.0 & 53.1 & 11.8 & 56.4 & 41.1 & 85.0 & 52.6 & 31 \\
\hline $59-1,117-119$ & 556.78 & 0.23 & 31.1 & -7.9 & 27.2 & 18.2 & -48.7 & 22.9 & 35.8 & 46 \\
\hline $59-2,38-40$ & 557.49 & 0.33 & 306.0 & 82.4 & 42.0 & 112.1 & 59.5 & 169.0 & 2.9 & 38 \\
\hline $60-1,44-46$ & 566.00 & 1.62 & 190.4 & -45.8 & 6.0 & 226.6 & -25.4 & 266.6 & 230.4 & 50 \\
\hline $61-2,71-73$ & 576.82 & 0.19 & 111.8 & 16.1 & 8.2 & 121.2 & 14.7 & 92.2 & 82.8 & 33 \\
\hline $62-1,36-38$ & 584.47 & 0.24 & 61.8 & 6.4 & 0.5 & 61.9 & -6.3 & 71.2 & 71.1 & 38 \\
\hline $62-2,120-122$ & 586.81 & 0.35 & 66.8 & 34.0 & 23.4 & 83.5 & 10.2 & 68.2 & 51.5 & 45 \\
\hline $62-3,83-85$ & 587.94 & 1.70 & 147.6 & 46.4 & 1.1 & 185.0 & 32.8 & 92.4 & 55.0 & 44 \\
\hline $62-4,92-94$ & 589.53 & 1.26 & 164.6 & 77.3 & 6.5 & 246.3 & 40.7 & 98.4 & 16.7 & 50 \\
\hline $62-5,96-98$ & 591.07 & 0.73 & 1.0 & 54.3 & 9.8 & 17.6 & 18.6 & 40.0 & 23.4 & 41 \\
\hline $63-1,91-93$ & 594.52 & 0.51 & 188.0 & 56.3 & 23.6 & 222.8 & 32.6 & 74.0 & 39.2 & 40 \\
\hline $63-2,128-130$ & 596.39 & 0.69 & 313.8 & 54.1 & 14.5 & 297.8 & 9.2 & 323.2 & 339.2 & 50 \\
\hline $64-1,92-94$ & 604.13 & 0.65 & 75.5 & 74.6 & 19.0 & 240.5 & 52.1 & 169.5 & 4.5 & 53 \\
\hline $65-1,102-104$ & 613.83 & 90.02 & 143.6 & -29.6 & 1.1 & 182.6 & -85.4 & 356.4 & 317.4 & 57 \\
\hline $65-2,73-75$ & 615.04 & 5.25 & 180.6 & -14.9 & 1.5 & 200.6 & -29.4 & 296.4 & 276.4 & 48 \\
\hline $66-1,35-37$ & 622.76 & 60.21 & 176.4 & -18.8 & 0.6 & 210.9 & -43.7 & 310.6 & 276.1 & 56 \\
\hline $66-1,136-138$ & 623.77 & 3.71 & 108.9 & 6.0 & 0.7 & 116.4 & -20.8 & 299.1 & 291.6 & 58 \\
\hline $67-1,72-74$ & 632.83 & 8.36 & 54.0 & 26.2 & 1.3 & 108.7 & 51.8 & 137.0 & 82.3 & 62 \\
\hline $68-1,87-89$ & 642.68 & 0.54 & 73.0 & 8.2 & 9.5 & 70.2 & -29.2 & 20.0 & 22.8 & 40 \\
\hline $68-2,15-17$ & 643.46 & 5.01 & 23.3 & 18.2 & 2.3 & 19.8 & -10.9 & 296.7 & 300.2 & 57 \\
\hline $70-1,107-109$ & 662.28 & 0.60 & 223.7 & 11.4 & 3.0 & 230.1 & 5.4 & 85.3 & 78.9 & 42 \\
\hline $70-2,87-89$ & 663.58 & 3.03 & 71.3 & 29.8 & 0.7 & 107.6 & 38.2 & 116.7 & 80.4 & 50 \\
\hline $71-1,100-102$ & 671.91 & 0.30 & 126.4 & 17.6 & 22.8 & 155.2 & 49.4 & 140.6 & 111.8 & 50 \\
\hline $72-1,26-28$ & 680.87 & 0.80 & 350.5 & 51.8 & 15.1 & 17.3 & 33.6 & 71.5 & 44.7 & 33 \\
\hline $73-1,76-78$ & 690.97 & 0.40 & 291.1 & 45.0 & 31.7 & 299.5 & 7.1 & 27.9 & 19.5 & 41 \\
\hline $73-2,145-147$ & 693.16 & 0.30 & 34.5 & 45.0 & 18.0 & 24.4 & 4.5 & 327.5 & 337.6 & 45 \\
\hline $74-1,98-100$ & 700.79 & 0.28 & 240.8 & 55.9 & 27.3 & 294.0 & 24.3 & 91.2 & 38.0 & 61 \\
\hline $75-1,37-39$ & 709.78 & 0.70 & 220.9 & 55.6 & 13.6 & 254.7 & 29.8 & 72.1 & 38.3 & 42 \\
\hline $75-2,56-58$ & 711.47 & 0.63 & 150.5 & 55.9 & 2.2 & 212.8 & 20.4 & 98.5 & 36.2 & 71 \\
\hline $76-1,111-113$ & 720.22 & 1.31 & 221.9 & 75.5 & 6.5 & 304.2 & 24.3 & 98.1 & 15.8 & 67 \\
\hline $76-2,102-104$ & 721.63 & 0.83 & 32.0 & 41.4 & 7.0 & 161.8 & 79.7 & 171.0 & 41.2 & 56 \\
\hline $77-1,92-94$ & 729.73 & 0.78 & 72.4 & 51.6 & 7.0 & 129.6 & 52.5 & 119.6 & 62.4 & 41 \\
\hline $77-2,72-74$ & 731.03 & 0.55 & 19.5 & 56.6 & 21.8 & 70.6 & 50.1 & 106.5 & 55.4 & 36 \\
\hline $78-1,138-140$ & 739.89 & 0.48 & 176.1 & 83.5 & 29.6 & & & & & \\
\hline $78-3,50-52$ & 742.01 & 0.50 & 278.2 & 33.9 & 16.6 & 339.7 & 47.8 & 130.8 & 69.3 & 62 \\
\hline $79-1,128-130$ & 749.29 & 0.54 & 34.3 & 47.0 & 4.0 & 140.9 & 45.5 & 142.7 & 36.1 & 75 \\
\hline $80-2,80-82$ & 759.81 & 0.48 & 133.8 & 80.7 & 20.6 & 261.9 & 21.5 & 135.2 & 7.1 & 75 \\
\hline $80-3,49-51$ & 761.00 & 0.29 & 138.0 & 43.4 & 32.3 & 193.4 & 39.0 & 114.0 & 58.6 & 56 \\
\hline $81-2,16-18$ & 768.67 & 0.29 & 196.6 & 59.3 & 27.9 & 157.5 & 19.5 & 290.4 & 329.5 & 56 \\
\hline $81-3,136-138$ & 771.37 & 0.61 & 121.4 & 79.8 & 12.9 & 150.4 & 25.5 & 35.6 & 6.6 & 56 \\
\hline $83-1,126-128$ & 787.67 & 0.43 & 103.2 & 71.5 & 9.0 & 100.7 & 36.6 & 355.8 & 358.3 & $\begin{array}{r}35 \\
61\end{array}$ \\
\hline $83-3,44-46$ & 789.85 & 0.29 & 59.4 & 74.4 & 17.4 & 264.8 & 48.6 & 198.6 & 353.2 & 61 \\
\hline $83-4,129-131$ & 792.20 & 0.29 & 322.8 & 38.0 & 34.2 & 300.7 & 37.3 & 260.2 & 282.3 & 28 \\
\hline $85-1,104-106$ & 806.85 & 0.24 & 21.9 & 55.6 & 29.1 & 304.6 & 39.9 & 242.1 & 319.4 & 60 \\
\hline $85-1,104-106$ & 808.35 & 0.29 & 61.9 & 31.6 & 19.2 & 66.6 & -8.3 & 31.1 & 26.4 & 45 \\
\hline
\end{tabular}


Table 5. (Continued).

\begin{tabular}{|c|c|c|c|c|c|c|c|c|c|c|}
\hline \multirow[b]{2}{*}{$\begin{array}{c}\text { Core-Section } \\
\text { (interval in cm) }\end{array}$} & \multirow[b]{2}{*}{$\begin{array}{l}\text { Sub-bottom } \\
\text { depth }(m)\end{array}$} & \multirow[b]{2}{*}{$\begin{array}{c}\text { Intensity } \\
\left(\times 10^{-3} \mathrm{~A} / \mathrm{m}\right)\end{array}$} & \multirow[b]{2}{*}{$\begin{array}{c}\text { Relative } \\
\text { decl. } \\
\text { (degrees) }\end{array}$} & \multirow[b]{2}{*}{$\begin{array}{c}\text { Incl. } \\
\text { (degrees) }\end{array}$} & \multirow[b]{2}{*}{$\begin{array}{l}\text { Error } \\
\text { in incl. } \\
\text { (degrees) }\end{array}$} & \multirow{2}{*}{\multicolumn{2}{|c|}{$\begin{array}{l}\text { Relative } \\
\text { Decl. Incl. } \\
\text { (tilt corr.) }\end{array}$}} & & \multicolumn{2}{|c|}{ Bedding dip } \\
\hline & & & & & & & & & $\begin{array}{l}\text { Azimuth } \\
\text { (tilt corr.) } \\
\quad \text { (degrees) }\end{array}$ & Dip \\
\hline \multicolumn{11}{|l|}{ Hole 584 (Cont.) } \\
\hline $85-2,87-89$ & 816.38 & 0.47 & 257.0 & 63.3 & 24.8 & 341.7 & 60.0 & 129.0 & 44.3 & 40 \\
\hline $86-2,76-78$ & 817.77 & 0.46 & 231.3 & 70.4 & 30.1 & 282.4 & 36.2 & 74.7 & 23.6 & 46 \\
\hline $87-1,66-68$ & 826.17 & 0.34 & 100.1 & 57.7 & 10.1 & 256.5 & 76.5 & 172.9 & 16.5 & 45 \\
\hline $87-2,23-25$ & 827.24 & 0.47 & 15.0 & 37.6 & 9.3 & 38.2 & 18.4 & 78.0 & 54.8 & 45 \\
\hline $87-3,64-66$ & 829.15 & 0.62 & 237.7 & 64.0 & 12.5 & 315.5 & 37.6 & 109.3 & 31.5 & 57 \\
\hline $88-2,132-134$ & 837.63 & 0.20 & 286.7 & 37.3 & 18.7 & 304.3 & 6.7 & 63.3 & 45.7 & 50 \\
\hline $88-4,101-103$ & 840.32 & 0.26 & 257.7 & 22.2 & 6.7 & 258.0 & -21.1 & 37.3 & 37.0 & 53 \\
\hline $88-6,3-5$ & 841.34 & 0.19 & 79.0 & 28.6 & 23.7 & 90.3 & -7.3 & 64.0 & 52.7 & 63 \\
\hline $89-1,78-80$ & 845.19 & 0.35 & 13.9 & 64.8 & 25.0 & 81.9 & 51.1 & 108.1 & 40.1 & 40 \\
\hline $89-2,95-97$ & 846.86 & 0.13 & 4.7 & 52.4 & 43.4 & 86.4 & 47.2 & 127.3 & 45.6 & 58 \\
\hline $90-1,140-142$ & 855.41 & 0.44 & 35.4 & 40.8 & 22.1 & 70.1 & 70.5 & 158.6 & 123.9 & 36 \\
\hline $90-2,27-29$ & 855.78 & 0.07 & 251.9 & 23.6 & 30.2 & 252.4 & 54.6 & 179.1 & 178.6 & 31 \\
\hline $90-3,80-82$ & 857.81 & 0.63 & 274.8 & -68.2 & 11.8 & 289.1 & -40.6 & 207.2 & 192.9 & 29 \\
\hline $91-1,50-52$ & 864.21 & 0.78 & 13.1 & 5.5 & 14.6 & & & & & \\
\hline $91-1,86-88$ & 864.57 & 1.08 & 315.5 & 15.1 & 3.8 & 317.5 & -33.7 & 347.5 & 345.5 & 50 \\
\hline $92-1,56-58$ & 873.97 & 0.63 & 174.0 & 44.9 & 12.1 & 268.7 & 50.1 & 140.0 & 45.3 & 68 \\
\hline $92-2,14-16$ & 884.75 & 0.67 & 266.0 & 24.8 & 6.8 & & & & & \\
\hline $93-3,58-60$ & 886.69 & 0.84 & 30.8 & 57.4 & 2.1 & 117.3 & 67.3 & 143.2 & 56.7 & 40 \\
\hline $94-1,113-115$ & 893.94 & 0.51 & 276.1 & 68.0 & 12.7 & 225.1 & 33.9 & 282.9 & 333.9 & 48 \\
\hline $95-1,120-122$ & 903.71 & 1.55 & 352.3 & 52.4 & 6.8 & 33.1 & 44.6 & 98.7 & 57.9 & 35 \\
\hline $95-2,103-105$ & 905.04 & 0.83 & 144.9 & 66.6 & 11.9 & 192.2 & 32.2 & 74.1 & 26.8 & 48 \\
\hline $95-3,24-26$ & 905.75 & 0.33 & 171.5 & 86.7 & 22.4 & 265.3 & 55.4 & 99.5 & 5.7 & 35 \\
\hline $96-1,74-76$ & 912.95 & 0.87 & 31.9 & 63.0 & 13.2 & 84.3 & 39.1 & 88.1 & 35.7 & 44 \\
\hline $96-2,88-90$ & 914.59 & 0.84 & 12.9 & 48.7 & 5.8 & 37.8 & 17.9 & 63.1 & 38.2 & 46 \\
\hline $96-4,17-19$ & 915.38 & 0.45 & 309.3 & 51.5 & 9.4 & 320.3 & 10.6 & 28.7 & 17.7 & 44 \\
\hline $96-4,144-146$ & 916.65 & 0.81 & 271.3 & 52.2 & 8.8 & 300.1 & 23.5 & 66.7 & 37.9 & 44 \\
\hline $97-1,51-53$ & 922.32 & 0.64 & 343.6 & 59.7 & 8.3 & 38.7 & 52.6 & 107.4 & 52.3 & 35 \\
\hline \multicolumn{11}{|l|}{ Hole $584 \mathrm{~A}$} \\
\hline H1-6, 136-138 & 8.87 & 0.61 & 36.8 & 56.2 & 15.6 & & & & & \\
\hline $1-1,40-42$ & 602.61 & 4.03 & 338.7 & -24.7 & 2.3 & 16.9 & -56.5 & 324.3 & 286.1 & 50 \\
\hline $1-2,26-28$ & 603.97 & 47.79 & 44.2 & -55.7 & 2.1 & 63.8 & -53.4 & 270.8 & 251.2 & 14 \\
\hline $\mathrm{H} 2-1,53-55$ & 612.34 & 8.85 & 309.9 & -25.0 & 1.3 & 324.0 & -67.5 & 350.1 & 336.0 & 44 \\
\hline $\mathrm{H} 2-2,39-41$ & 613.70 & 10.86 & 124.4 & -15.6 & 1.0 & 150.7 & -38.2 & 306.6 & 280.3 & 52 \\
\hline H2-4, 9-11 & 616.40 & 3.96 & 38.8 & 1.9 & 0.6 & 52.7 & -36.2 & 318.2 & 304.3 & 55 \\
\hline $2-2,27-29$ & 700.58 & 0.48 & 193.7 & 57.6 & 27.9 & 216.9 & 27.3 & 51.3 & 28.1 & 38 \\
\hline $2-2,132-134$ & 701.63 & 1.40 & 336.9 & 43.3 & 3.8 & 23.4 & 44.0 & 114.1 & 67.6 & 45 \\
\hline H3-2, 116-118 & 711.07 & 0.55 & 120.3 & 49.5 & 10.6 & 109.7 & 7.9 & 330.7 & 341.3 & 45 \\
\hline $3-1,52-54$ & 795.63 & 0.26 & 316.9 & 44.8 & 22.1 & 347.4 & 8.5 & 74.1 & 43.6 & 63 \\
\hline $3-2,99-101$ & 797.60 & 0.27 & 331.2 & 73.0 & 11.1 & 342.8 & 21.6 & 16.8 & 5.2 & 52 \\
\hline H4-1, 104-106 & 805.85 & 0.28 & 233.7 & 54.5 & 12.8 & 278.6 & 35.3 & 90.3 & 45.4 & 45 \\
\hline $\mathrm{H} 4-2,105-107$ & 807.36 & 0.31 & 98.6 & 40.9 & 12.5 & 100.2 & 0.1 & 6.4 & 4.8 & 41 \\
\hline \multicolumn{11}{|l|}{ Hole 584B } \\
\hline $\mathrm{H} 2-1,40-42$ & 510.11 & 0.93 & 55.3 & 78.0 & 10.8 & 296.1 & 73.3 & 215.7 & 334.9 & 25 \\
\hline $\mathrm{H} 2-2,120-122$ & 512.41 & 0.19 & 49.6 & 50.6 & 33.0 & 62.8 & 40.9 & 59.4 & 46.2 & 16 \\
\hline $2-5,2-4$ & 650.13 & 2.40 & 173.7 & 42.5 & 3.9 & 210.3 & 32.9 & 97.3 & 60.7 & 45 \\
\hline H3-2, 91-93 & 656.22 & 0.18 & 40.3 & 16.9 & 14.2 & 39.4 & -19.2 & 50.7 & 51.6 & 55 \\
\hline H3-2, 139-141 & 656.70 & 0.20 & 44.4 & 43.7 & 31.1 & 59.3 & -0.6 & 46.6 & 31.7 & 55 \\
\hline $\mathrm{H} 3-3,61-63$ & 657.42 & 0.27 & 315.6 & 17.0 & 15.4 & 332.7 & 10.8 & 93.4 & 76.3 & 62 \\
\hline $\mathrm{H} 4-1,32-34$ & 847.13 & 0.38 & 348.1 & 51.2 & 9.1 & 128.7 & 49.4 & 159.9 & 19.3 & 76 \\
\hline
\end{tabular}

Note decl. $=$ declination; incl. $=$ inclination; corr. $=$ correction .

the positive inclination of normally magnetized samples is much less affected by the overprint (Fig. 24). This relation indicates that shallow positive inclinations, which were measured frequently at this site (Fig. 21), might be derived from negative inclinations of reversed polarity by the overprint.

Stereographic projections of bedding-plane dips of all samples from Hole 584 show the general eastward tilt (Fig. 25). The line $I=0$ in Figure 25B represents zero inclination after bedding correction. Because the line crosses the area of the distribution of the poles, represented by open circles and solid rhomb-samples with negative and less than $+35^{\circ}$ inclinations, respectivelywe can conclude that most were remagnetized. With this assumption, we can determine the original polarity of the sample not only by the magnetic inclination but also by the direction of bedding tilt.

The magnetostratigraphy shown in Figures 17 and 26 is based on the estimated geomagnetic polarity of the measured samples, and correlation with standard magnetostratigraphic scale is supplemented by the diatom biostratigraphic data (Akiba, this volume). As calculated from the relation between magnetobiostratigraphy and age, the accumulation rate changed drastically (Fig. 26). 


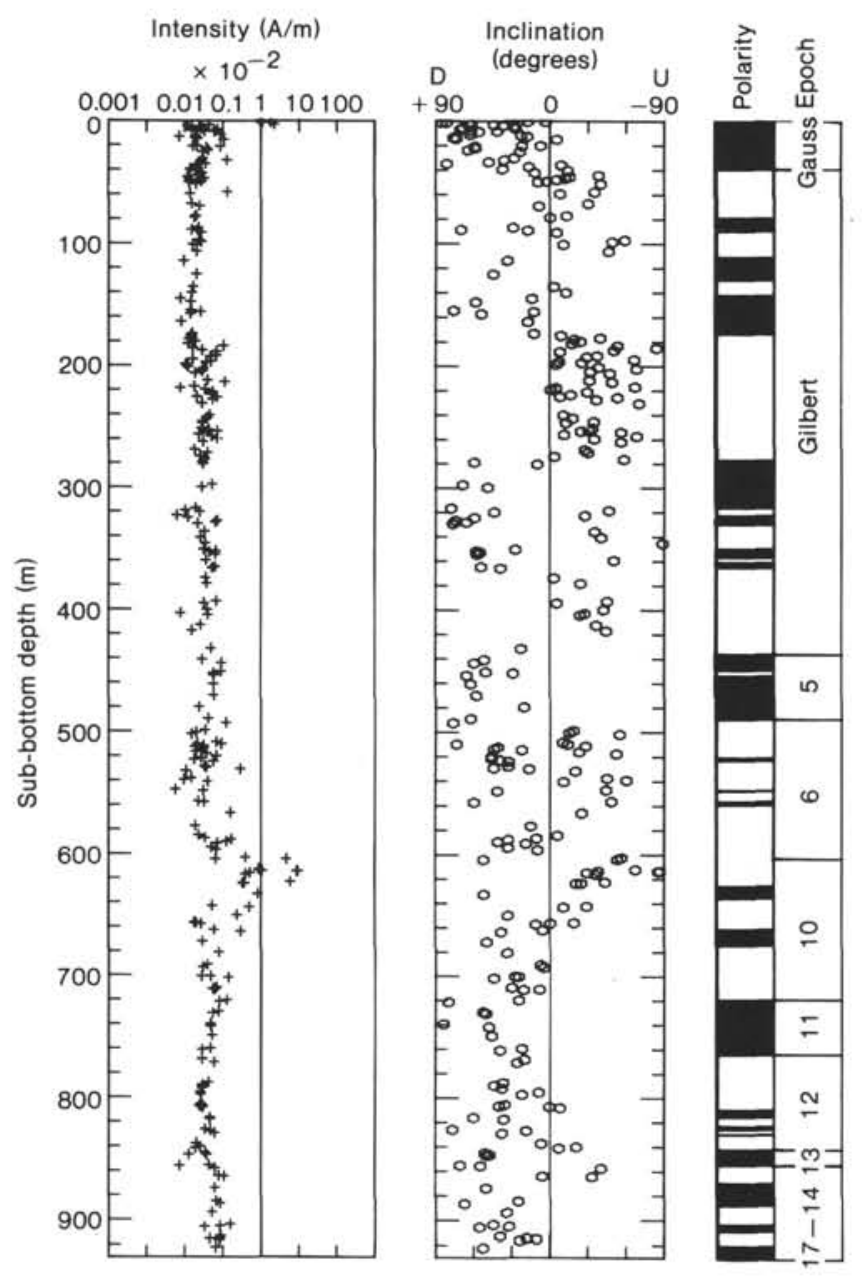

Figure 17. Magnetostratigraphy of Hole 584. Measurements by a ringcore-type fluxgate spinner magnetometer after 15-mT AF demagnetization.

Extremely low rates, less than $20 \mathrm{~m} / \mathrm{Ma}$ near $600 \mathrm{~m}$ subbottom depth, are accompanied by hiatuses. The relation between the accumulation rate and tectonism in the Japanese island arc is discussed in more detail in a companion chapter (Niitsuma and Akiba, this volume).

In intervals labeled A-H (Fig. 26), bedding tilts northward and westward, significantly different from the general eastward dip. Interval $\mathrm{A}$ is just above a zone with recovery of brecciated sediments. Below interval $\mathrm{B}$, the dip of bedding increases with depth from 25 to $50^{\circ}$. No increase in the dip angle occurs below intervals E-F, and the dip angle is $50^{\circ}$ on the average, with fluctuations of $20^{\circ}$. These intervals are also remarkable for their low accumulation rate and number of hiatuses. Possible causes of this relation among the tilt direction, dip angles, and unconformities are (1) faulting; (2) clino-unconformity; and (3) differential deformation. The first and second causes can be eliminated, because changes in dip angle correspond to changes in accumulation rate, biostratigraphic sequences are not repeated, and dip angles increase with sub-bottom depth. The third cause is the most likely to explain these relations. Differential deformation can be derived from the differences in lithologic

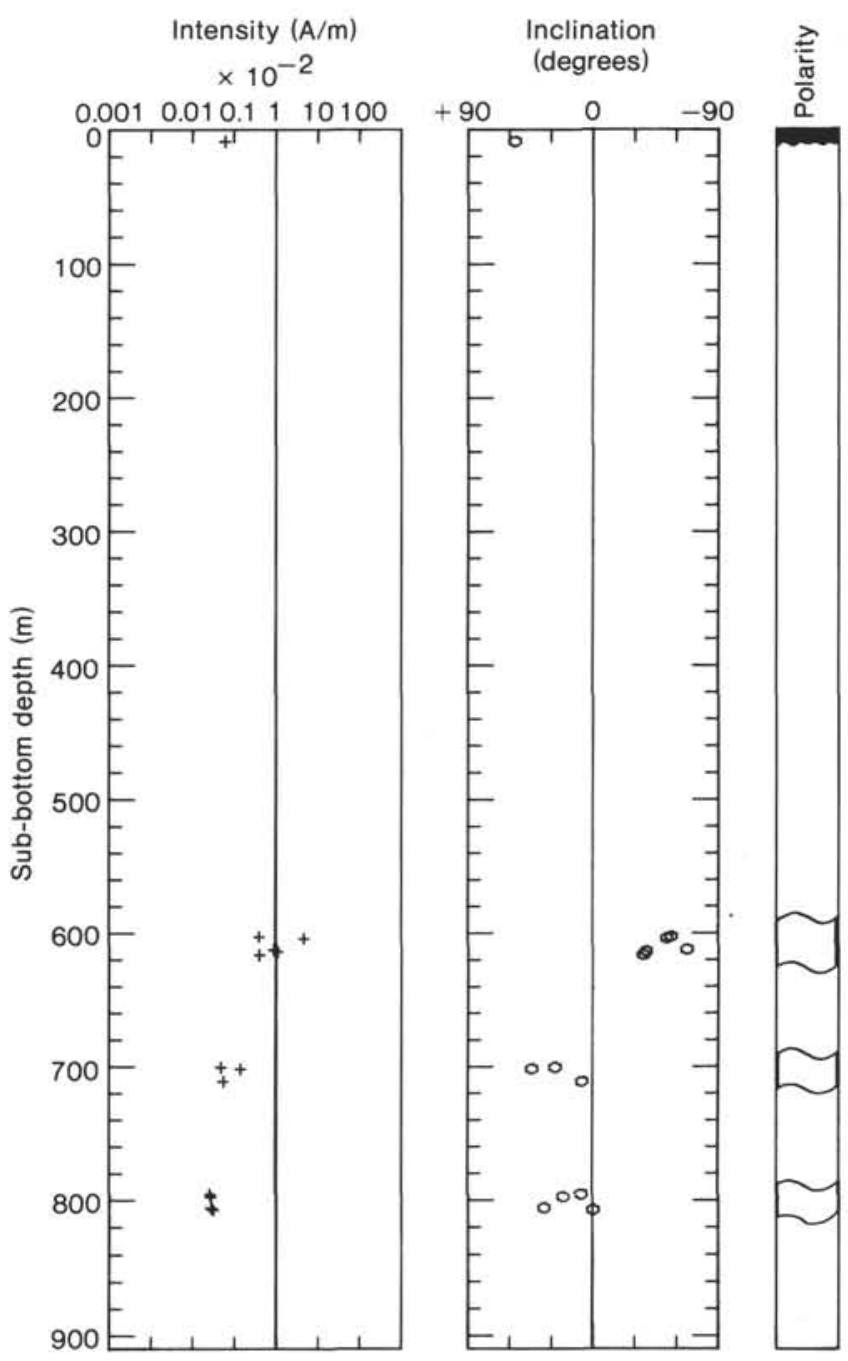

Figure 18. Magnetostratigraphy of Hole 584A. Measurements by a ring-core-type fluxgate spinner magnetometer after 15-mT AF demagnetization.

and physical properties of the sediment and the resultant contrasting responses of the sediment to tectonism.

Remagnetization increases with increasing sub-bottom depth, and most samples below $600 \mathrm{~m}$ are remagnetized (Fig. 26). This level coincides with a hiatus. Beneath this level, dip angles are high and networks of healed fractures with several millimeters of spacing are developed. Remagnetization probably occurred in the process of fracturing and filling the space of fractures, and most of the fractures were created in the normal geomagnetic field after eastward tilting of bedding planes.

The orientations of fault planes and striations on slickensides were measured from magnetic samples taken on the bedding plane. Because the drilled sediment is partially remagnetized, orientation by magnetic declination is not applicable. The direction of tilting of the bedding planes is generally eastward, except for limited horizons, so orientation of the fault planes and striations was determined with respect to bedding-dip azimuth (Fig. 27). Most of the dip azimuths of fault planes are parallel to the bedding-dip azimuth. 


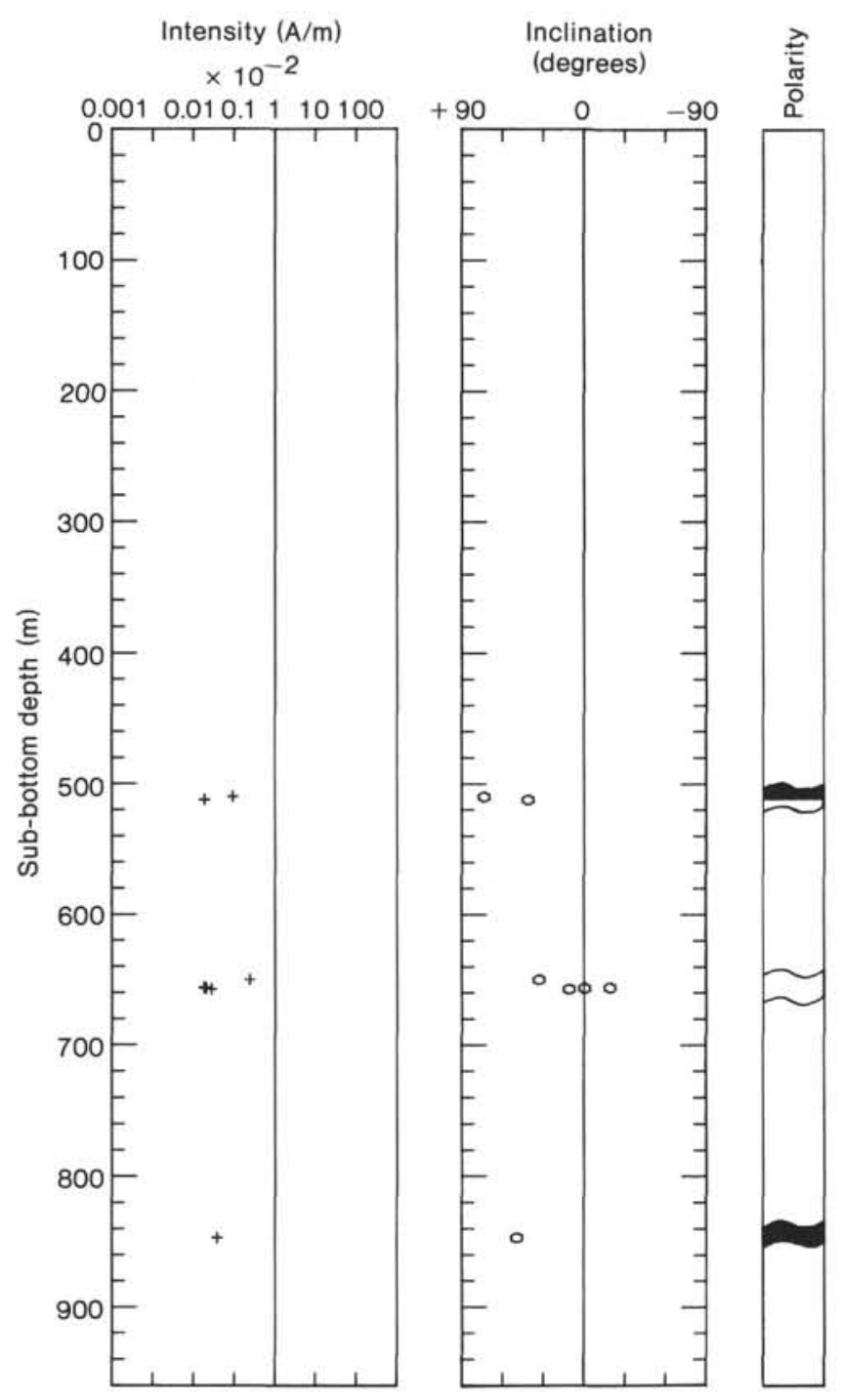

Figure 19. Magnetostratigraphy of Hole 584B. Measurements by a ringcore-type fluxgate spinner magnetometer after 15-mT AF demagnetization.

For determination of the slip direction on the fault plane, I examined the orientation of the striations and faults (Fig. 26). The mean direction and the standard deviation of the dip azimuths of dip-slip faults and strike azimuths of strike-slip faults is $32 \pm 11^{\circ}$ with respect to the dip azimuth of the bedding plane. Assuming $90^{\circ}$ (east) for the bedding-dip azimuth, the slip direction is $122 \pm 11^{\circ}$. The direction of $122^{\circ}$ is closer to the $110^{\circ}$ cited for the relative motion of the Pacific and Eurasia plates (Minster and Jordan, 1978) than to the $98^{\circ}$ for the direction of the Japan Trench.

We measured several bedding-slip faults distributed below $540 \mathrm{~m}$ sub-bottom, where the dips of bedding are steeper than $40^{\circ}$ (Fig. 26). Dewatering veinlets are common in the lower part of the hole, where they strike parallel to and vertically cut bedding planes. Because both bedding-slip faults and dewatering veinlets occur in the lower part of this hole, where the bedding planes are steep enough to be used as slip surfaces, they are proba-

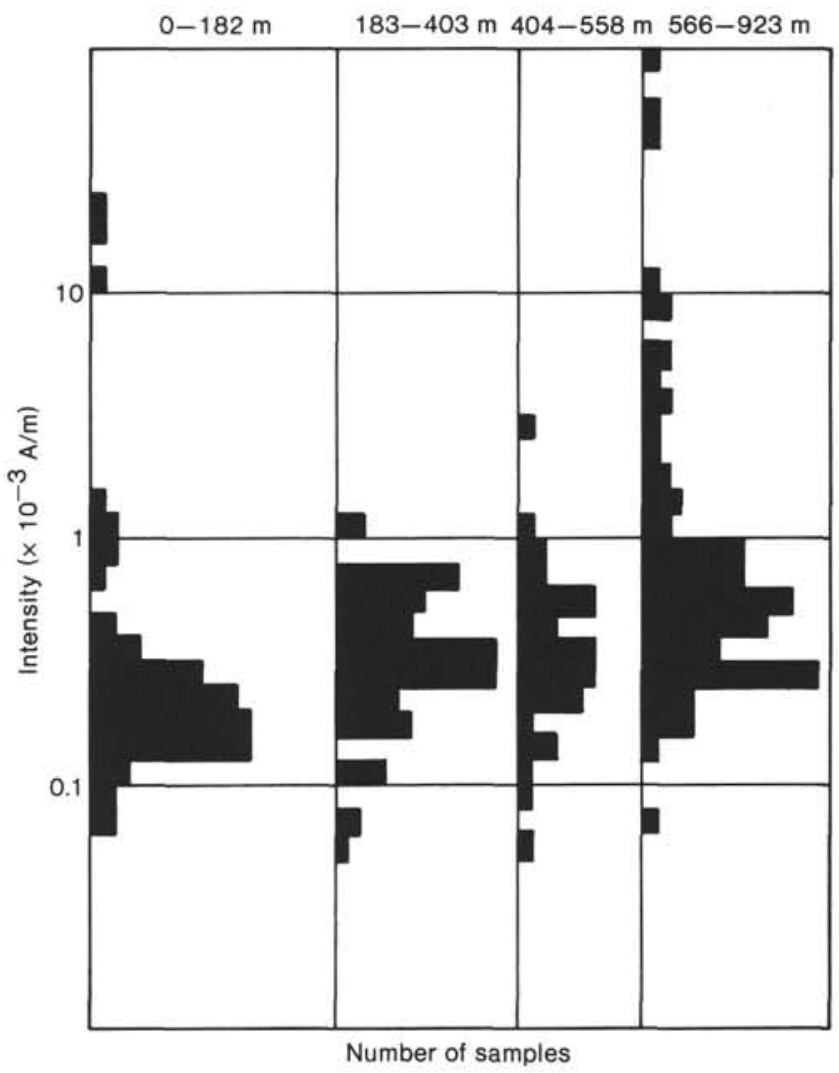

Figure 20. Frequency distribution of intensities of remanent magnetizations after 15-mT AF demagnetization for samples from Hole 584.

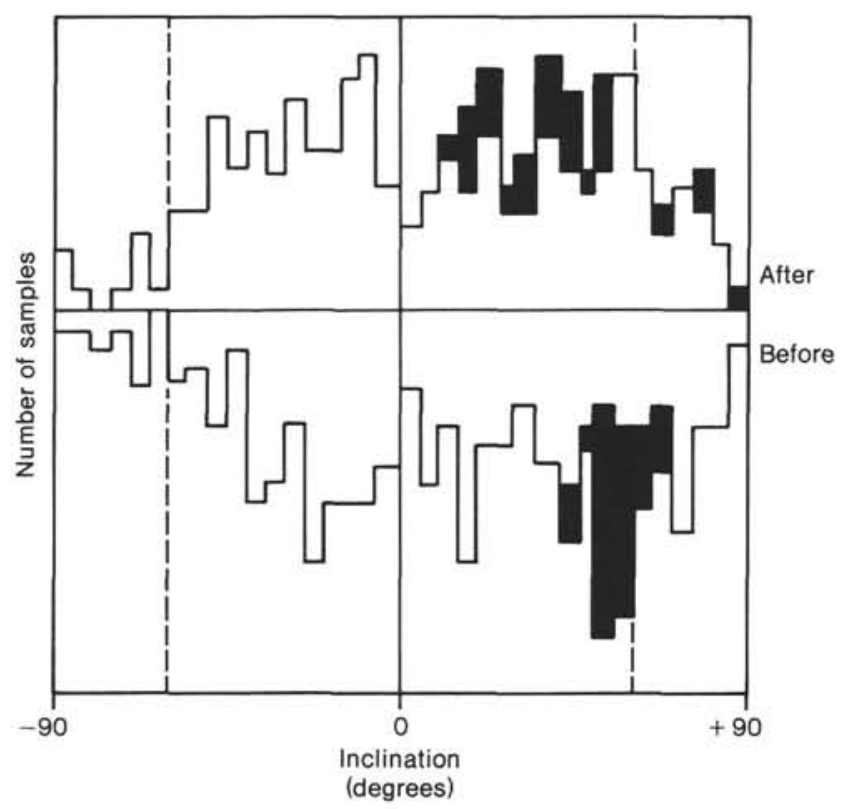

Figure 21. Frequency distribution of inclinations in Hole 584 after and before tilt correction. Dotted lines correspond to the inclinations of geocentric axial dipole field. Shaded area $=$ remagnetized sample. 


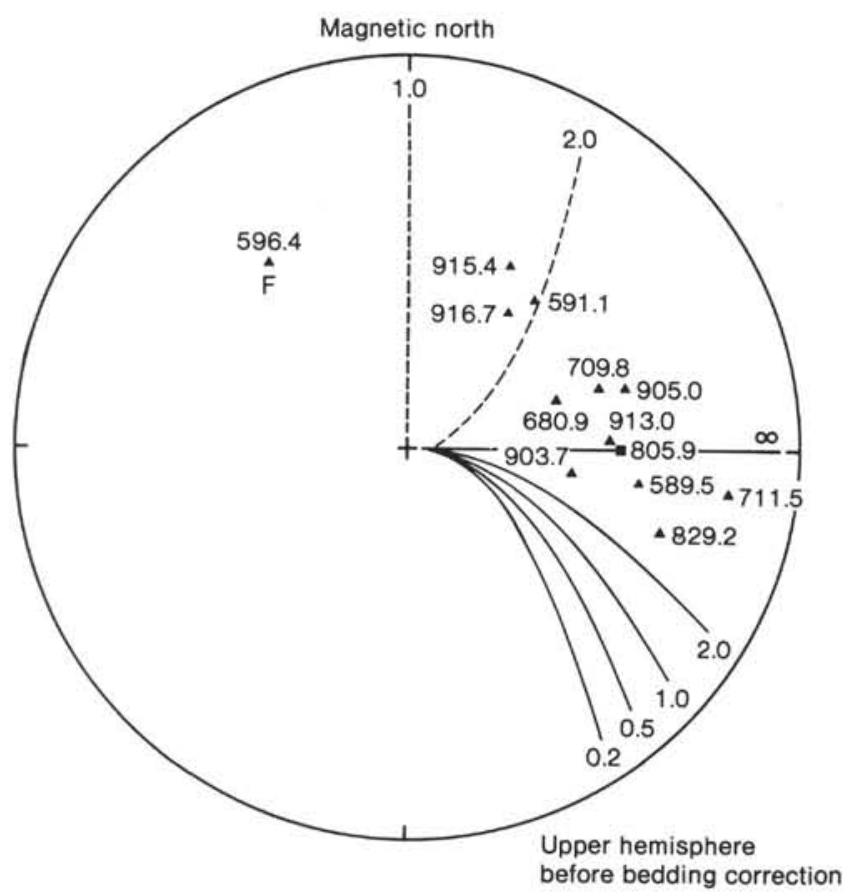

Figure 22. Poles to bedding plane of Site 584 samples remagnetized after tilting of bedding planes. Bedding-plane azimuths are adjusted for the magnetic declination. Triangle = sample from Hole 584; square $=$ sample from Hole $584 \mathrm{~A}$; dotted line $=$ iso-remagnetization line for sample originally of reversed polarity; solid line = iso-remagnetization line for sample originally of normal polarity. Numbers $0.2-1.0$ indicate ratio of remagnetized component to original component; other numbers refer to sub-bottom depth (m) at which sample was taken. $\mathbf{F}=$ sample from the interval notated as $\mathrm{F}$ in Figure 26.

bly conjugate to each other. This estimate requires that both faults and veins were created after tilting of the bedding plane.

Conjugate sets of healed faults were analyzed for determination of the principal axis of stress. Seven sets of three mutually orthogonal principal axes, both before and after bedding correction, are plotted on the stereonets (Fig. 28). Before bedding correction, maximum-stress (compressional-stress) axes are vertical, and the intermediate-stress and minimum-stress axes are horizontal; after bedding correction that relationship disappears, however, except for one data point at $680.9 \mathrm{~m}$ sub-bottom. This also indicates that the deformation represented by the healed faults occurred after tilting of the bedding planes. The average of the directions of the intermediate axes is $117 \pm 6^{\circ}$ with respect to the dip direction of the bedding plane. Because the intermediate axis is orthogonal to the directions of both tensional and compressional stress, the direction of the tensional stress is calculated as $27 \pm 6^{\circ}$ from the eastward bedding tilt and $117 \pm 6^{\circ}$ from north. The direction is consistent with the direction derived from the striations on slickensides, and with directions of plate motion.

In Holes 584A and 584B, the sedimentary section was spot-cored and 20 paleomagnetic samples were collected from the sections in which bedding planes and fault planes were oriented. In both holes, negative and shallow positive inclinations are dominant after bedding cor-

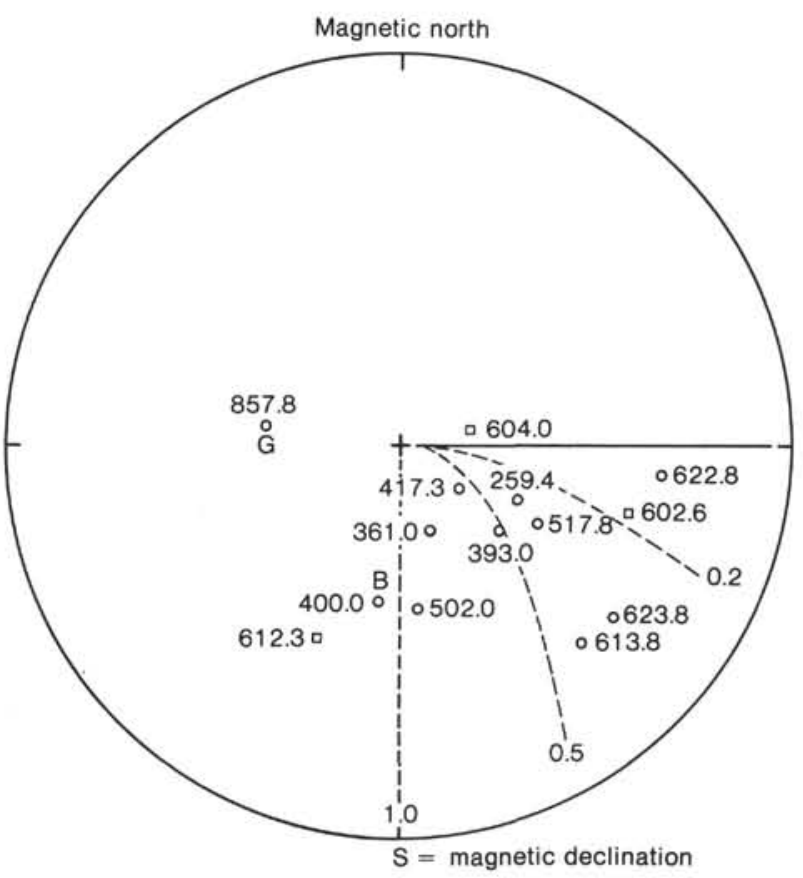

Upper hemisphere after bedding correction

Figure 23. Upper hemisphere poles to bedding planes of Site 584 samples with reversed polarity. The azimuth of the bedding plane is adjusted for the magnetic declination. Circle = sample from Hole 584 ; square $=$ sample from Hole $584 \mathrm{~A}$; dotted line = iso-remagnetization line of reversed-polarity sample. Numbers $0.2-1.0$ indicate ratio of remagnetized component to original component; other numbers refer to sub-bottom depth (m) at which sample was taken. B, G = samples from the intervals notated in Figure 26.

rection, and represent an original component of reversed polarity with a secondary remagnetized component, as in Hole 584 (Figs. 18, 19). The magnetic intensities after $15-\mathrm{mT}$ AF demagnetization are higher than $1 \times 10^{-3}$ $\mathrm{A} / \mathrm{m}$ in the middle horizons in these holes. Because intensities comparable to those in Hole 584 are also found in discrete horizons of the middle parts of Holes 584A and 584B, the horizons can be correlated between the two holes (Fig. 29). The correlation by magnetic polarity and magnetic intensity is consistent with the diatom biostratigraphic correlation (Akiba, this volume).

The distribution of poles to bedding plane is consistent with the "assumption of remagnetization" in Hole 584A (Figs. 30, 31). Therefore the directions of tilting of the bedding planes are also toward the east, except for one horizon with a normal polarity inclination. Although measurements are few for Hole 584B, their stratigraphic distribution is sporadic, and the distribution of bedding poles is scattered, the magnetic declination of remagnetized samples with shallow positive inclination before bedding correction indicates an eastward bedding dip.

The eastward tilting of bedding planes in the area of Site 584 is not consistent with the correlation of magnetobiostratigraphy, because of the $40-50^{\circ}$ dip angle of bedding and distances between the holes of 524 and $701 \mathrm{~m}$ along the dip direction. This inconsistency suggests relative uplift on the east side of this site, after the tilting of the bedding planes. Because most of the faults were cre- 

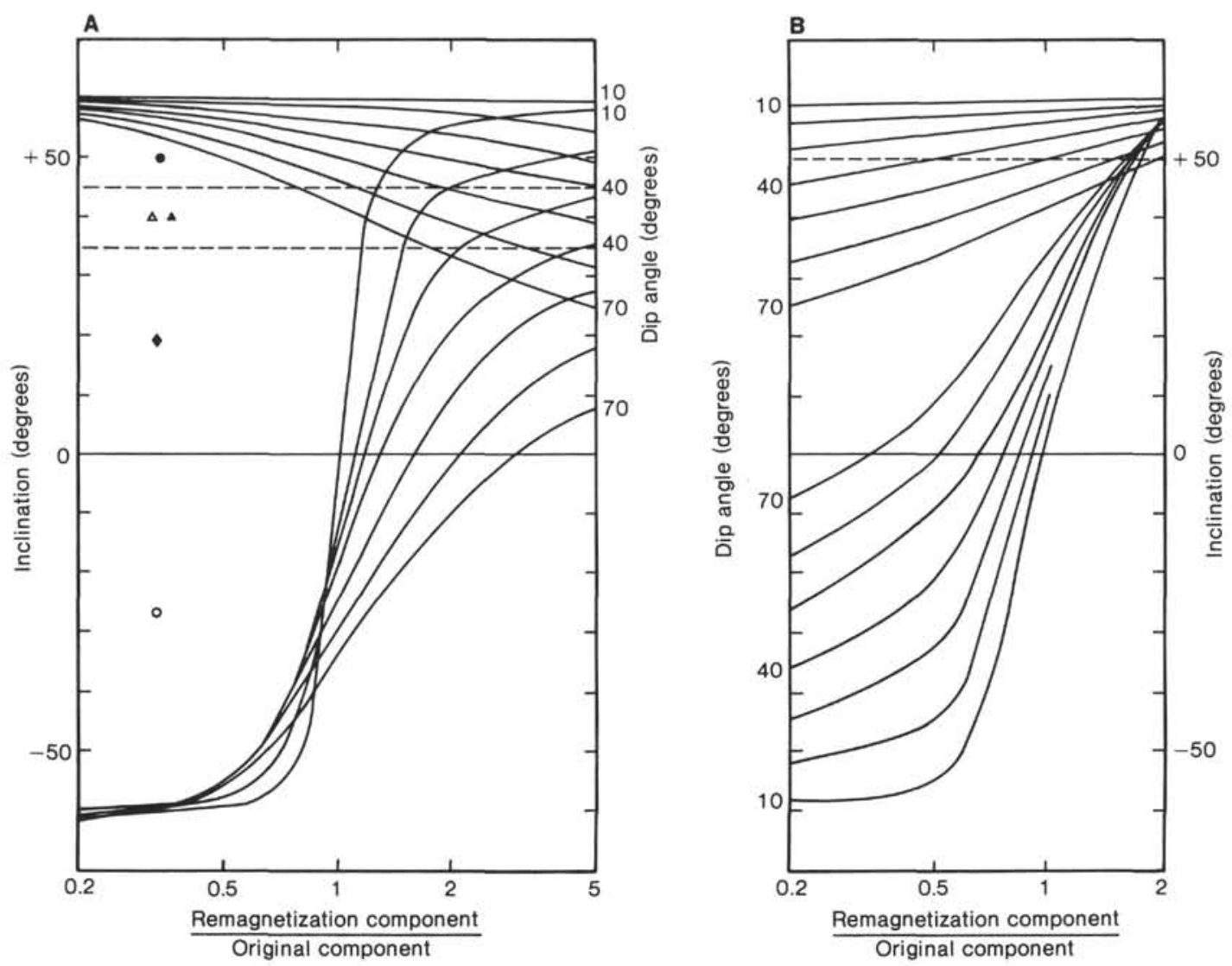

Figure 24. Relation between inclination and the ratio of the overprint component to the original component of remanent magnetization. A. After bedding correction. B. Before bedding correction. Not only does the negative inclination after bedding correction suggest reversed polarity, but the shallow positive inclination also suggests reversed polarity. Symbols in A are the same as those in Figure 25.

ated after bedding tilt, the faulting should contribute to the uplift of the east side. The easterly uplift is consistent with the existence of a midslope bench, in which seismic reflectors show the sediment fill tilted toward the west (Kagami et al., this volume).

The direction of bedding-plane tilting is perpendicular to the strike of the Japan Trench axis $\left(8^{\circ}\right)$ and the direction of fault slip $\left(120^{\circ}\right)$, and nearly parallel to the relative motion of the Pacific and the Eurasia plates $\left(110^{\circ}\right)$. These directions suggest that the bedding-plane tilt is controlled by the shape of the outer edge of the continental plate, and that the fault motion within the sediments is controlled by the relative plate motion. This faulting should create the trench-slope break, midslope high, midslope bench, and midslope terrace.

\section{DISCUSSION AND CONCLUSION}

On the basis of paleomagnetic measurements of sediment samples, the magnetostratigraphy at Sites 582, 583, and 584 in the Nankai Trough and the Japan Trench is established and abrupt changes in the sediment accumulation rate are documented. Changes in the sediment accumulation rates correspond to tectonic cycles in the geologic evolution of the Japanese island arc. The development of an accretionary prism along the Nankai Trough is directly related to the supply of turbidites in the limited time interval since the collision between the Honshu and Izu arcs, northeast of the drilled sites. The drilled sediments are faulted and folded. The drag folds associated with faults, the stress field for the conjugate sets of faults, and the striations on slickensides indicate the direction of plate motion.

In the Japan Trench, tectonic disturbances took place in two steps: first, tilting of bedding planes along the trench axis, and second, faulting. The first step corresponds to the deepening of the floor of the Japan Trench, the second step to the uplift of the midslope, which created the midslope terraces and benches, probably in relation to accretionary processes. The remanent magnetization of the sediments cored from the Japan Trench was remagnetized during the fracturing and healing processes, after tilting of the bedding planes. Because this kind of remagnetization is not acquired by chemical changes in the magnetic minerals, it is difficult to eliminate the secondary remagnetized component by the ordinary techniques of demagnetization. Assuming that remagnetization has occured, I determined the original magnetic polarity and the direction of bedding-plane tilt. The original magnetic polarities, supplemented by diatom biostratigraphy, form the basis for magnetostratigraphic correlation from the Gauss Epoch to magnetic polarity Epoch 17. The general direction of bedding dip is eastward, although several limited horizons dip north and westward. 
A

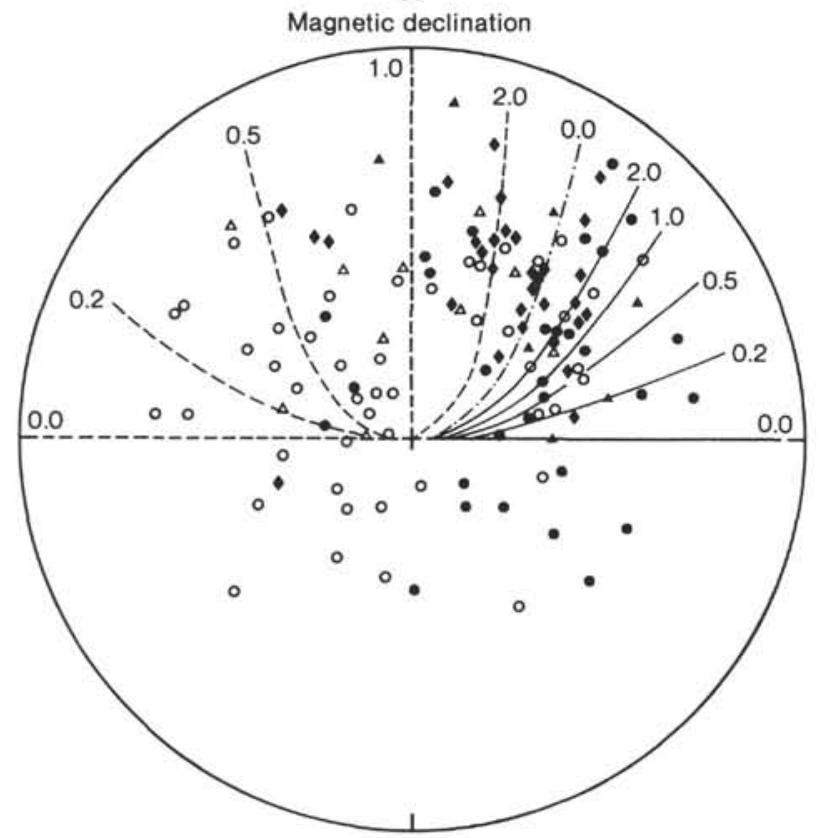

--- Iso-remagnetization line for sample originally of reversed polarity.

- Iso-remagnetization line for sample originally of normal polarity. Inclination after bedding correction:
B

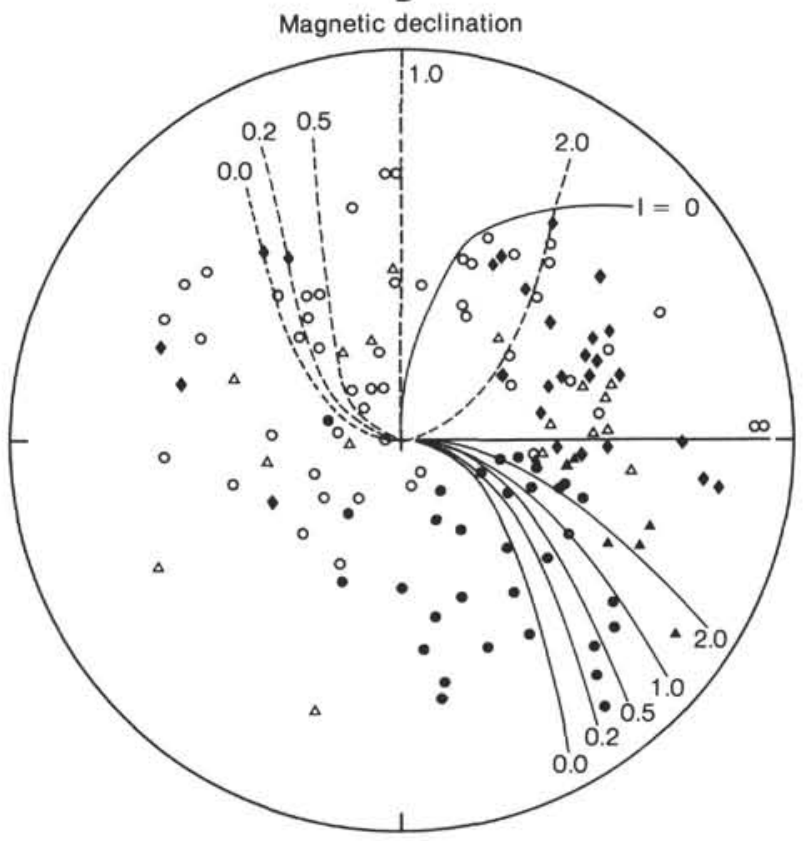

- Steeper than $+45^{\circ}$ (originally normal polarity)

$\Delta+35$ to $\sim+45^{\circ}$ (originally normal polarity)

$\Delta+35$ to $\sim+45^{\circ}$ (originally reversed polarity)

- 0 to $\sim+35^{\circ}$ (originally reversed polarity)

- Negative (originally reversed polarity)

Figure 25. Poles to bedding plane of all samples from Hole 584 on upper hemisphere. The direction of tilting of bedding plane was calculated on the basis of measured magnetic declination (A) after and (B) before bedding correction-the calculated direction is counted from magnetic north for normal-polarity samples and from magnetic south for reversed samples. If there is no component of overprint and the tilt direction of bedding plane is toward east, the pole should be concentrated on $90^{\circ}$ for normal samples and $270^{\circ}$ for reversed samples. Numbers indicate ratio of remagnetized component to original component.

\section{ACKNOWLEDGMENTS}

I wish to express my gratitude to Hisao Nakagawa of Tohoku University for valuable comments, discussions, and review of the manuscript. Asahiko Taira of Tokyo University collected samples for these paleomagnetic measurements during the Leg $87 \mathrm{~A}$ cruise and also discussed many aspects of the sedimentology and tectonics. Fumio Akiba of the Japan Petroleum Exploration Co., Ltd. gave paleontologic and biostratigraphic suggestions, for which I am very grateful. I also express my thanks to Hajimu Kinoshita of Chiba University, Kazuto Kodama of Kochi University, and William T. Coulbourn of the University of Hawaii for their reviews.

\section{REFERENCES}

Gartner, S., and Emiliani, C., 1976. Nannofossil biostratigraphy and climatic stages of Pleistocene Brunhes Epoch. Am. Assoc. Pet. Geol. Bull., 60:1562-1564.

Ingle, J. C., Jr., Karig, D. E., and Shipboard Scientific Party, 1975. Site 297. In Karig, D. E., Ingle, J. C., Jr., et al., Init. Repts. DSDP, 31: Washington (U.S. Govt. Printing Office), 275-316.

Koizumi, I., and Kanaya, T., 1976. Late Cenozoic marine diatom sequence from the Choshi district, Pacific coast, central Japan. In Takayanagi, Y., and Siato, T. (Eds.), Progress in Micropaleontology: New York (Micropaleontology Press), pp. 144-159.

Koyama, M., and Niitsuma, N., 1983. Ring-core-type flux-gate spinner magnetometer and current-regulated three-axial alternating field demagnetizer. Geosci. Rep. Shizuoka Univ., 8:49-61.

Mankinen, E. A., Donnelly, J. M., and Grommé, C. S., 1978. Geomagnetic polarity event recorded at 1.1 m.y.B.P. on Cobb Mountain, Clear Lake volcanic field, California. Geology, 6:653-656.
Minster, J. B., and Jordan, T. H., 1978. Present-day plate motions. J. Geophys. Res., 83:5331-5354.

1979. Rotation vectors for the Philippine and Rivera plates. EOS, Trans. Am. Geophys. Union, 60:958.

Nakagawa, H., Niitsuma, N., Oda, M., and Kitazato, H., 1982. PlioPleistocene stratigraphy of Kakegawa area, central Japan. In Itihara, M., and Kuwano, Y. (Eds.), Third Rept. on the PliocenePleistocene Boundary in Japan: Osaka (IGCP no. 41, Japanese National Working Group), pp. 51-58.

Nakaseko, K., (Ed.), 1984. Geologic Survey of the Submarine Strata at the Kansai International Airport in Osaka Bay, Central Japan: Osaka (Calamity Sci. Inst.).

Niitsuma, N., 1971. Detailed studies on the sediments recording the Matuyama-Brunhes geomagnetic reversal. Tohoku Univ. Sci. Rep. 2nd Ser. (Geol.), 43:1-39.

1977. Zone-magnetization model and depth lag of NRM in deep-sea sediments. Rock Mag. Paleogeophys., 4:65-71.

Niitsuma, N., and Akiba, F., in press. Neogene tectonic evolution and plate subduction in the Japanese island arcs. In Nasu, N., Uyeda, S., and Kagami, H. (Eds.), Formation of Active Ocean Margins: Tokyo (Terrapub.).

Niitsuma, N., and Ku, T. L., 1977. What happened to the biosphere during the Earth's magnetic reversals? Kagaku, 47:671-678.

Wollin, G., Ericson, D. B., Ryan, W. B. F., and Foster, J. H., 1971. Magnetism of the earth and climatic changes. Earth Planet. Sci. Lett., 12:175-183.

Date of Initial Receipt: 2 July 1984 Date of Acceptance: 10 May 1985 


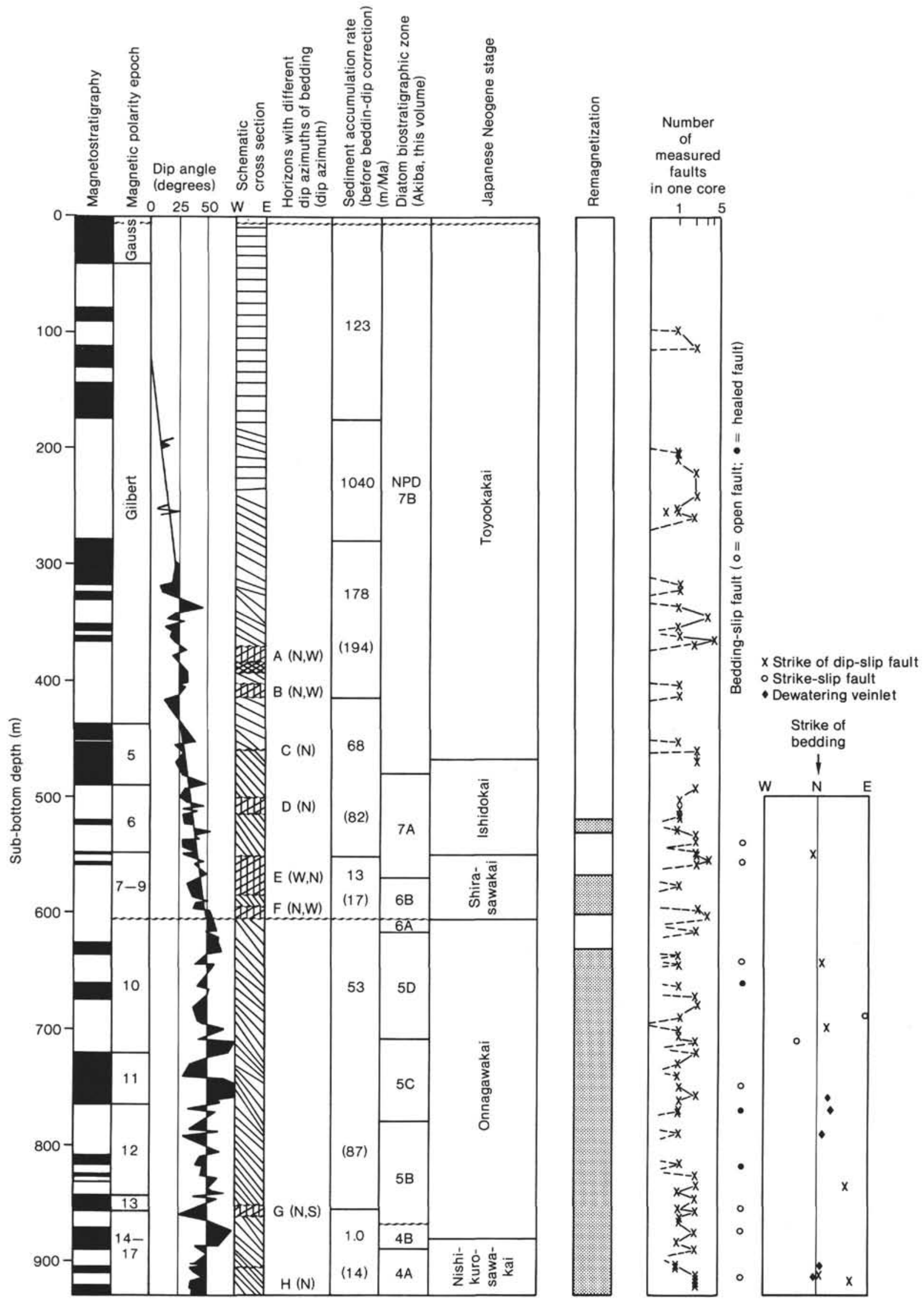

Figure 26. Magnetostratigraphic synthesis, Hole 584. 


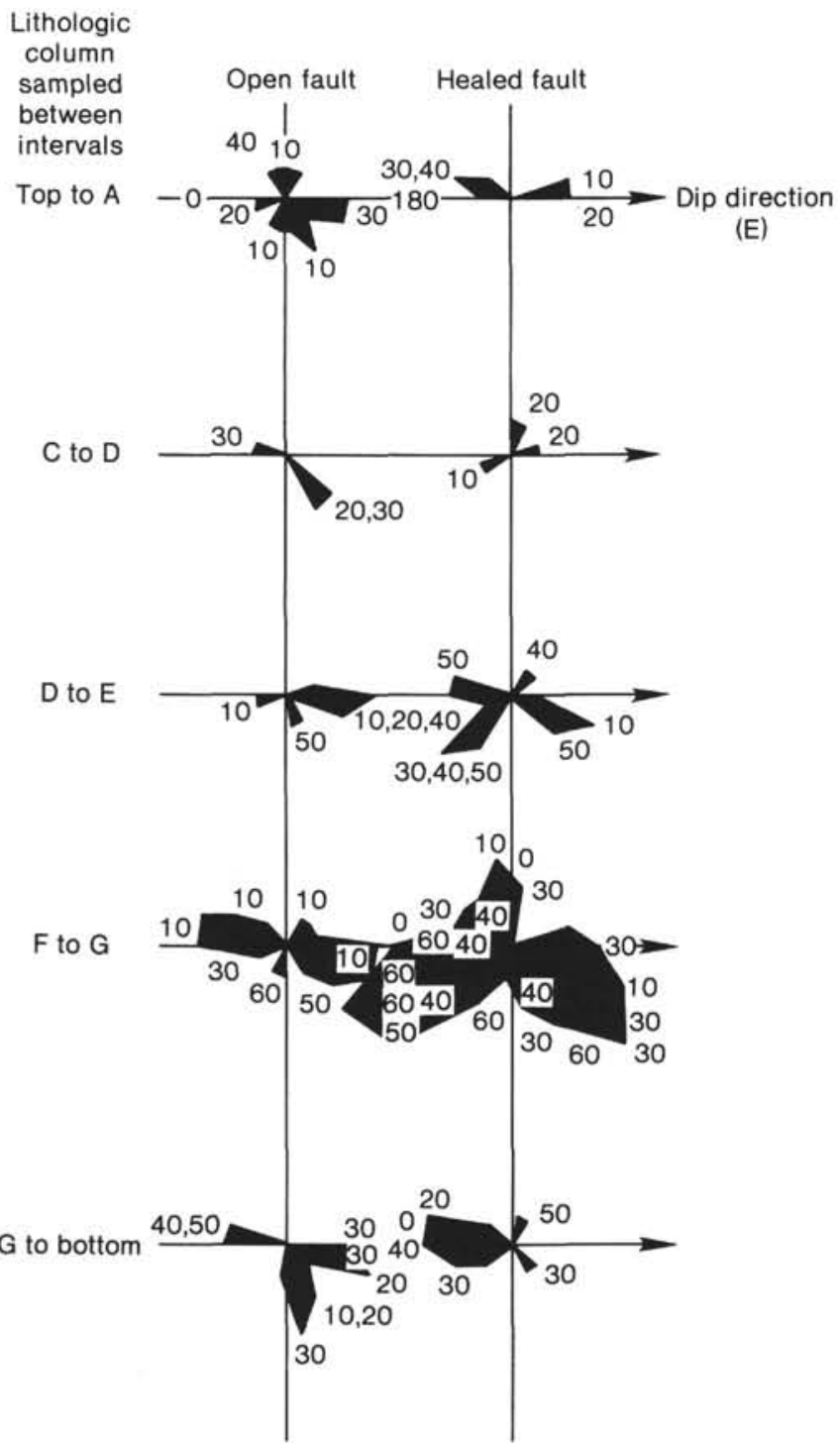

Figure 27. Rose diagrams of the dip azimuth of healed and open fault planes in the interval separated by Horizons A-G (see Fig. 26), where dip azimuths of bedding planes are not eastward. (There are no data in intervals $\mathrm{A}$ to $\mathrm{B}, \mathrm{B}$ to $\mathrm{C}$, and $\mathrm{E}$ to $\mathrm{F}$.) 


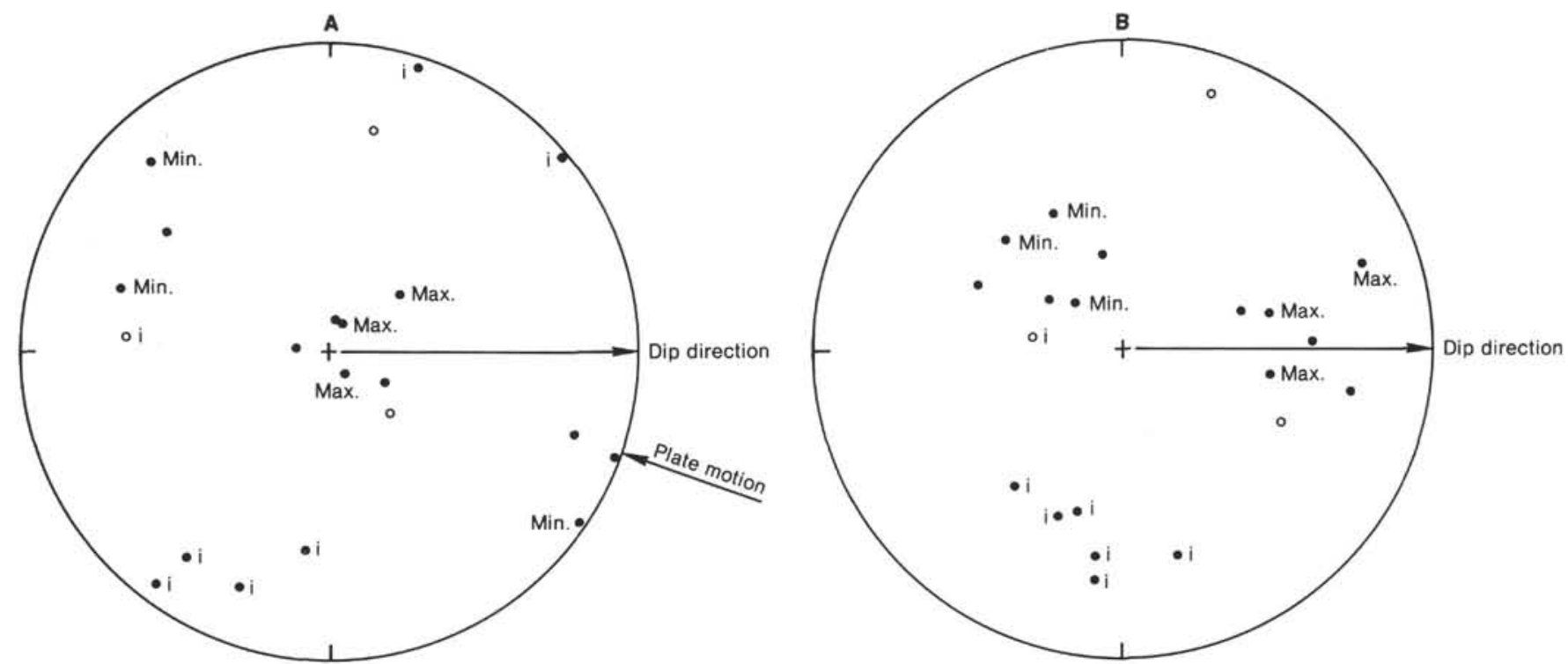

Figure 28. Principal orthogonal axes of stress pattern in Hole 584 on lower hemisphere, (A) before and (B) after bedding correction. Max $=$ maximum-stress axis; $\mathrm{i}=$ intermediate axis; $\min =$ minimum-stress axis; unlabeled $=$ undefined axis ( $\max$. or min.). Filled circles represent these sub-bottom levels $(\mathrm{m}): 532.0,604.1,671.9,759.8,817.8,827.2$. Open circles represent $671.2 \mathrm{~m}$ sub-bottom. 


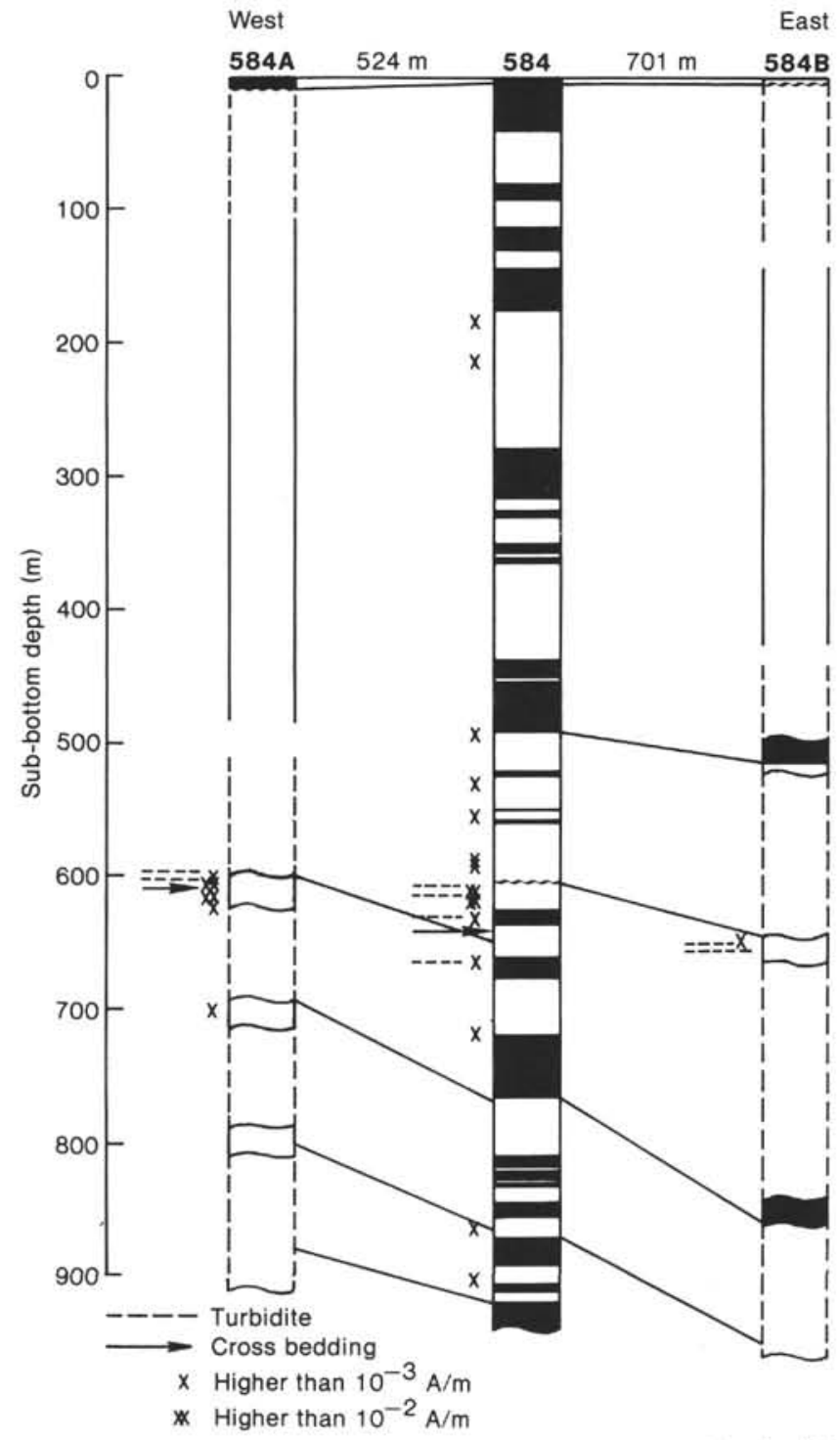

Figure 29. Magnetic reversal sequence for Hole 584 correlated with Holes $584 \mathrm{~A}$ and $584 \mathrm{~B}$ by magnetic polarity and magnetic intensity, supplemented by diatom biostratigraphy. 
A

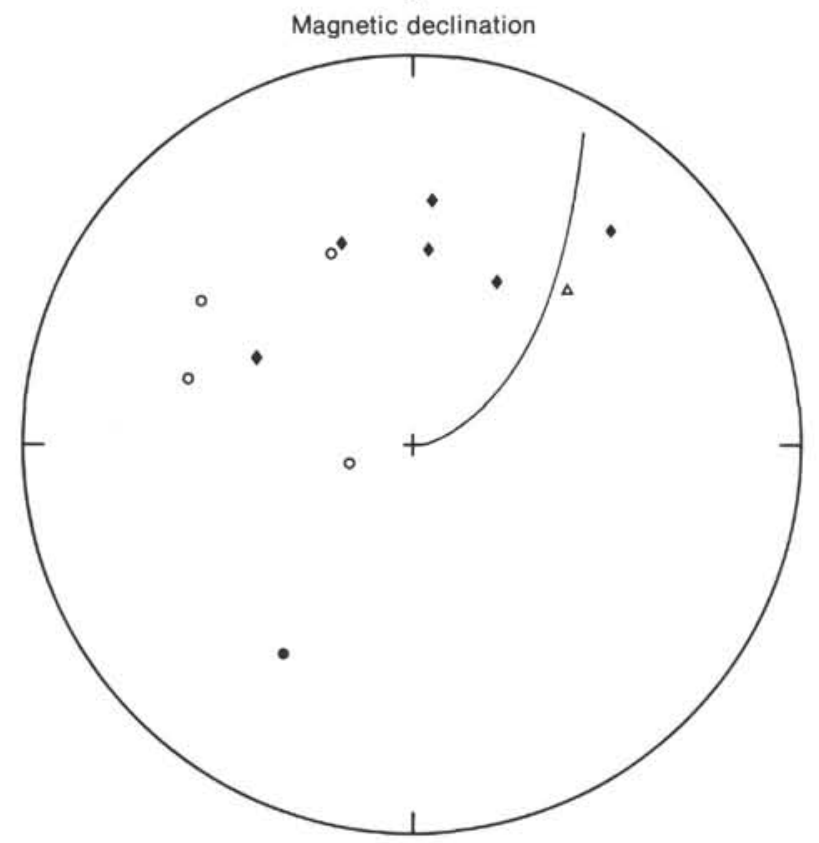

Remagnetized sample with magnetic inclination of $0^{\circ}$

Completely remagnetized sample after bedding tilt

Sample without remagnetized component
Magnetic declination

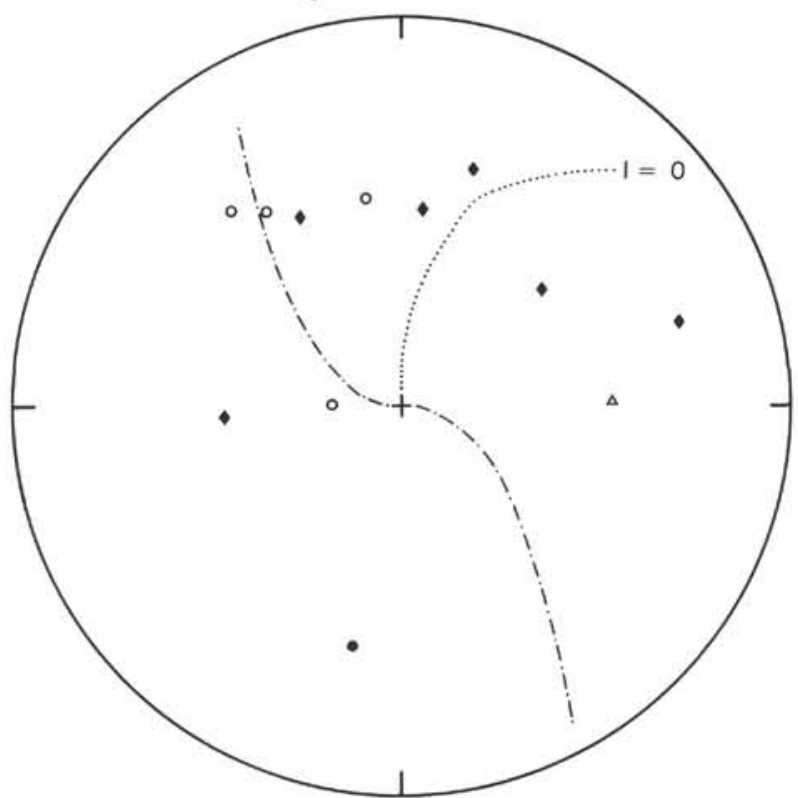

Inclination after bedding correction:

- Steeper than $+45^{\circ}$ (originally normal polarity)

$\Delta \quad+35$ to $\sim+45^{\circ}$ (originally reversed polarity)

- 0 to $\sim 35^{\circ}$ (originally reversed polarity)

- Negative (originally reversed polarity)

Figure 30. Poles to bedding plane of all samples from Hole 584A on upper hemisphere. A. After bedding correction. B. Before bedding correction.

A

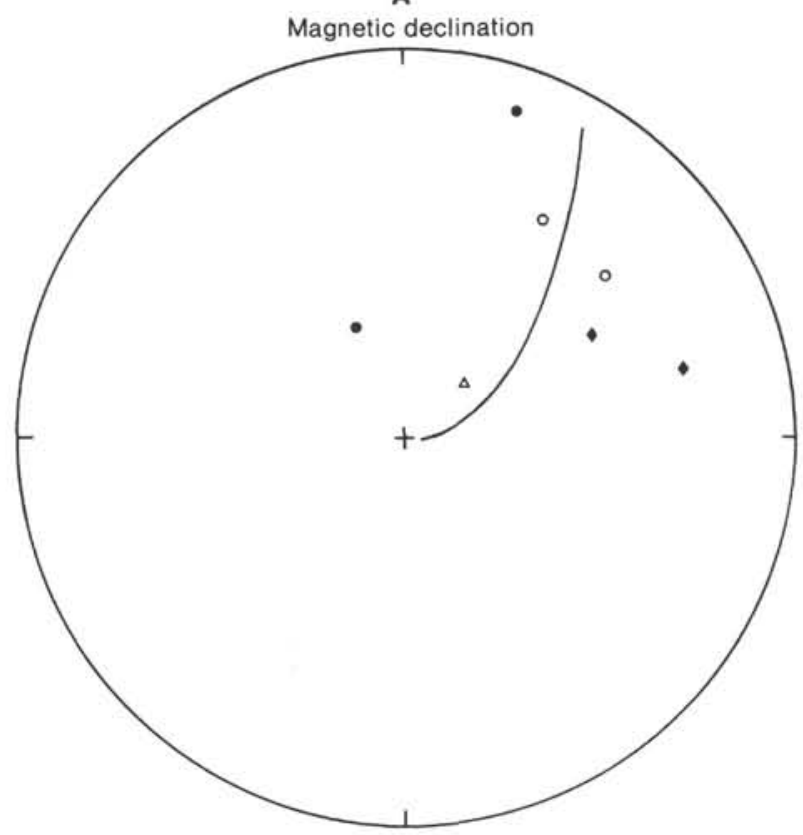

-- - Remagnetized sample with magnetic inclination of $0^{\circ}$ Completely remagnetized sample after bedding tilt ..._- Sample without remagnetized component

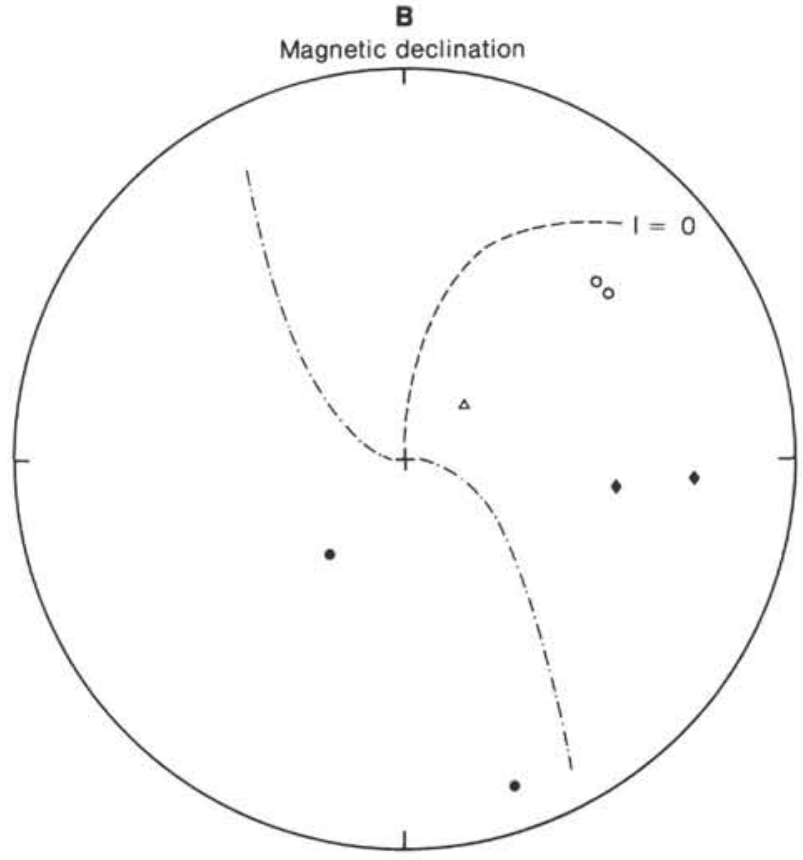

Inclination after bedding correction:

- Steeper than $+45^{\circ}$ (originally normal polarity)

$\Delta \quad+35$ to $\sim+45^{\circ}$ (originally reversed polarity)

- 0 to $\sim+35^{\circ}$ (originally reversed polarity)

- Negative (originally reversed polarity)

Figure 31. Poles to bedding plane of all samples from Hole 584B on upper hemisphere. A. After bedding correction. B. Before bedding correction. 